\title{
CRESCIMENTO E ABSORÇÃO DE NUTRIENTES PELA ALFACE CULTIVADA EM FLUXO LAMINAR DE SOLUÇÃO
}

\author{
VANDERLEI NESTOR KOEFENDER \\ Engenheiro Agrônomo
}

Orientador: Prof. Dr. Quirino Augusto de Camargo Carmello

Dissertação apresentada à Escola Superior de Agricultura "Luiz de Queiroz", da Universidade de São Paulo, para obtenção do título de Mestre em Agronomia, Área de Concentração: Solos e Nutrição de Plantas.

P I R A C I C A B A

Estado de São Paulo - Brasil

Outubro - 1996 
Dados Internacionais de Catalogação na Publicação (CIP)

DIVISĀO DE BIBLIOTECA E DOCUMENTAÇĀO - Campus “Luiz de Queiroz"/USP

Koefender, Vanderlei Nestor

Crescimento e absorçăo de nutrientes pela alface cultivada em fluxo laminar de de soluç̧o / Vanderlei Nestor Koefender. - - Piracicaba, 1996.

85 p. : II.

Dissertação (mestrado) - - Escola Superior de Agricultura Luiz de Queiroz, 1996.

Bibliografia.

1. Alface - Nutrição 2. Fluxo laminar de solução 3. HIdroponia I. Título

CDD 635.52

631.585 


\title{
CRESCIMENTO E ABSORÇÃO DE NUTRIENTES PELA ALFACE CULTIVADA EM FLUXO LAMINAR DE SOLUÇÃO
}

\author{
VANDERLEI NESTOR KOEFENDER
}

Aprovada em : 26.11 .1996

Comissão julgadora:

Prof. Dr. Quirino Augusto de Camargo Carmello ESALQ/USP

Prof. Dr. Francisco Antonio Monteiro

ESALQ/USP

PqC. Dr. Pedro Roberto Furlani

IAC/SAA

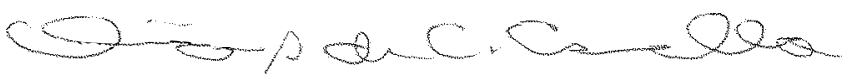

Prof. Dr. Quirino Augusto de Camargo Carmello

Orientador 
Ao Criador e meus guias por me acompanharem em tudo o que faço, Agradeço.

Aos meus pais, Vilmut Irineu e Reni e ao meu avô, Oscar Antônio pelo carinho, confiança e incentivo, Ofereço.

Para minha irmã Sirlei, pelo carinho e pelo constante incentivo para perseguir meus sonhos, Dedico. 


\section{AGRADECIMENTOS}

Ao Prof. Dr. Quirino Augusto de Camargo Carmello pela amizade, orientação e apoio que contribuíram para a realização desse trabalho.

Ao Setor de Nutrição Mineral de Plantas do Departamento de Química da Escola Superior de Agricultura "Luiz de Queiroz"/USP pela infra-estrutura e pelo apoio durante a realização desse trabalho.

À Coordenação de Aperfeiçoamento de Pessoal de Nível Superior (CAPES) pelo apoio financeiro através da Bolsa concedida.

À Comissão de Apoio à Vila Estudantil (CAVE) pela moradia concedida.

Aos funcionários do Setor de Nutrição Mineral de Plantas Edinéia Cristina S. Mondoni, Fernando Éder Ré, Lourdes A. Dário de González, Lúcia Helena S. Pavan Forti, Nivanda Maria de Moura, Mirtes Ventura Sesso e Sueli Maria Amaral Campos Bovi, pela amizade e pelo auxílio prestado na condução do estudo e na realização das análises químicas.

A bibliotecária Kátia M. Andrade Ferraz pela correção das referências bibliográficas.

Ao Prof. Dr. Carlos Tadeu dos Santos pelas informações concedidas para a realização das análises estatísticas.

Ao Prof. Dr. Francisco Antônio Monteiro pela amizade e auxílio prestado na confecção do "summary".

Ao Eng ${ }^{o}$. Agr ${ }^{o}$. Alexandre Ferreira Develey pela amizade e pela doação das mudas de alface.

Ao colega Fábio Álvares de Oliveira pela amizade e pelo grande auxílio prestado na fase inicial do trabalho. 
Aos colegas da sala de Pós-graduação do setor de Nutrição Mineral de Plantas da ESALQ pela amizade, pelas sugestões no estudo e pelas experiências de vida transmitidas.

Aos colegas da Vila Estudantil da Pós-graduação da ESALQ pelo companheirismo, pelo convívio amigável e pela troca de experiências.

A todas as pessoas que não foram mencionadas mas que auxiliaram de alguma forma para que esse trabalho pudesse ser realizado com êxito. 


\section{SUMÁRIO}

página

RESUMO ........................................................................... vill

SUMMARY ...........................................................................

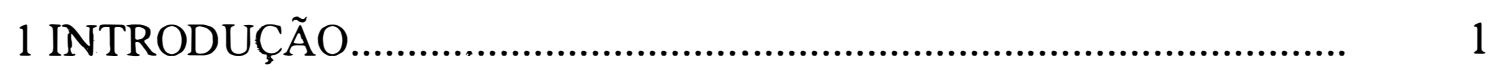

2 REVISÃO DE LITERATURA........................................................ 3

2.1. Técnica do fluxo laminar de solução ("NFT").................................. 3

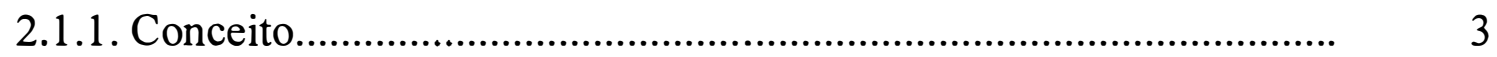

2.1.2. Vantagens e limitações........................................................... 4

2.2. Solução nutritiva em "NFT" .......................................................... 6

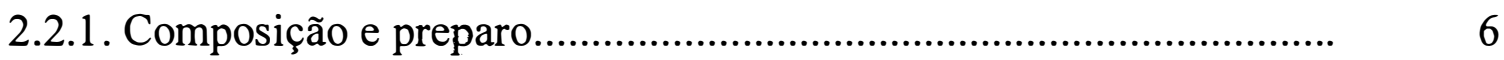

2.2.2. Uso e manejo....................................................................... 8

2.2.2.1. Condutividade elétrica (CE) .............................................. 11

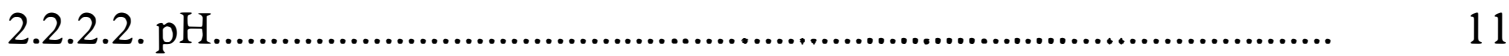

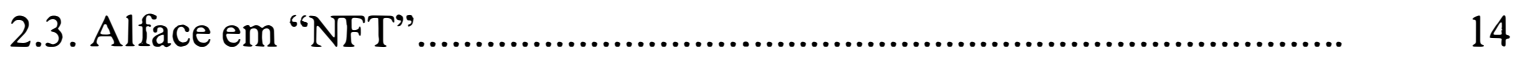

2.3.1. Absorção de nutrientes e produção............................................... 14

2.3.2. CE e $\mathrm{pH}$........................................................................... 16

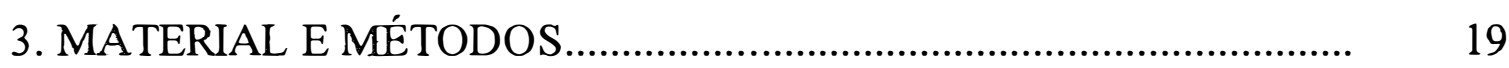

3.1. Condições experimentais............................................................ 19

3.2. Delineamento experimental, tratamentos e condução do experimento 20

3.3. Amostragens e determinações.................................................... 24

3.4. Análises estatísticas............................................................... 25

4. RESULTADOS E DISCUSSÃO.................................................... 26

4.1. Solução nutritiva........................................................................ 26

4.1.1. Consumo........................................................................... 26

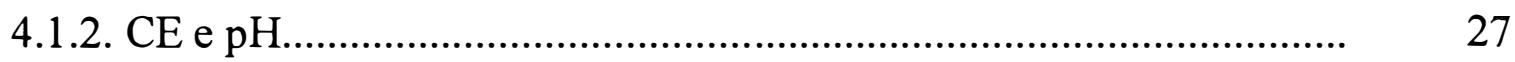


página

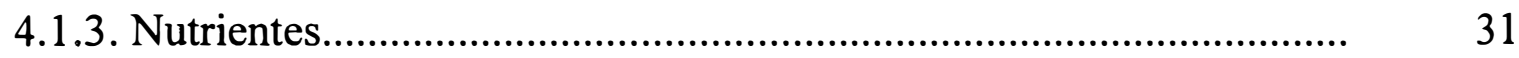

4.1.3.1. Macronutirentes....................................................................... 32

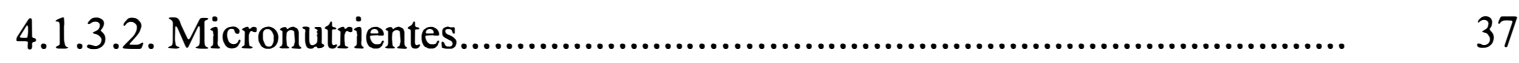

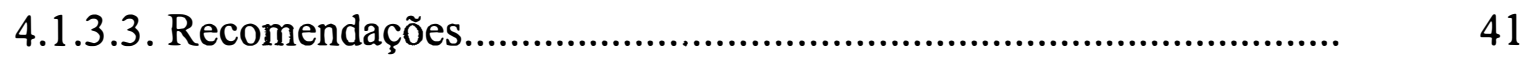

4.2. Alface

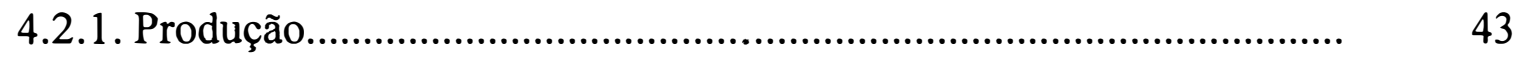

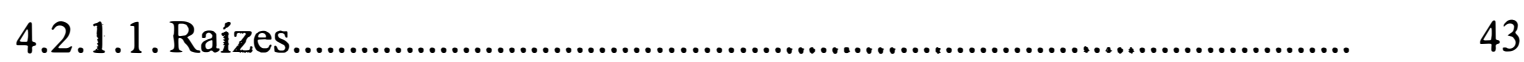

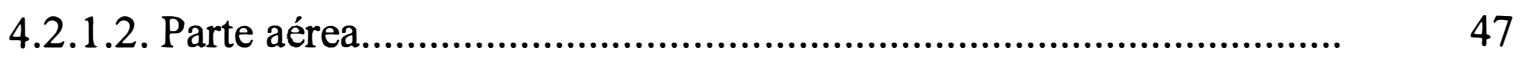

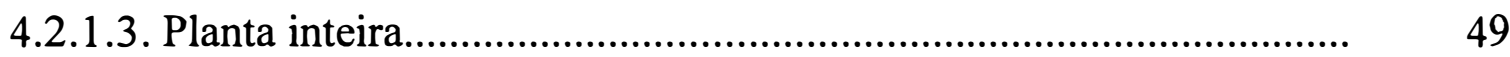

4.2.2. Concentração e absorção de nutrientes............................................... 53

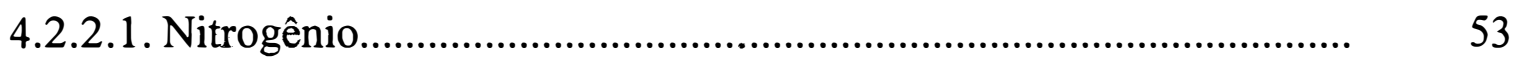

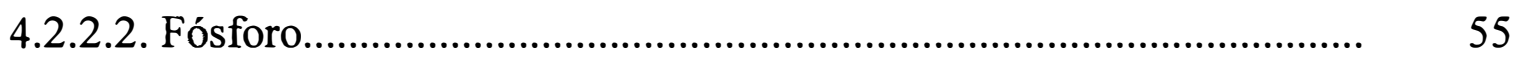

4.2.2 3.Potássio ...................................................................................... 57

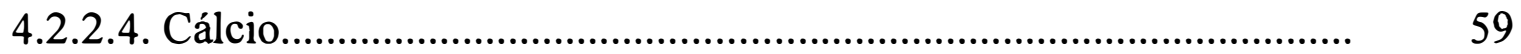

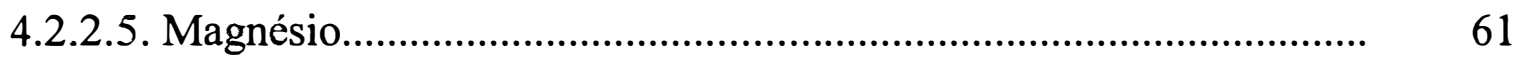

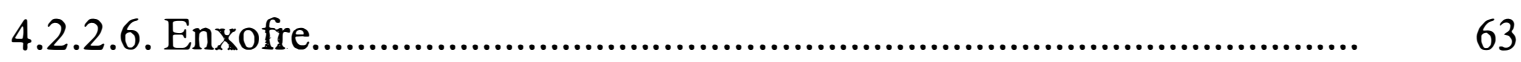

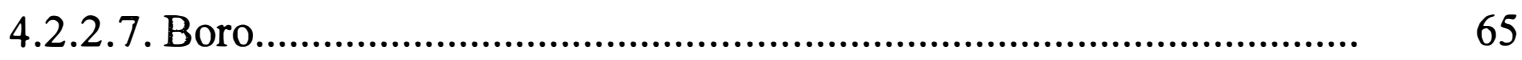

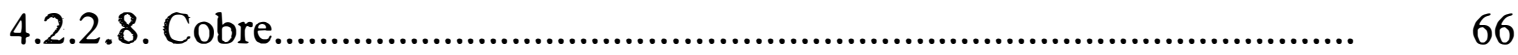

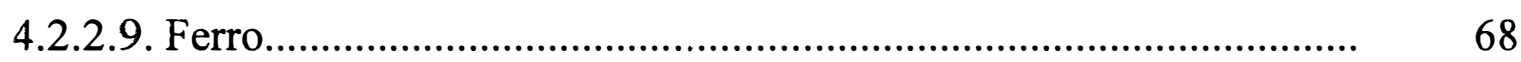

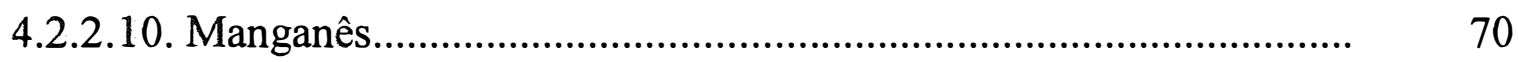

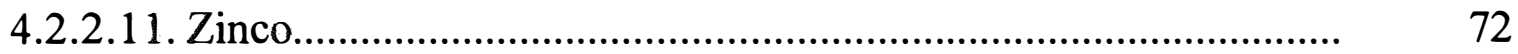

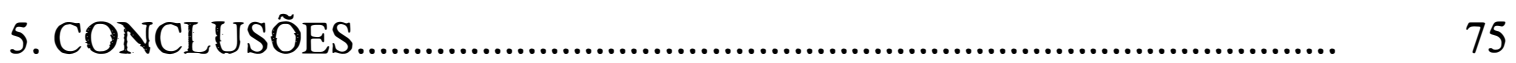

REFERÊNCIAS BIBLIOGRÁFICAS.................................................. 76

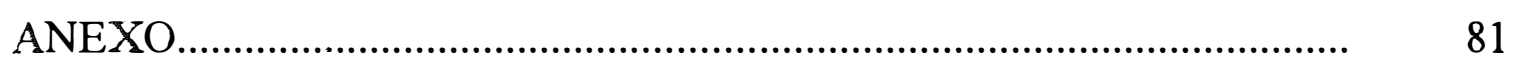




\title{
CRESCIMENTO E ABSORÇÃO DE NUTRIENTES PELA ALFACE CULTIVADA EM FLUXO LAMINAR DE SOLUÇÃO
}

\author{
Autor: VANDERLEI NESTOR KOEFENDER \\ Orientador: Prof. Dr. QUIRINO AUGUSTO DE CAMARGO CARMELLO
}

\section{RESUMO}

A produção de hortaliças pela técnica do fluxo laminar de solução ("NFT") é prática comum nas nações desenvolvidas (EUA, Austrália e países da Europa). No Brasil, os cultivos hidropônicos podem ser encontrados nos cinturões verdes de algumas capitais e em algumas cidades do interior, sendo a alface comumente a espécie mais cultivada. Muitas dúvidas existem, porém, em relação ao seu cultivo, principalmente no que se refere ao seu crescimento e absorção de nutrientes em função do manejo das soluções nutritivas.

Assim sendo, a alface ( Lactuca sativa L.) cv. Verônica foi produzida em "NFT", sob três formas de manejo da solução nutritiva pós-transplante: reposição diária do volume com água (RVA); reposição diária do volume com solução nutritiva (RVS) e renovação total diária da solução nutritiva (RTD), para comparar os efeitos desses manejos sobre a produção de material fresco (MF) e seco (MS) da alface, sua composição e quantidades de nutrientes absorvidas. Além disso, verificou-se o comportamento do $\mathrm{pH}$, da condutividade elétrica (CE), da concentração de nutrientes e do volume consumido nas soluções manejadas, 
durante o ciclo da alface ( 30 dias pós-transplante). O delineamento experimental utilizado foi de blocos ao acaso com 10 repetições.

As soluções nutritivas foram analisadas diariamente, enquanto que as plantas foram analisadas aos $10,15,20,25$ e 30 dias pós-transplante (dpt) constituindo-se assim em parcelas subdivididas no tempo.

Os resultados permitiram concluir que os manejos das soluções nutritivas afetaram a relação produção de material fresco de raízes/ produção de material fresco da parte aérea da alface, refletindo-se em maior consumo de solução nutritiva quando esse valor foi menor. A produção de material fresco da planta inteira de alface não foi afetada pelo manejo da solução, enquanto a produção de material seco foi afetada. $\mathrm{O}$ pH, a $\mathrm{CE}$ e a concentração de nutrientes na solução foram diferentes nas várias formas de manejo.

As concentrações de enxofre, boro, cobre, ferro e zinco no material seco e as quantidades absorvidas de potássio, cálcio, enxofre, boro, cobre e zinco pela alface na colheita demonstraram não ter efeito diferencial dos tratamentos. $\mathrm{O}$ enxofre e o boro foram os únicos nutrientes que não tiveram suas concentrações e absorção afetadas pelos tratamentos em todas as épocas de amostragem. 


\title{
GROWTH AND NUTRIENT CONTENT BY LETTUCE IN NUTRIENT FILM TECHNIQUE
}

\author{
Author:VANDERLEI NESTOR KOEFENDER \\ Adviser: Prof. Dr. QUIRINO AUGUSTO DE CAMARGO CARMELLO
}

\section{SUMMARY}

Vegetable growth in "NFT" system is very common in the developed world (USA, Australia and some European countries). In Brazil hydroponic crops are found at the "Green Belt" nearly the state capitals and some big cities, where lettuce is mainly grown. Some questions are to be answered, primarily on lettuce growth and nutrient accumulation affected by nutrient solution management.

Lettuce (Lactuca sativa L.) Veronica cultivar was grown in "NFT", where three treatments on the solution management were established after seedling transplanting. They were: every day replacement of the solution volume with water, every day replacement of the solution volume with the initial nutrient solution and every day substitution of the nutrient solution. The effects of the reatments were evaluated in lettuce fresh and dry weight, nutrient concentration and total amounts of nutrient absorbed. Also, $\mathrm{pH}$ variation, electrical conductivity, nutrient concentration and consumed volume were measured in the nutrient solution during 30 days. A complete randomized block design, with ten replications was used. Nutrient solutions were analyzed every day whereas plants 
were analysed at 10,15,20,25 and 30 days and these time sampling constituted the split-splot in the design.

The results showed that the solution management affected the plant ratio of root fresh weight:top fresh weigth and the that the solution consumption was higher when this ratio was low. Plant dry weight and solution $\mathrm{pH}$, electrical conductivity and nutrient concentration changed with the solution management whereas plant fresh weight did not.

Nutrient concentration of sulphur, boron, copper, iron and zinc, and the total amounts of potassium, calcium, sulphur, boron, copper and zinc, in the lettuce plants at harvesting were similar among treatments. Both sulphur and boron concentrations and total amounts in the plants were the only not affected by the treatments in all sampling dates. 


\section{INTRODUÇÃO}

O cultivo de plantas em soluções nutritivas é uma técnica bastante antiga, sendo inicialmente utilizada como técnica de pesquisa e depois passando a ter interesse comercial. Atualmente, é conhecido como cultivo hidropônico ou hidroponia (radicais gregos $=$ trabalho com água) e refere-se a cultivos realizados em solução nutritiva, com ou sem meio de sustentação (substrato) para as plantas.

Sistemas hidropônicos são muito utilizados nos países desenvolvidos. É o caso de Israel (por problemas de deficiências hídricas), do Japão (devido a pouca área disponível), da França, Holanda e Estados Unidos (países com invernos muito rigorosos). Normalmente, a hidroponia é praticada próximo aos grandes centros urbanos (devido a limitação do preço da terra ou a solos poucos férteis), onde o consumidor está perto e a demanda de produtos é elevada.

No Brasil, os cultivos hidropônicos são recentes, mas já podem ser encontrados nos cinturões verdes de Porto Alegre, Belo Horizonte, Rio de Janeiro e São Paulo e também em algumas cidades do interior. As espécies mais cultivadas são a alface e o tomate, seguidos de abobrinha e pepino, pimentão, morango e melão, além de algumas plantas ornamentais. Dessas, a alface é a mais difundida entre os produtores hidropônicos, provavelmente devido ao seu pioneirismo como cultura hidropônica no país, bem como, por se tratar de cultura de manejo mais fácil e principalmente por ser de ciclo curto (45-60 dias) garantindo assim um retorno de capital mais rápido. 
A maior fração dos cultivos hidropônicos de alface, no país, é feita pela técnica do fluxo laminar de solução ("NFT" = Nutrient Film Technique). Os primeiros produtores brasileiros instalaram essa técnica a partir de informações geradas por pesquisas executadas na Europa, Estados Unidos e Austrália, onde as condições de clima, custos de produção e mercado diferem muito das locais. Isso proporcionou, muitas vezes, resultados diferentes dos esperados. Frente a essa situação, alguns produtores desistiram do cultivo, outros criaram e adaptaram suas próprias tecnologias, baseando-se em tentativas e na troca de experiências.

Atualmente, já existem informações científicas a respeito de alface em "NFT", as quais foram desenvolvidas em estações experimentais, centros de pesquisa e universidades brasileiras. No entanto, essas informações ainda não são suficientes e, é necessário que mais pesquisas sejam realizadas para compreender melhor essa técnica, nas condições locais e para essa cultura, para assim, poderem ser resolvidos os problemas que os produtores possam vir a ter, permitindo o avanço dessa área de produção agrícola e do conhecimento científico. A solução nutritiva, desde os primórdios dos cultivos hidropônicos tem sido uma grande dúvida, principalmente no que se refere ao efeito da sua composição e de seu manejo sobre o crescimento e acumulação de nutrientes da alface.

Assim sendo, o presente trabalho teve como objetivos, comparar o efeito de três formas de manejo da solução nutritiva, sobre a produção de material fresco e seco da alface, cultivada pela técnica do fluxo laminar de solução ("NFT"), bem como comparar a concentração de nutrientes do material seco e a absorção desses nutrientes por essa cultura, como conseqüência desses manejos da solução. Além disso, ojetivou-se estudar o comportamento do $\mathrm{pH}$, da condutividade elétrica (CE) e da concentração de nutrientes nas soluções nutritivas manejadas e o consumo de solução nutritiva pela alface após o transplante. 


\section{REVISÃO DE LITERATURA}

\subsection{Técnica do Fluxo Laminar de Solução ("NFT")}

\subsubsection{Conceito}

A técnica do fluxo laminar de solução ("NFT") foi desenvolvida em 1973 pelo inglês Allan Cooper e nesse sistema, as plantas tem suas raízes alojadas em canais instalados em desnível de $1 \%$, através dos quais flui a solução nutritiva (Jones Jr., 1983). Esses canais podem estar próximos ao nível do solo ou em bancadas elevadas (de concreto, madeira, plástico ou metal), e eles precisam ser impermeabilizados internamente com um filme de polietileno ou com algum material inerte para evitar a reação da solução com o material que os constitui. No Brasil, utilizam-se telhas de fibrocimento ou canos de PVC branco, para se fazer o cultivo de alface em "NFT". Esse sistema é fechado, pois a solução nutritiva flui de um reservatório colocado acima do nível das bancadas, sendo distribuída por gravidade para os canais de cultivo, pelos quais flui numa velocidade conhecida, de modo a manter-se uma película de três a dez milímetros de espessura. Depois de percorrer os canais, a solução é coletada em um depósito. Ela é então, bombeada novamente para o reservatório de fornecimento e o ciclo se repete 
(Graves, 1983). Esse ciclo ou seja, a circulação da solução, pode ser contínua ou intermitente (Martinez) ${ }^{1}$

Nas produções comerciais localizadas no Estado de São Paulo, o reservatório de fornecimento é suprimido, bombeando-se a solução diretamente do depósito de coleta para os canais das bancadas. Esse depósito tem capacidade maior que o volume de solução nutritiva em uso, para permitir melhor aeração através de uma queda da solução, no seu retorno.

Durante o cultivo, o volume da solução nutritiva reduz-se, devido às perdas por evaporação e devido à transpiração das plantas. A concentração dos nutrientes na solução também diminui, em função da absorção pelas plantas em desenvolvimento. Esse volume perdido e os nutrientes absorvidos necessitam ser repostos periodicamente à solução. Além disso, a solução precisa ser monitorada e controlada quanto ao seu $\mathrm{pH}$, à condutividade elétrica $(\mathrm{CE})$ e à temperatura (Graves, 1983).

\subsubsection{Vantagens e limitações}

Garcia (1993) afirmou que a "NFT" tem as vantagens de não necessitar aeração suplementar, pois a circulação da solução promove aeração suficiente para a maioria das culturas. Além disso, não necessita de substrato, pois as plantas ficam diretamente nos canais de cultivo.

Jones Jr. (1983) ressaltou para a "NFT" a vantagem da possibilidade da instalação dos canais onde se desenvolvem as raízes com as mais variadas configurações, permitindo uma melhor utilização do espaço e a facilidade de estabelecimento, devido ao custo relativamente baixo dos materiais, pois os

${ }^{1}$ MARTINEZ, H. P. M. Cultivo de flores em hidroponia. Palestra apresentada no $1^{0}$ Encontro de Hidroponia, Campinas, 1995. 
suportes dos canais podem ser em madeira ou em chapas metálicas. Se o material que reveste os canais de polietileno pode ser descartado após cada cultivo, necessitando desinfectar-se apenas a canalização permanente e os reservatórios.

Martinez ${ }^{2}$ afirmou que a "NFT" tem as seguintes vantagens em relação a outros sistemas hidropônicos: o menor custo de implantação; a facilidade de operação; a facilidade e a rapidez de desinfecção entre colheitas e a utilização de produtos pouco tóxicos; o plantio e a colheita simples; a facilidade de uso do espaço; a conservação e a economia de água e nutrientes; a menor contaminação ambiental proveniente dos efluentes das casas-de-vegetação; o grande potencial de automação, pois a formulação, o controle de ajuste, a distribuição e o retorno das soluções nutritivas podem ser feitos automaticamente e; a maior homogenização da solução devido à circulação. A "NFT" permite um maior número de cultivos por ano, em função da facilidade de colheita e de replantio (Graves, 1983).

Como desvantagens, Martinez ${ }^{2}$ citou a possibilidade de acúmulo de etileno nos canais de cultivo; a ocorrência de deficiência de oxigênio em canais muito longos, pelo aquecimento da solução ou pela concentração da solução, pois as plantas absorvem mais água do que nutrientes; a desinfecção entre as colheitas não garante a isenção de patógenos, pois a contaminação pode ocorrer durante o ciclo e a disseminação dos mesmos ocorre facilmente; dificuldade em se fazer reparos ou substituição durante o cultivo, pois o fornecimento da solução não pode ser interrompida.

Jones Jr. (1983) também relatou que o controle das doenças pode ser dificultado em "NFT", pois uma vez que os agentes causadores entraram no

${ }^{2}$ Martinez; op. cit. p. 4. 
sistema, poderão rapidamente ser disseminados de uma planta para a outra. Além disso, comentou sobre a morte de raízes, que ocorre nos períodos de elevada demanda de carboidratos, como por exemplo durante a frutificação e nos períodos de estresse. Quando cessam essas fases, as plantas recuperam o suprimento adequado de carboidratos e novas raízes se desenvolvem. Segundo o autor, a morte de raízes ocorre, provavelmente, em todos os sistemas de cultivo, mas só é claramente visível em "NFT". Outra desvantagem é a necessidade por parte do produtor, de conhecimentos profundos em química (Graves, 1983)

\subsection{Solução Nutritiva em "NFT"}

\subsubsection{Composição e preparo}

A composição da solução nutritiva pode ser baseada na composição química de plantas adultas bem desenvolvidas, que também pode ser usada para se fazer o replanejamento da solução em uso (Steiner, 1980 e Hansen, 1980). Por outro lado, Shippers (1980) ressaltou que não é possível fornecer-se de uma só vez todos os nutrientes, nas quantidades requeridas pela planta, em todo o seu ciclo, uma vez que isso resultaria em concentrações salinas que certamente danificariam as raízes das plantas.

Conforme Furlani (1995), a composição ideal da solução nutritiva não deve depender apenas das concentrações dos nutrientes, mas também de fatores ligados ao cultivo, inclusive devendo a solução ser mudada conforme o sistema hidropônico e os fatores ambientais (luminosidade, temperatura e umidade), época do ano (duração do período diário de luz), a idade das plantas, a espécie e a cultivar em questão. 
Hewitt $^{3}$ citado por Jones Jr. (1982) listou 160 soluções nutritivas que varıam em termos quantitativos, qualitativos e quanto aos sais utilizados no preparo.

Steiner (1980) salientou que se houverem pequenas diferenças na composição das soluções, as plantas tem capacidade de selecionar os íons em proporções favoráveis ao seu desenvolvimento.

Martinez (1988) afirmou que apesar da variação na composição das soluções mais conhecidas, a obtenção de soluções nutritivas ideais para as espécies, variedades e condições particulares permanece ainda como uma icógnita. Segundo a autora, há um consenso entre os pesquisadores de que a solução nutritiva inicial muda facilmente no decorrer do cultivo e que mesmo os produtores usando a condutividade elétrica e o $\mathrm{pH}$ para monitorar soluções, o controle de nutrientes precisa ser melhorado.

Uma vez determinada a composição a ser utilizada, parte-se à etapa de preparo da solução nutritiva. A água a ser utilizada é muito importante. O ideal seria a utilização de água destilada, mas isso não seria possível em cultivos comerciais, devido aos grandes volumes necessários, que inviabilizariam o cultivo economicamente.

Segundo Hansen (1980), a água para ser utilizada em hidroponia deveria ser analisada em relação ao $\mathrm{pH}$, à condutividade elétrica $(\mathrm{CE})$, ao conteúdo de carbonatos, nitrato,fósforo, cálcio, magnésio, enxofre, sódio, cloro, boro, cobre, ferro, manganês, zinco, flúor e bromo. No cálculo da solução, as quantidades de nutrientes presentes na água devem ser descontados das quantidades fornecidas pelos sais, quando somarem mais de $20 \%$ da formulação (Furlani, 1995). O pH

\footnotetext{
${ }^{3}$ HEWITT, E.J. Sand and water culture methods used in the study of plant nutrition. 2. Ed. Bucks: Commonwealth Agricultural Bureaux, 1966 (Comunicado técnico n. 22(Revisado)).
} 
deve ser ajustado ao valor desejado antes da dissolução dos sais na água, para evitar problemas de solubilização dos mesmos e precipitação de nutrientes.

Conforme Benoit (1992), a qualidade da água é um fator decisivo para o sucesso ou o fracasso de cultivos hidropônicos. Os padrões de qualidade da água recomendados, para a utilização em hidroponia são os seguintes: $11,5 \mathrm{mg} \mathrm{L}^{-1}$ de sódio, 35,5 $\mathrm{mg} \mathrm{L}^{-1}$ de cloro, $80,2 \mathrm{mg} \mathrm{L}^{-1}$ de cálcio, 12,2 $\mathrm{mg} \mathrm{L}^{-1}$ de magnésio, 48,1 de sulfato, $244 \mathrm{mg} \mathrm{L}^{-1}$ de carbonato, 0,00270 $\mathrm{mg} \mathrm{L}^{-1}$ de boro, 0,00063 $\mathrm{mg} \mathrm{L}^{-1}$ de cobre, $0,00028 \mathrm{mg} \mathrm{L}^{-1}$ de ferro, 0,00549 $\mathrm{mg} \mathrm{L}^{-1}$ de manganês, 0,00327 $\mathrm{mg} \mathrm{L}^{-1}$ de zinco, $0,00475 \mathrm{mg} \mathrm{L}^{-1}$ de flúor e uma condutividade elétrica de $0,5 \mathrm{mS} \mathrm{cm}^{-1}$. à $25^{\circ}$ C ( Benoit, 1992).

\subsubsection{Uso e manejo}

Dispõe-se de uma série de fórmulas de soluções nutritivas em termos de concentrações, sem se referir a como elas serão utilizadas, qual o volume por planta, qual a freqüência de renovação e de reposição de nutrientes (Jones Jr., 1982). Caso forem utilizadas as fórmulas mais conhecidas como as de Hoagland, Steiner e Cooper, deve-se ter um cuidado especial para não se diminuir o volume de solução por planta e assim causar desbalanços.

De acordo com Castellane \& Araújo (1994), quanto maior for o volume de solução por planta, menores serão as alterações ocorridas nas concentrações de nutrientes. Além disso, um maior volume por planta permite um maior contato dos elementos essenciais com o sistema radicular e uma diluição do efeito de substâncias tóxicas ou inibitórias (Jones Jr., 1983). Para alface, é recomendável utilizar-se volume nunca inferior a um litro por planta (Carmello \& Furlani, 1994; Castellane \& Araújo,1994 e Furlani,1995). 
Segundo Jones Jr. (1983), o monitoramento da solução pode ser relativamente fácil, mas os ajustes necessários $(\mathrm{pH}$, condutividade elétrica e balanço de nutrientes) podem não ser, dependendo do volume da solução nutritiva por planta e da sua freqüência de uso.

Conforme Jones Jr. (1982), as alternativas para se utilizar a solução nutritiva poderiam ser então: aumentar o volume de solução por planta, utilizando-a por curtos períodos (5 a 10 dias), antes da substituição total por uma nova solução; ou monitorar a composição da solução durante seu uso e fazer adições com o objetivo de manter sua composição e pH iniciais.

Jensen \& Collins (1983) sugeriram que se começasse o cultivo com uma solução nova, à qual após uma semana de uso, deveria ser adicionada uma solução com metade da concentração inicial, para repor o volume e os nutrientes gastos. Após a segunda semana de uso descartar-se-ia toda a solução, para então repetir esse procedimento, tantas vezes quantas fossem necessárias, até a colheita da cultura.

Shippers (1980) salientou também, a necessidade da renovação da solução nutritiva ou a reposição periódica dos nutrientes retirados da mesma pela cultura. Wilson (1980) concordou com essa reposição de acordo com a demanda da cultura e considerou-a fundamental para a obtenção de sucesso comercial em cultivos hidropônicos com circulação de solução.

Hansen (1980) registrou que é necessário ter uma distinção entre a solução base (inicial) e a de suplementação (reposição) e que essa solução inicial deve ser definida numa situação estática de alta disponibilidade de nutrientes e a solução de reposição deve ser definida numa situação dinâmica, que considere as demandas de consumo impostas pela cultura durante o ciclo de produção, concordando com aquilo que foi relatado por outros autores. Jones Jr. (1983) 
afirmou que comumente são utilizadas soluções diluídas, normalmente sem os micronutrientes, para repor o volume gasto da solução por evapotranspiração, mantendo-se assim o volume inicial.

Adições de solução nutritiva, de composição igual a inicial, controladas apenas pela concentração total de nutrientes, através da condutividade elétrica, são comuns em "NFT". Porém, se a proporção entre os íons adicionados à solução for muito diferente da razão com que as plantas os absorvem, certos íons acumular-se-ão na solução. Na maioria dos casos, a planta mesmo exerce um controle devido a sua elevada capacidade seletiva. Somente em casos extremos, a solução fica muito desbalanceada, a ponto de causar problemas sérios em sistemas hidropônicos (Steiner, 1980).

As análises químicas são imprescindíveis para se ter uma idéia exata das concentrações de nutrientes em solução (Castellane \& Araújo,1984). O ideal seria fazer análises químicas a cada 2-3 semanas para os macronutrientes e a cada 4-6 semanas para os micronutrientes, mas isso se tornaria muito oneroso para o produtor (Graves, 1983). Porém, Willumsen (1980) esclareceu que o consumo total de nutrientes absorvidos pela planta nunca será igual à redução deles na solução. Heinen et al. (1991) estudaram as relações entre a redução da quantidade de nutrientes em solução e a absorção pelas plantas e observaram que para nitrogênio, fósforo e potássio desapareceram quantidades 1,2-2; 1-1,5 e 1,1-1,7 vezes maiores, respectivamente, da solução do que foram absorvidas pelas plantas. Essa diferença pode ser explicada pela imobilização de nutrientes por microrganismos presentes na solução; pela precipitação de sais; pela desnitrificação e por problemas analíticos. Assim sendo, torna-se necessário levar em consideração os teores de nutrientes na solução nutritiva e nas plantas para 
efetuar o manejo da solução da melhor maneira possível, de modo que os nutrientes estejam disponíveis de acordo com as exigências das plantas.

Conforme Wilson (1980), as adições de solução estoque em práticas comerciais são feitas no tanque reservatório: ou por equipamentos de dosagem automática, onde os nutrientes estão contidos a um pH e CE pré-determinados, ou pela adição manual pelo produtor, uma vez por dia, sendo que no restante do período entra água no sistema para repor o líquido perdido.

\subsubsection{Condutividade Elétrica}

A condutividade elétrica (CE) fornece informações sobre a concentração de sais na solução nutritiva, mas não permite que se conheçam as concentrações individuais dos nutrientes, além do que, os micronutrientes pouco ou nada afetam a mesma (Graves, 1983; Jensen \& Collins, 1983 e Resh, 1987).

Segundo Steiner (1980), a adição de sais baseada na condutividade elétrica pode ser feita, mas deve-se utilizar proporções o mais próximas possíveis das razões em que os nutrientes são consumidos pelas plantas.

A CE pode ajudar a se decidir pela complementação da solução ou pela sua total renovação. De um modo geral, recomenda-se manter o valor entre 2,0 e 3,0 $\mathrm{mS} \mathrm{cm}^{-1}$, para a "NFT"(Carmello \& Furlani, 1994 e Castellane \& Araújo, 1994).

\subsubsection{2. $\mathrm{pH}$}

Conforme Castellane \& Araújo (1994) as plantas toleram uma maior amplitude de variação no pH nas soluções nutritivas que no solo. Jones Jr.(1983) afirmou que, em hidroponia, o pH da solução é menos crítico nas soluções recirculantes do que nas estáticas, desde que não saia da faixa de 5,0 a 7,0. Graves 
(1983) indicou como ideais valores entre 5,5 e 6,5 para os cultivos comerciais, mas relatou que os sistemas de controle automático são regulados para corrigir o $\mathrm{pH}$ a 6,0 e que seus eletrodos comandam esse ajuste somente em valores menores que 5,0 e maiores que 7,0 .

$\mathrm{O} \mathrm{pH}$ afeta a disponibilidade de certos elementos, principalmente os micronutrientes, estimulando absorção excessiva em valores de $\mathrm{pH}$ baixos e precipitação em valores de $\mathrm{pH}$ elevados (Jones Jr., 1983). Além disso, em pH abaixo de 5,0, a absorção de cátions é mais afetada do que a de ânions, ocorrendo o contrário em valores de $\mathrm{pH}$ acima de 7,0 (Graves, 1983). Nesses valores elevados ocorre a competicão entre os ânions $\mathrm{OH}^{-}$e os ânions essenciais $\left(\mathrm{NO}_{3}\right.$, $\mathrm{SO}_{4}^{-}, \mathrm{Cl}^{2-}$ e $\mathrm{MoO}_{4}{ }^{2-}$ ) e em valores baixos ocorre competição entre os cátions $\mathrm{H}^{+} \mathrm{e}$ os cátions essenciais $\left(\mathrm{NH}_{4}^{+}, \mathrm{K}^{+}, \mathrm{Ca}^{2+}, \mathrm{Mg}^{2+}, \mathrm{Cu}^{2+}, \mathrm{Fe}^{2+}, \mathrm{Mn}^{2+}, \mathrm{Zn}^{2+}\right)$, além de que conforme Carmello \& Furlani (1994), em valores de $\mathrm{pH}$ mais baixos que 3,5 ocorre um efeito tóxico direto dos íons $\mathrm{H}^{+}$sobre as células vegetais). Portanto, o controle do $\mathrm{pH}$ é importante para manter os elementos essenciais em solução e evitar a toxicidade por absorção excessiva. Variações no $\mathrm{pH}$ ocorrem durante o dia, devidas às diferenças na solubilidade do $\mathrm{CO}_{2}$ na solução nutritiva, mas que não chegam a ser significativas de modo a exigir algum controle (Jones Jr., 1983).

Segundo Willumsen (1980), as plantas afetam o pH continuamente, durante o período de cultivo. As raízes expelem $\mathrm{H}^{+}$quando os cátions são absorvidos mais rapidamente que os ânions e expelem $\mathrm{HCO}_{3}{ }^{-}$e $\mathrm{OH}^{-}$quando ocorre maior absorção de ânions (na prática, o pH normalmente aumenta com o tempo). Coic \& Lesaint ${ }^{4}$, citados por Willumsen (1980), afirmaram que essa

\footnotetext{
${ }^{4}$ COIC, Y. \& LESAINT, C. The equilibrium between potassium and others cations in the organs of higher plants. Proceedings of the International Potash In stitute. v. 8, p. 93-103,1971.
} 
diferença nos íons expelidos depende da espécie vegetal em questão e do balanço entre cátions e ânions na solução.

Wilcox (1982) afirmou que o $\mathrm{pH}$ aumenta sempre que o nitrogênio for fornecido para as plantas em soluções nutritivas apenas na forma de $\mathrm{NO}_{3}{ }^{-}$. Segundo Clark (1982), quando o nitrogênio é fornecido às plantas em soluções nutritivas somente na forma de $\mathrm{NO}_{3}{ }^{\circ}$, o $\mathrm{pH}$ vai aumentando com o passar do tempo, até atingir valores em torno de 7,0 e estabilizar-se. Caso o nitrogênio seja fornecido somente na forma de $\mathrm{N}_{-} \mathrm{NH}_{4}{ }^{+}, \mathrm{o} \mathrm{pH}$ vai diminuindo com o passar do tempo até chegar a valores em torno de 4,0 e também estabilizar-se. Se porém, se fornecer o nitrogênio em ambas as formas $\left(\mathrm{NH}_{4}{ }^{+} \mathrm{e} \mathrm{NO}_{3}{ }^{-}\right)$até o limite de proporções de 1:9, respectivamente, os valores do $\mathrm{pH}$ baixam inicialmente até todo $\mathrm{o}_{\mathrm{NH}_{4}}^{+}$ser absorvido pelas plantas, passando a aumentar depois. Se o nitrogênio for fornecido em proporções maiores que 1 parte de $\mathrm{NH}_{4}{ }^{+}: 9$ partes de $\mathrm{NO}_{3}{ }^{-}$, os valores de $\mathrm{pH}$ seguem o mesmo comportamento observado quando somente $\mathrm{N}^{-\mathrm{NH}_{4}}{ }^{+}$é fornecido. Comportamentos semelhantes foram observados por Jones Jr. (1983). Assim sendo, um certo controle do $\mathrm{pH}$ pode ser obtido, escolhendo-se uma determinada proporção entre os íons nitrato $\left(\mathrm{NO}_{3}{ }^{-}\right)$e amônio $\left(\mathrm{NH}_{4}{ }^{+}\right)$, quando se calcula a quantidade de nitrogênio a ser utilizada.

Graves (1983) recomendou que se façam leituras e correções diárias para o caso de controle manual do pH. Jones Jr. (1983) recomendou que se monitore continuamente e se adicione ácido ou base conforme a necessidade de ajuste no pH da solução. Por outro lado, segundo esse autor, existem plantas que acidificam a região próxima as suas raízes, para aumentar sua habilidade de absorver nutrientes, tal como o ferro. Nesse caso se a solução for constantemente ajustada em seu pH para próximo à neutralidade, pode ser que se esteja interferindo na habilidade natural dessas plantas em aumentar sua absorção iônica. Sugeriu então 
esse autor, que o pH não deveria ser ajustado, permitindo-se assim, que o valor de $\mathrm{pH}$ adequado seja atingido pelos próprios mecanismos da planta.

Para os casos em que ajuste de $\mathrm{pH}$ é necessário, o $\mathrm{NaOH}$ é a base preferida, enquanto que o $\mathrm{HCl}$ é o ácido preferido, por não conterem elementos essenciais (Jones Jr., 1983). A absorção desigual de íons pelas plantas, juntamente com a constante adição de água para repor o volume perdido por transpiração, geralmente aumenta o pH da solução. Se a água for "dura", quantidades razoáveis de ácido são necessárias para se reduzir o pH dessa água e se neutralizar o bicarbonato produzido pelas plantas. Se esse ácido contiver elementos essenciais como é o caso de $\mathrm{HNO}_{3}, \mathrm{H}_{2} \mathrm{SO}_{4}$ e $\mathrm{H}_{3} \mathrm{PO}_{4}$, poderá haver acúmulo de nitrato, sulfato ou fosfato, respectivamente. Esses íons contribuirão também com a salinidade e se o sistema for controlado a uma CE constante, ter-se-á uma falsa idéia da situação da solução em relação à concentração dos elementos essenciais, como um todo. Nesse caso, será necessário ou aumentar-se a condutividade com o tempo, ou trocar-se a solução por uma nova ou ainda aumentar-se o volume de solução por planta (Graves, 1983).

\subsection{Alface em "NFT"}

\subsubsection{Absorção de nutrientes e produção}

A alface não tem somente uma elevada capacidade de selecionar íons para adequar às suas necessidades, mas também, sempre que as proporções dos nutrientes na solução mudarem, causando assim, desvios na absorção, ocorre pouca alteração na sua produção (Steiner, 1980).

Shippers (1980) estudou os efeitos de cultivos sucessivos de alface em "NFT", com a mesma solução nutritiva $\left(1,15 \mathrm{~L}\right.$ planta $\left.^{-1}\right)$, no que se referia à 
redução dos macronutrientes nitrogênio, fósforo e potássio na solução, no decorrer desses cultivos. Ele observou que a redução dos nutrientes na solução foi mínima, no primeiro e segundo cultivos e atribuiu isso ao lento crescimento e ao pequeno desenvolvimento da alface, nos períodos de baixa luminosidade (inverno). Isso fez com que a solução inicial suprisse as exigências nutricionais durante o primeiro ciclo e segundo esse autor, provavelmente, supriria também as do segundo, se as quantidades de nutrientes tivessem sido elevadas ao nível inicial, no início do segundo ciclo. No terceiro e quarto cultivos, o crescimento da alface foi maior, principalmente no final do ciclo (condições de maior luminosidade) e conseqüentemente, a diminuição da concentração dos nutrientes na solução foi mais rápida, exigindo suplementação, antes do final do ciclo. Assim sendo, a redução dos nutrientes na solução, no decorrer dos cultivos, é função da velocidade de crescimento da planta, que por sua vez depende das condições ambientais.

A extração de nutrientes pela alface varia conforme a época do ano, ficando entre 8 e $16 \mathrm{mg}$ de nitrogênio; 2,5 e $5 \mathrm{mg}$ de fósforo e 11,5 e $13 \mathrm{mg}$ de potássio por planta por dia e durante o ciclo completo de $0,45 \mathrm{~g}$ de nitrogênio; $0,15 \mathrm{~g}$ de fósforo e $0,65 \mathrm{~g}$ de potássio (Shippers, 1980).

A cultivar "Grand Rapids" cultivada em "NFT" produziu 22,24 g planta $^{-1}$ de material seco (MS) e extraiu $930 \mathrm{mg}$ planta $^{-1}$ de nitrogênio, $120 \mathrm{mg}_{\text {planta }}{ }^{-1} \mathrm{de}$ fósforo, $1400 \mathrm{mg}_{\text {planta }}{ }^{-1}$ de potássio, $310 \mathrm{mg}$ planta $^{-1}$ de cálcio, $60 \mathrm{mg}_{\text {planta }}{ }^{-1} \mathrm{de}$ magnésio, 0,57 mg planta ${ }^{-1}$ de boro, 0,25 mg planta ${ }^{-1}$ de cobre, 9,03 mg planta ${ }^{-1} \mathrm{de}$ ferro, 1,47 mg planta ${ }^{-1}$ de manganês e $2,2 \mathrm{mg} \mathrm{planta}^{-1}$ de zinco, durante o ciclo todo (Furlani, 1995).

Plantas de alface da cultivar Verônica produzida em "NFT" em ponto de colheita apresentaram uma produção de $16,78 \mathrm{~g} \mathrm{planta}^{-1} \mathrm{de} \mathrm{MS}$ e extraíram 660 
mg planta ${ }^{-1}$ de nitrogênio, $140 \mathrm{mg}_{\text {planta }}{ }^{-1}$ de fósforo, $590 \mathrm{mg}$ planta $^{-1}$ de potássio, $230 \mathrm{mg}$ de cálcio, $60 \mathrm{mg}$ planta $^{-1}$ de magnésio, $1,15 \mathrm{mg} \mathrm{planta}^{-1}$ de boro, 0,23 mg planta $^{-1}$ de cobre, 11,6 mg planta ${ }^{-1}$ de ferro, $1,47 \mathrm{mg}_{\text {planta }}{ }^{-1}$ de manganês e 2,87 mg planta $^{-1}$ de zinco (ESALQ/USP) ${ }^{5}$. Segundo Faquin et al. (1996) essa mesma cultivar de alface produziu 385,5 g de MF e 18,24 g de MS (2 plantas compondo o maço comercializado) aos 30 dias pós-transplante e extraiu 398,05 mg planta ${ }^{-1}$ de nitrogênio, 70,8 mg planta ${ }^{-1}$ de fósforo, $475,45 \mathrm{mg}_{\text {planta }}{ }^{-1}$ de potássio, 162,25 $\mathrm{mg}$ planta $^{-1}$ de cálcio, 47,85 mg planta ${ }^{-1}$ de magnésio, 30,2 $\mathrm{mg}_{\text {planta }}{ }^{-1}$ de enxofre, 0,22 mg planta ${ }^{-1}$ de boro, 0,39 mg planta ${ }^{-1}$ de cobre, 2,45 mg planta ${ }^{-1}$ de ferro, 1,01 mg planta ${ }^{-1}$ de manganês e $0,53 \mathrm{mg} \mathrm{planta}^{-1}$ de zinco. Além disso, no MS apresentou 43,64 $\mathrm{g} \mathrm{kg}^{-1}$ de nitrogênio, 7,76 $\mathrm{g} \mathrm{kg}^{-1}$ de fósforo, 52,13 $\mathrm{g} \mathrm{kg}^{-1} \mathrm{de}$ potássio, 17,79 $\mathrm{g} \mathrm{kg}^{-1}$ de cálcio, 5,24 $\mathrm{g} \mathrm{kg}^{-1}$ de magnésio, 3,31 $\mathrm{g} \mathrm{kg}^{-1}$ de enxofre, $24,13 \mathrm{mg} \mathrm{kg}^{-1}$ de boro, $42,77 \mathrm{mg} \mathrm{kg}^{-1}$ de cobre, $269,18 \mathrm{mg} \mathrm{kg}^{-1}$ de ferro, 111,13 de manganês $\mathrm{mg} \mathrm{kg}^{-1}$ e $58,55 \mathrm{mg} \mathrm{kg}^{-1}$ de zinco.

\subsection{2. $\mathrm{CE} \mathrm{e} \mathrm{pH}$}

Para alface especificamente a recomendação de condutividade elétrica é de até $2,5 \mathrm{mS} \mathrm{cm}^{-1}$ (Castellane \& Araújo, 1994). Esse valor está entre os limites (2,5-3,0 $\left.\mathrm{mS} \mathrm{cm}^{-1}\right)$ recomendados de CE para alface por Benoit \& Ceustermans (1989). Porém Huett (1994) afirmou que as condutividades de $2,0-2,5 \mathrm{mS} \mathrm{cm}^{-1}$, normalmente recomendadas para alface em "NFT", são responsáveis pela redução da produção, bem como pelo aparecimentro de queima dos bordos ("tipburn").

Huett (1994) estudou o comportamento de várias cultivares de alface, utilizando soluções nutritivas com $\mathrm{CE}$ de 0,$4 ; 1,0 ; 1,6 ; 2,4$ e $3,6 \mathrm{mS} \mathrm{cm}^{-1}$ e na mais

\footnotetext{
Resultados obtidos em análise de rotina do laboratório de análises de plantas do Setor de Nutrição Mineral de Plantas do Departamento de Química da Escola Superior de Agricultura "Luiz de Queiroz" da Universidade de São Paulo, 1996.
} 
baixa condutividade encontrou deficiências de nitrogênio e potássio e teores de cálcio e magnésio elevados, no cultivar "Coolguard". A partir da CE de 1,0 mS $\mathrm{cm}^{-1}$, desapareceram essas deficiências. e os terores de cálcio e magnésio aumentaram, em relação aos da CE mais baixa, porém voltaram a cair nos valores mais elevados de CE. A maior produção de material fresco (MF) de cabeças foi obtida com a CE de 1,6 $\mathrm{mS} \mathrm{cm}^{-1}$, seguida da CE de $1,0 \mathrm{mS} \mathrm{cm}^{-1}$ e essas diferiram significativamente das demais, em todos os cultivares. A recomendação foi de se utilizar a $\mathrm{CE}$ de $1,0 \mathrm{mS} \mathrm{cm}^{-1}$, para diminuir os riscos de ocorrência de queima dos bordos. Visualmente o desenvolvimento das cabeças da alface pareceu ser satisfatório nas condutividades estudadas, sem apresentar sintomas de deficiências ou toxidez, e todas apresentaram tamanho suficiente para a comercialização.

Burrage \& Varley (1980) encontraram grande uniformidade em plantas de alface, variando a $\mathrm{CE}$ de 1,$5 ; 2,4 ; 2,9$ e $3,5 \mathrm{mS} \mathrm{cm}^{-1}$. No entanto, a percentagem de plantas afetadas por queima dos bordos diminuiu com o aumento da condutividade, contrariando a afirmação de Huett (1994). Em relação ao Ca, o comportamento encontrado foi semelhante, diminuindo com o aumento da $\mathrm{CE}$. Além disso, avaliaram a percentagem de material seco e obtiveram um aumento significativo, de acordo com o aumento da CE.

Boon et al. (1988), cultivando alface na primavera e no verão, não observaram diferença significativa para MF de cabeças de alface, com o aumento da $\mathrm{CE}$ de 1,2 até $3,0 \mathrm{mS} \mathrm{cm}{ }^{-1}$, quando não havia $\mathrm{N}-\mathrm{NH}_{4}{ }^{+}$na solução. Na presença de $20 \%$ de $\mathrm{N}_{-} \mathrm{NH}_{4}$ a MF de cabeças na primavera, reduziu com o aumento da $\mathrm{CE}$, enquanto no verão esse efeito não foi claro. Isso prova a necessidade de realizarse análises químicas da solução nutritiva além de monitorá-la através da $\mathrm{CE}$ para possibilitar seu melhor manejo. 
Benoit \& Ceustermans (1989) afirmaram que não é fácil estabelecer-se uma relação segura entre a concentração de nutrientes (estimada pela $\mathrm{CE}$ ) da solução nutritiva e a produção de plantas macias. Se a CE for alta, consegue-se obter plantas bem desenvolvidas mas quebradiças, se a $\mathrm{CE}$ for baixa as plantas desenvolvem-se bem, ficando macias, mas aparece queima dos bordos.

É importante lembrar, que a CE fornece informações sobre as concentrações individuais dos nutrientes em solução. É compreensível portanto, que resultados diferentes quanto à produção possam ser observados em valores iguais de $\mathrm{CE}$. Isso porque, proporções variadas entre os nutrientes podem levar a se obter uma mesma CE. Além disso, elementos não essenciais podem acumularse na solução, contribuindo para o aumento da CE.

Quanto ao pH, Furlani (1995) recomendou a manutenção do pH entre 5,0 e 7,0, mas indicou como sendo mais adequada a faixa de 6,0 a 6,5 para alface, em "NFT", o que concorda com Jones Jr. (1983).

Bres \& Weston (1994) encontraram aumentos significativos na absorção de fósforo, potássio, cálcio e magnésio, em duas cutlivares de alface ("Summer Bibb" e "Buttercrunch"), 25 dias pós-transplante, quando aumentaram o $\mathrm{pH}$ da solução $(5,0 ; 5,5 ; 6,0$ e 6,5. Esses autores observaram também aumentos na produção de MF que não foram significativos.

A disponibilidade dos nutrientes para as plantas em soluções nutritivas é função do $\mathrm{pH}$ e das quantidades e formas nas quais forem fornecidos. Assim sendo, pode-se esperar resultados variados em termos de absorção de nutrientes e produção de MF, quando varia-se esses fatores. Além disso, as condições meteorológicas afetam muito os processos de absorção, no que se refere à proporção e às quantidades de nutrientes absorvidas, tanto para alface, como em todas as plantas cultivadas em soluções nutritivas (Steiner, 1980). 


\section{MATERIAL E MÉTODOS:}

\subsection{Condições experimentais:}

O experimento foi conduzido no Departamento de Química da Escola Superior de Agricultura Luiz de Queiroz (ESALQ), em estrutura própria para "NFT", entre os dias 23 de maio a 22 de junho de 1996. As condições meteorológicas nesse período, tomadas na Estação Meteorológica do Departamento de Física e Meteorologia da ESALQ/USP e constam no Anexo A.

A estrutura para o "NFT" constou de uma cobertura plástica sob a qual foram montadas as bancadas. Foram montadas 4 bancadas as quais foram feitas com cavaletes de $0,8 \mathrm{~m}$ de altura, sobre os quais repousaram telhas de cimentoamianto com canais de $3,5 \mathrm{~cm}$ de profundidade e $9 \mathrm{~cm}$ de largura, recobertas por um filme de polietileno preto, em cujos canais fluiu a solução nutritiva e nos quais ficaram alojadas as raízes das plantas. Utilizou-se 4 telhas de $0,5 \mathrm{~m}$ de largura por 2,4 m de comprimento para montar cada bancada, obtendo-se assim bancadas com $2 \mathrm{~m}$ de largura por 2,4 de comprimento. Cada canal foi considerado como uma parcela experimental, alojando 5 plantas. Cada bancada tinha 20 canais, alojando assim cinco blocos, sendo que cada bloco constou de três canais, portanto um canal por tratamento. Entre os blocos foram utilizados canais de bordadura. 
O espaçamento entre as plantas nos canais foi de $40 \mathrm{~cm}$ e entre plantas de canais distintos de $18 \mathrm{~cm}$, numa disposição com formato de losango, conforme o esquema da figura 1.

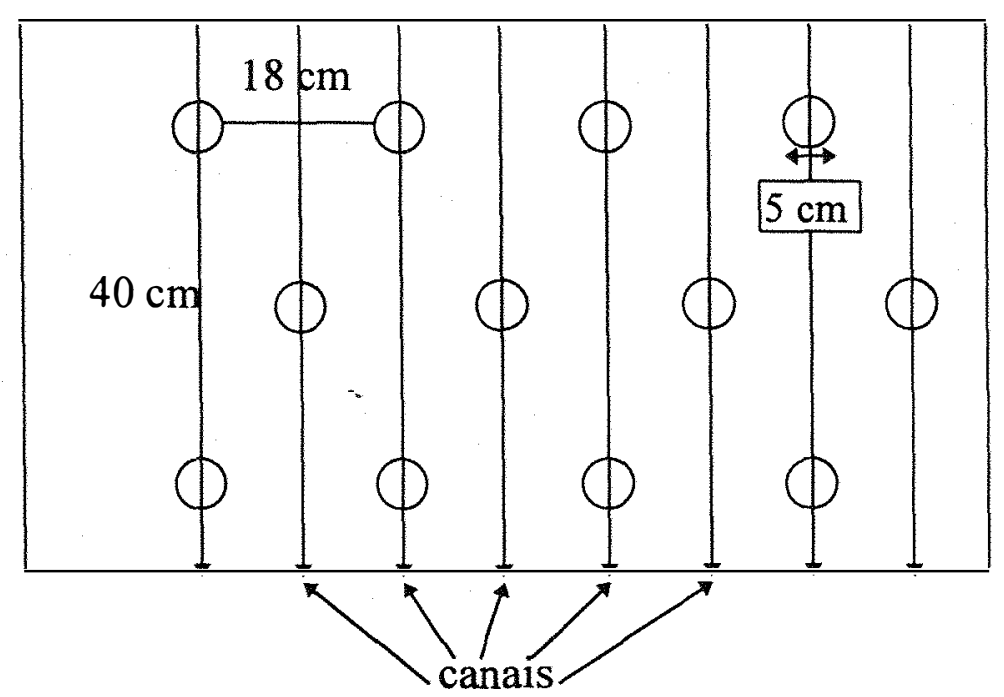

Figura 1. Aspecto da disposição dos canais e do espaçamento dos furos que alojaram as plantas de alface.

A declividade das telhas foi de $2 \%$ e a vazão da solução no canal foi de $300 \mathrm{~mL} \mathrm{~min}^{-1}$. Sobre as telhas recobertas, instalaram-se placas de isopor com 1 $\mathrm{cm}$ de espessura, com furos de $5 \mathrm{~cm}$ de diâmetro (Figura 1) onde ficaram alojadas e sustentadas as plantas. Instalou-se quatro bancadas, duas com as parcelas úteis e mais duas com plantas para a reposição, uma vez que as plantas coletadas precisavam ser substituídas por outras no mesmo estádio de desenvolvimento, para evitar-se diferenças no que se refere à competição por luz e absorção de nutrientes.

\subsection{Delineamento experimental, tratamentos e condução do experimento:}

O delineamento experimental em blocos ao acaso foi utlizado com dez repetições. As coletas de plantas aos 10, 15, 20, 25 e $30 \mathrm{dpt}$ inferiram um 
esquema de parcelas subdividas no tempo no delineamento experimental. Os tratamentos foram os seguintes:

a) reposição diária do volume de solução nutritiva (RVA) evapotranspirado, com água e substituição da mesma por uma solução nova, quando a $\mathrm{CE}$ chegou a $1 \mathrm{mS} \mathrm{cm} \mathrm{cm}^{-1}$;

b) reposição diária do volume de solução (RVS) evapotranspirado com solução de composição igual à inicial e substituição da mesma por uma nova, quando a CE chegou, a $4,0 \mathrm{mS} \mathrm{cm}^{-1}$;

c) renovação diária total (RDT) da solução com outra de composição igual à inicial, simulando-se a reposição do volume e dos nutrientes gastos.

Nos tratamentos RVA e RVS a CE chegou a 1 e $4 \mathrm{mS} \mathrm{cm}^{-1}$, aos 23 dias, quando se substituiram essas soluções por novas.

Tabela 1 - Quantidade de sais utilizados para preparar $1 \mathrm{~L}$ de solução nutritiva

\begin{tabular}{cc}
\hline FONTES DE MACRONUTRIENTES & $\mathrm{g}$ \\
\hline $\mathrm{Ca}\left(\mathrm{NO}_{3}\right)_{2} \cdot 4 \mathrm{H}_{2} \mathrm{O}$ & 1,20 \\
$\mathrm{KNO}_{3}$ & 0,26 \\
$\left(\mathrm{NH}_{4}\right)_{2} \mathrm{PO}_{4}$ & 0,15 \\
$\mathrm{KCl}$ & 0,25 \\
$\mathrm{MgSO}_{4} \cdot 7 \cdot \mathrm{H}_{2} \mathrm{O}$ & 0,50 \\
\hline FONTES DE MICRONUTRIENTES & $\mathrm{mg}$ \\
\hline $\mathrm{H}_{3} \mathrm{BO}_{3}$ & 2,86 \\
$\mathrm{CuCl}_{2}$ & 0,08 \\
$\mathrm{MnCl}_{2} 4 \mathrm{H}_{2} \mathrm{O}$ & 1,81 \\
$\mathrm{H}_{2} \mathrm{MoO}_{4} \cdot \mathrm{H}_{2} \mathrm{O}$ & 0,02 \\
$\mathrm{ZnCl}_{2}$ & 0,22 \\
\hline
\end{tabular}

Fonte: Departamento de Química - ESALQ/USP.

A solução nutritiva foi preparada utilizando-se água de torneira, a qual tinha valor de $\mathrm{pH}$ de 7,0 e CE de $0,15 \mathrm{mS} \mathrm{cm}^{-1}$. As concentrações de nutrientes na 
água foram de 25,7 $\mathrm{mg} \mathrm{L}^{-1}$ de $\mathrm{N}, 1,5 \mathrm{mg} \mathrm{L}^{-1}$ de $\mathrm{P}, 6,2 \mathrm{mg} \mathrm{L}^{-1}$ de $\mathrm{K}, 7,9 \mathrm{mg} \mathrm{L}^{-1} \mathrm{de}$ Ca, 2,0 mg L ${ }^{-1}$ de $\mathrm{Mg}, 18,4 \mathrm{mg} \mathrm{L}^{-1}$ de S, 0,19 $\mathrm{mg} \mathrm{L}^{-1}$ de B, 0,004 $\mathrm{mg} \mathrm{L}^{-1}$ de $\mathrm{Cu}$, $0,77 \mathrm{mg} \mathrm{L}^{-1}$ de Fe, $0,001 \mathrm{mg} \mathrm{L}^{-1}$ de $\mathrm{Mn}$ e $0,1 \mathrm{mg} \mathrm{L}^{-1}$ de $\mathrm{Zn}$.

As concentrações de nutrientes minerais por litro de solução nutritiva foram de 196,7 $\mathrm{mg} \mathrm{L}^{-1}$ de N, 40,4 $\mathrm{mg} \mathrm{L}^{-1}$ de P, 231,3 $\mathrm{mg} \mathrm{L}^{-1}$ de $\mathrm{K}, 203,4 \mathrm{mg} \mathrm{L}^{-1}$ de Ca, 48,8 mg L ${ }^{-1}$ de $\mathrm{Mg}, 65 \mathrm{mg} \mathrm{L}^{-1}$ de S, 0,5 $\mathrm{mg} \mathrm{L}^{-1}$ de B, 0,038 $\mathrm{mg} \mathrm{L}^{-1}$ de Cu, 5 $\mathrm{mg} \mathrm{L}^{-1}$ de Fe, 0,01 $\mathrm{mg} \mathrm{L}^{-1}$ de Mo, 0,5 $\mathrm{mg} \mathrm{L}^{-1}$ de $\mathrm{Mne} 0,10 \mathrm{mg} \mathrm{L}^{-1}$ de $\mathrm{Zn}$. As quantidades de adubos e/ou sais para compor a solução nutritiva com essas quantidades de nutrientes constam na tabela 1.

Para o fornecimento do ferro utilizou-se uma solução estoque de $\mathrm{Fe}$ EDTA que foi preparada dissolvendo-se 35,2 g de EDTA-dissódico em $89 \mathrm{ml}$ de $\mathrm{NaOH}(1 \mathrm{~N})$; misturando-se com $24,9 \mathrm{~g}$ de $\mathrm{Fe}_{2} \mathrm{SO}_{4}$. $7 \mathrm{H}_{2} \mathrm{O}$; adicionando-se água desmineralizada para completar $1 \mathrm{~L}$ e borbulhando-se por uma noite (Sarruge, 1975). Cada ml dessa solução continha $5 \mathrm{mg}$ de Fe.

Utilizou-se o volume de 1 litro de solução nutritiva por planta perfazendo um total de 135 litros de solução nutritiva por tratamento. Circulou-se a solução a intervalos de 15 minutos por períodos de 15 minutos, durante o dia e a intervalos de 3 horas por períodos de 15 minutos, durante a noite. Esse controle do dia e noite fez-se com um temporizador ("timer") especial da marca HIDROTEC que identificou ambos os períodos através de um sensor fotoelétrico.

$\mathrm{O} \mathrm{pH}$ das soluções manejadas foi ajustado diariamente em torno de 6,0 , utilizando-se soluções $1 \mathrm{~N}$ de $\mathrm{NaOH}$ ou $\mathrm{HCl}$, de acordo com a necessidade.

A planta utilizada foi a alface ( Lactuca sativa L.) da cultivar Verônica, que é do tipo repolhuda crespa e é recomendada para as condições de verão, podendo ser cultivada o ano inteiro. 
A semeadura foi feita em bandejas de isopor com 288 células, em algodão. As bandejas permaneceram flutuando na solução nutritiva que foi recirculada constantemente durante o dia, para promover a oxigenação. A solução na qual foram produzidas as mudas tinha $249,5 \mathrm{mg} \mathrm{L}^{-1}$ de nitrogênio, $32 \mathrm{mg} \mathrm{L}^{-1}$ de fósforo, $294 \mathrm{mg} \mathrm{L}^{-1}$ de potássio, $190 \mathrm{mg} \mathrm{L}^{-1}$ de cálcio, $24 \mathrm{mg} \mathrm{L}^{-1}$ de magnésio, $33 \mathrm{mg} \mathrm{L}^{-1}$ de enxofre, 0,18 $\mathrm{mg} \mathrm{L}^{-1}$ de boro, 0,025 $\mathrm{mg} \mathrm{L}^{-1}$ de cobre, 2,5 $\mathrm{mg} \mathrm{L}^{-1}$ de ferro, $0,325 \mathrm{mg} \mathrm{L}^{-1}$ de manganês, $0,05 \mathrm{mg} \mathrm{L}^{-1}$ de molibdênio e $0,10 \mathrm{mg} \mathrm{L}^{-1} \mathrm{de}$ zinco.

$\mathrm{O}$ ajuste do $\mathrm{pH}$ e as adições de água foram feitas diariamente repondo o volume da solução nutritiva e uma vez por semana a solução foi corrigida para os valores iniciais de nutrientes.

$\mathrm{O}$ transplante para as bancadas ocorreu 25 dias pós-semeadura (quando as plantas tinham de 4 a 5 folhas bem desenvolvidas). As produções de material fresco (MF) e material seco (MS), concentrações de nutrientes no MS e quantidades absorvidas de nutrientes por essas mudas, constam nas tabelas 2 e 3 .

Tabela 2. Produção de material fresco e seco (das raízes, parte aérea e planta inteira) das mudas de alface por ocasião do transplante cv. Verônica, em "NFT" (média de 10 plantas).

\begin{tabular}{lccc}
\hline & RAIZES & PARTE AÉREA & PLANTA INTEIRA \\
\hline MF & $0,37(\sigma=0,16)$ & $3,15(\sigma=1,01)$ & $3,52(\sigma=1,17)$ \\
MS & $0,01(\sigma=0,006)$ & $0,14(\sigma=0,06)$ & $0,15(\sigma=0,06)$ \\
\hline
\end{tabular}


Tabela 3. Concentrações no MS e absorção de nutrientes pelas mudas de alface cv. Verônica, em "NFT", por ocasião do transplante (subamostra retirada de amostra de 100 plantas).

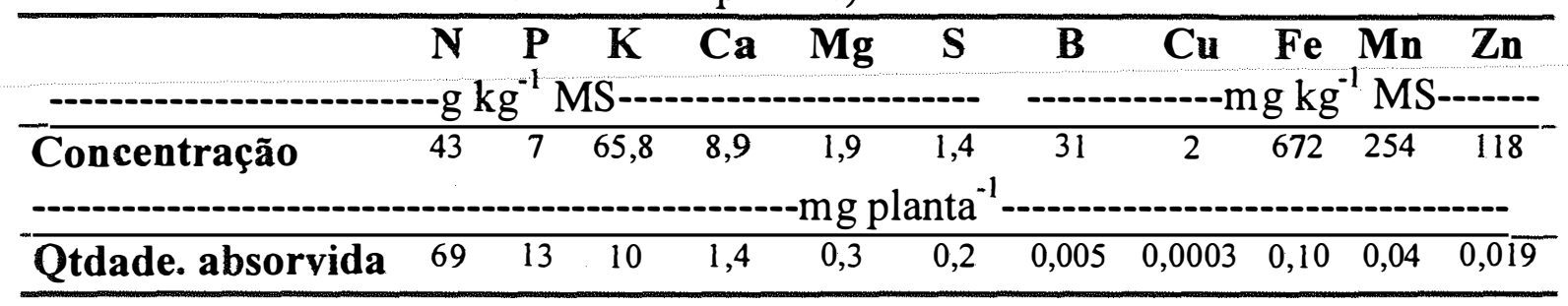

\subsection{Amostragens e determinações}

Coletas diárias de amostras (com $100 \mathrm{~mL}$ cada) de solução nutritiva foram realizadas nos tratamentos. Nessas amostras mediu-se o $\mathrm{pH}$ e a CE com aparelhos digitais e efetuaram-se as determinações de macro e micronutrientes, conforme metodologia analítica descrita por Sarruge e Haag (1974).

Coletaram-se plantas, por ocasião do transplante e a partir dessa data aos $10,15,20,25$ e 30 dias (colheita). As quantidades de plantas coletadas por amostra em cada época, foram de 100 plantas no transplante, 2 plantas no $10^{\circ}$ dia pós-transplante, 2 plantas no $15^{\circ}$ dia pós-transplante e 1 planta no $20^{\circ}, 25^{\circ}$ e $30^{\circ}$ dia pós-transplante.

As plantas foram coletadas e separadas em parte aérea e sistema radicular. As raízes foram lavadas com $\mathrm{HCl} 0,1 \mathrm{~N}$ e água destilada para remover os nutrientes aderidos externamente a elas. Ambas as partes foram pesadas para se avaliar a produção de material fresco (MF), acondicionadas em sacos de papel e em seguida, mantidas em estufa à $65^{\circ} \mathrm{C}$, até atingirem peso constante. Efetuou-se então nova pesagem, para avaliar-se a quantidade de material seco (MS) e procedeu-se a moagem conjunta de ambas as partes da planta, devido a insuficiência de massa de material seco do sistema radicular para se efetuar as determinações das concentrações de nutrientes. 
Analisou-se a planta inteira para as concentrações de macro e micronutrientes, conforme a metodologia descrita por Sarruge \& Haag (1974).

\subsection{Análises estatísticas}

Os resultados de MF, MS, concentração de nutrientes no MS e absorção de nutrientes foram submetidos à análise de variância com o uso do teste $F$ $(\alpha=0,05)$.

Quando esse teste foi significativo para a interação entre épocas e tratamentos, prosseguiu-se a análise com o teste de comparações de médias de Tukey $(\alpha=0,05)$, para os tratamentos nas épocas e a análise de regressão polinomial dos tratamentos entre as épocas de coleta. Para as regressões polinomiais aplicou-se o teste $\mathrm{F}(\alpha=0,05)$ à análise de variância, até o terceiro grau. Adotaram-se as equações de regressão de cada tratamento de maior grau que foi significativo, a esse nível de probabilidade, mesmo que algumas com grau menor tenham sido não significativas. Quando a interação entre épocas e tratamentos não foi significativa, mas o efeito de tratamentos sim, considerou-se os resultados obtidos pelo teste de Tukey para médias gerais dos tratamentos em todas as épocas. No caso, para regressão apresentou-se apenas uma única curva para representar o comportamento médio dos tratamentos. Todas as análises estatísticas foram feitas no programa estatístico SANEST. 


\section{RESULTADOS E DISCUSSÃO}

\subsection{Solução Nutritiva}

\subsubsection{Consumo}

O consumo de solução nutritiva durante o período do experimento foi de 277, 285 e 354 litros, para os tratamentos reposição diária com água (RVA), reposição diária com solução nutritiva (RVS) e renovação total diária da solução nutritiva (RTD), respectivamente. O comportamento do consumo de solução no período do transplante até a colheita pode ser observado na figura 2 .

O efeito diferencial no consumo pode ser atribuído às concentrações das soluções nutritivas (Burrage \& Varley, 1980). Quando a concentração da solução é menor há um maior desenvolvimento do sistema radicular (é o caso da RVA) para compensar a menor quantidade de nutrientes disponível. A transpiração aumenta até uma determinada relação entre a superfície das raízes e a área foliar, mas ultrapassado esse limite a transpiração estabiliza-se (Biaglogwski, 1936). Essa relação não foi estudada nesse experimento, porém a relação material fresco (MF) das raízes $(\mathrm{g}) /$ material fresco $(\mathrm{MF})$ da parte aérea $(\mathrm{g})$ foi determinada e os seguintes resultados foram obtidos: 0,$16 ; 0,18$ e 0,12 (médias gerais dos tratamentos estudados) para RVA, RVS e RTD, respectivamente. A menor relação de MF de raízes/de MF de parte aérea na $\mathrm{RTD}$, refletiu-se num consumo de solução nutritiva muito maior em relação aos demais tratamentos. Supõe-se 
que o valor dessa relação na RTD estava abaixo do limite de estabilização da transpiração estudado por Biaglogwski (1936) e que na RVA e na RVS os valores encontrados para essa relação estavam acima desse limite. Isso explica porque nesses tratamentos houve um consumo semelhante de solução nutritiva embora tivessem valores da relação diferentes. O comportamento dessa relação para a alface necessita ser melhor esclarecido, em um estudo específico.

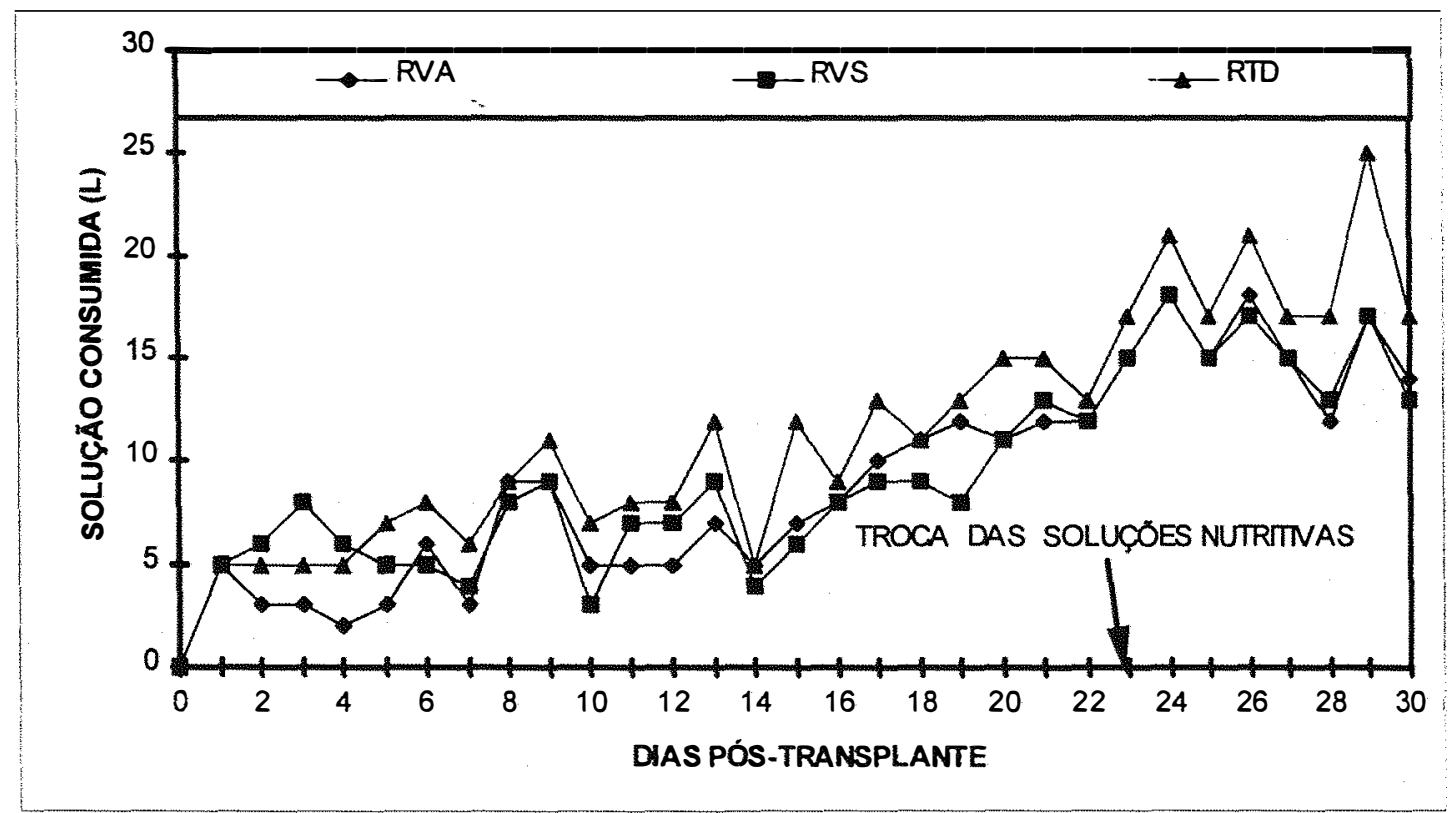

Figura 2. Volume consumido de solução nutritiva pelas plantas de alface cultivar Verônica (por 135 plantas), em "NFT", em cada manejo da solução.

\subsection{2. $\mathrm{CE}$ e pH}

Na figura 3 pode-se observar que na solução do tratamento RVA, a CE diminuiu de 2,7 para $1,0 \mathrm{mS} \mathrm{cm}{ }^{-1}$, no período de 0 a 22 dias pós-transplante (dpt). Nesse tratamento o coeficiente de correlação linear entre as concentrações de nutrientes e a CE obtida foi de 0,9. Assim sendo, a queda na CE pode ser atribuída a diminuição da concentração dos nutrientes na solução 
nutritiva como consequiência da absorção pela alface, além do efeito de diluição causado pela adição diária de água de torneira. A água adicionada contribuiu com o fornecimento de uma certa quantidade de nutrientes mas que não foi suficiente para evitar a queda da $\mathrm{CE}$. Após a troca das soluções, a $\mathrm{CE}$ caiu 2,6 vezes mais rapidamente que antes da troca (no $7^{0}$ dia de uso a $\mathrm{CE}$ atingiu $1,4 \mathrm{mS} \mathrm{cm}^{-1}$ ). Além de ser a semana anterior à colheita, portanto uma fase de rápido crescimento, as plantas podem ter sofrido deficiência de nutrientes na fase anterior à troca e portanto, procuraram compensar, absorvendo mais rapidamente os nutrientes da solução nova.

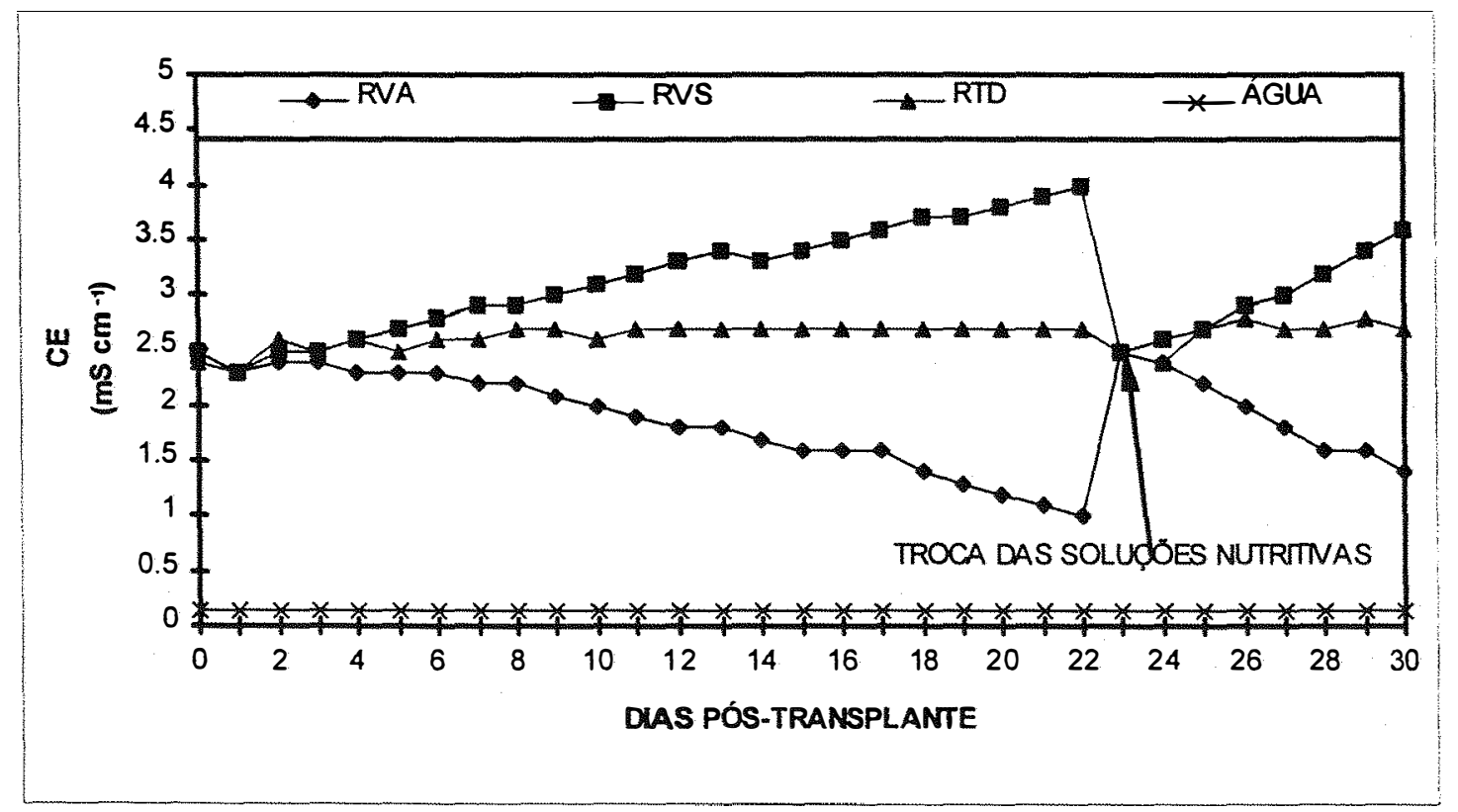

Figura 3. Comportamento da $\mathrm{CE}$ da água e da solução nutritiva manejada de três formas, para a alface cultivar Verônica, em "NFT".

A CE aumentou de 2,7 para $4,0 \mathrm{mS} \mathrm{cm}^{-1}$, na solução nutritiva no tratamento da RVS (Figura 3), no período de 0 aos $22 \mathrm{dpt}$. Após a troca das soluções verificou-se novamente um incremento na $\mathrm{CE}$ e aos 7 dias de uso da solução, a CE atingiu o valor de $3,6 \mathrm{mS} \mathrm{cm}^{-1}$, aumentando assim 2,3 vezes mais 
rapidamente que no período anterior. Esse aumento da $\mathrm{CE}$ mais rápido, pode ser atribuído a maior quantidade de água consumida pela planta nesse período, em função do crescimento mais rápido e do desenvolvimento maior. No entanto, o coeficiente de correlação linear entre a soma das concentrações dos nutrientes analisados na solução e a CE no período todo foi de 0,08 , para esse tratamento. Isso sugere que a $\mathrm{CE}$ pode ter sido afetada por um outro fator (que não foi a concentração dos nutrientes analisados) ou que podem ter havido problemas nas análises químicas dos nutrientes contidos na solução nutritiva para esse tratamento.

Na solução do tratamento RTD, a CE manteve-se praticamente constante no valor de $2,7 \mathrm{mS} \mathrm{cm}^{-1}$, do transplante até a colheita. O coeficiente de correlação linear obtido entre a soma das concentrações de nutrientes em solução e a CE foi de 0,49 , demonstrando que para esse tratamento, assim como para o anterior, não foi obtida uma boa correlação entre a concentração de nutrientes e a $\mathrm{CE}$, pelos mesmos motivos expostos.

Quanto ao comportamento do pH (Figura 4) nos manejos da solução, foi observada uma queda gradual do valor do $\mathrm{pH}$ inicial $(6,0)$ para 4,2 , até o $8^{\circ} \mathrm{dpt}$. Essa queda pode ser atribuída à capacidade de absorção preferencial de da alface, que absorveu maiores proporções de cátions (amônio, potássio, cálcio, magnésio, etc.) e de $\mathrm{N}-\mathrm{NH}_{4}{ }^{+}$em relação ao $\mathrm{N}-\mathrm{NO}_{3}{ }^{-}$. Absorvendo outros cátions e proporções maiores de $\mathrm{N}^{-\mathrm{NH}_{4}}{ }^{+}$a alface liberou mais $\mathrm{H}^{+}$, causando a queda do $\mathrm{pH}$. Essa queda inicial do $\mathrm{pH}$ foi semelhante à observada por Clark (1982). Após esse período de queda inicial dos valores, o $\mathrm{pH}$ comportou-se diferentemente nos tratamentos.

$\mathrm{Na} \mathrm{RVA}$, o $\mathrm{N}-\mathrm{NH}_{4}^{+}$pode ter sido totalmente absorvido até o $8^{\circ} \mathrm{dpt}$, passando a alface a absorver somente $\mathrm{N}_{-} \mathrm{NO}_{3}{ }^{-}$a partir desse momento e liberando 
$\mathrm{OH}^{+}$e/ou $\mathrm{HCO}_{3}{ }^{-}$. Ocorreu assim, um aumento do valor do $\mathrm{pH}$ até 7,0 , do $9^{9}$ até o $16^{0} \mathrm{dpt}$. A solução manteve-se com valor de $\mathrm{pH}$ constante nesse valor até a substituição (23 dpt). Esse resultado também concorda com o obtido por Clark (1982). Após a roca da solução, o valor do pH voltou a aumentar, porém mais rapidamente, até estabilizar-se em 7,0, à partir dos 3 dias de uso. A adição diária de água com pH 7,0 deve ter contribuído também para a elevação dos valores de $\mathrm{pH}$.

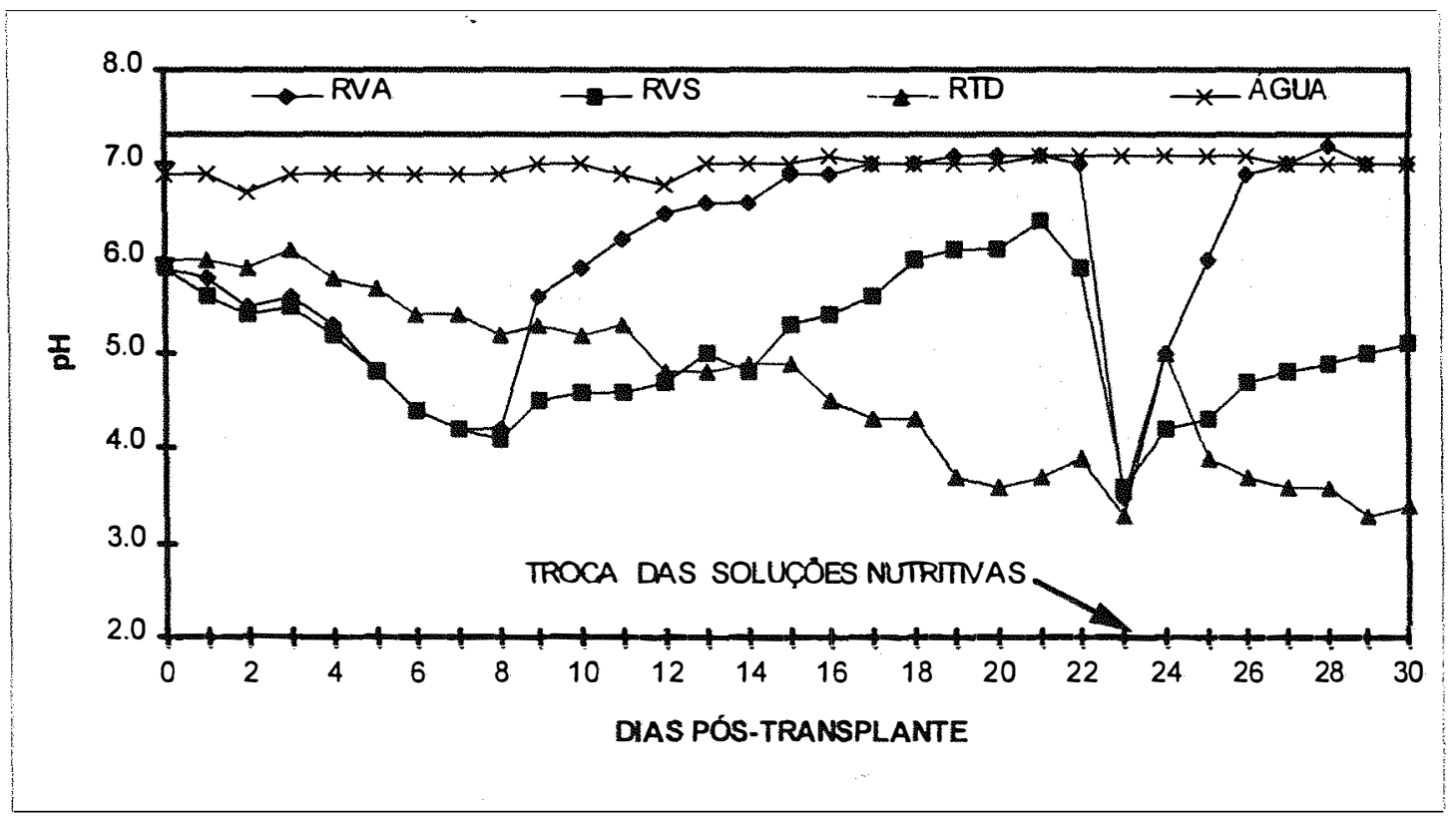

Figura 4. Comportamento do $\mathrm{pH}$ da água e da solução nutritiva manejada das três formas com ajuste diário do valor de $\mathrm{pH}$ a 6,0, para a alface cultivar Verônica, em "NFT".

$\mathrm{Na}$ RVS, a queda dos valores de $\mathrm{pH}$ até o $8^{\mathfrak{Q}} \mathrm{dpt}$, foi conseqüência também da absorção do $\mathrm{N}-\mathrm{NH}_{4}^{+}$presente na solução inicial, da mesma forma como observou-se na RVA. A partir do $8^{\varrho}$ dpt observou-se uma elevação dos valores de $\mathrm{pH}$ porém, essa elevação foi mais lenta que na RVA. Isso justifica-se porque a reposição diária do volume com solução (que continha nutrientes nas 
mesmas proporções da solução inicial) forneceu $\mathrm{N}_{-} \mathrm{NH}_{4}{ }^{+}$. Como as quantidades de solução repostas foram relativamente pequenas, a alface absorveu inicialmente em maior proporção as quantidades de $\mathrm{N}-\mathrm{NH}_{4}{ }^{+}$adicionadas até esgotá-las, passando a absorver mais $\mathrm{N}^{-\mathrm{NO}_{3}}{ }^{-}$para completar as necessidades diárias de nitrogênio. Assim, prevaleceu o efeito da elevação dos valores do $\mathrm{pH}$ causado pela absorção do $\mathrm{N}^{-\mathrm{NO}_{3}}{ }^{-}$mas, esse efeito foi diminuído pela ação dos íons $\mathrm{H}^{+}$liberados durante a absorção do $\mathrm{N}-\mathrm{NH}_{4}{ }^{+}$, como foi explicado por Clark (1982).

Após a substituição das soluções, aos 23 dias, os valores de $\mathrm{pH}$ continuaram aumentando na RVA e diminuindo na RVS. Porém, assim como para a CE, esses efeitos ocorreram com maior velocidade nessa fase do ciclo, e podem ser atribuídos ao crescimento mais rápido da alface que afetou mais rapidamente esse atributo da solução nutritiva.

No tratamento RTD, o comportamento dos valores de $\mathrm{pH}$ caracterizou-se por uma queda gradativa do transplante até a colheita. A renovação diária da solução manteve uma relação de 1 parte de $\mathrm{NH}_{4}{ }^{+}$para 9,88 partes de $\mathrm{NO}_{3}{ }^{-}$que favoreceu a queda dos valores de $\mathrm{pH}$ no decorrer de todo o período observado. Esse efeito foi também observado por Jones Jr. (1983) e Clark (1982).

\subsubsection{Nutrientes}

É importante lembrar que, para se ter mais segurança nas tomadas de decisão no manejo da solução nutritiva, é preciso comparar os resultados obtidos para os nutrientes nas análises da solução com os resultados obtidos nas análises das plantas. 


\subsubsection{Macronutrientes}

O nitrogênio é um dos elementos mais sujeito a diferenças entre a redução das quantidades em solução e as quantidades absorvidas pelas plantas (Heinen et al.,1991). Esse elemento facilmente sofre a desnitrificação e/ou a imobilização por microorganismos.

$\mathrm{Na}$ figura 5 pode-se observar que as concentrações caíram rapidamente, na RVA e na RVS, chegando a 0 no $18^{\circ} \mathrm{dpt}$. Na RVA, no $8^{\circ} \mathrm{dpt}$ as concentrações se equipararam às da água e para a RVS isso aconteceu aos $12 \mathrm{dpt}$. Isso sugere que a alface tem uma grandè demanda por nitrogênio na fase inicial $( \pm 10 \mathrm{DPT})$. Na RTD, onde a concentração dos nutrientes foi mantida constante, houve uma diminuição diária na concentração de nitrogênio da solução nutritiva, sendo menor até o $18^{\circ} \mathrm{dpt}$ e acentuando-se mais até a colheita. A concentração do nitrogênio na solução diminui com a evolução do ciclo da cultura.

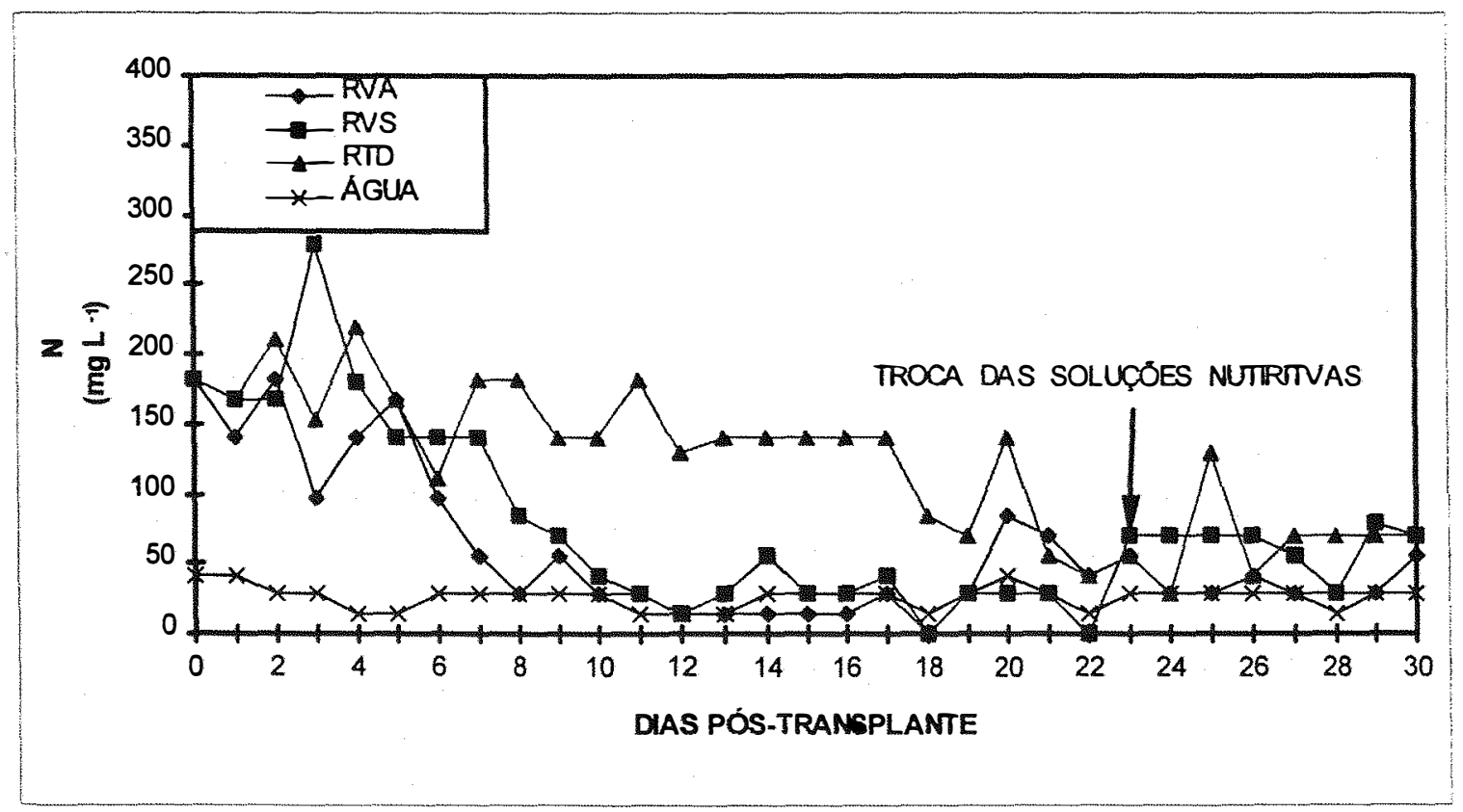

Figura 5. Comportamento das concentrações de nitrogênio na água e nas soluções nutritivas manejadas das três formas, para alface cultivar Verônica, em "NFT", do transplante até a colheita. 


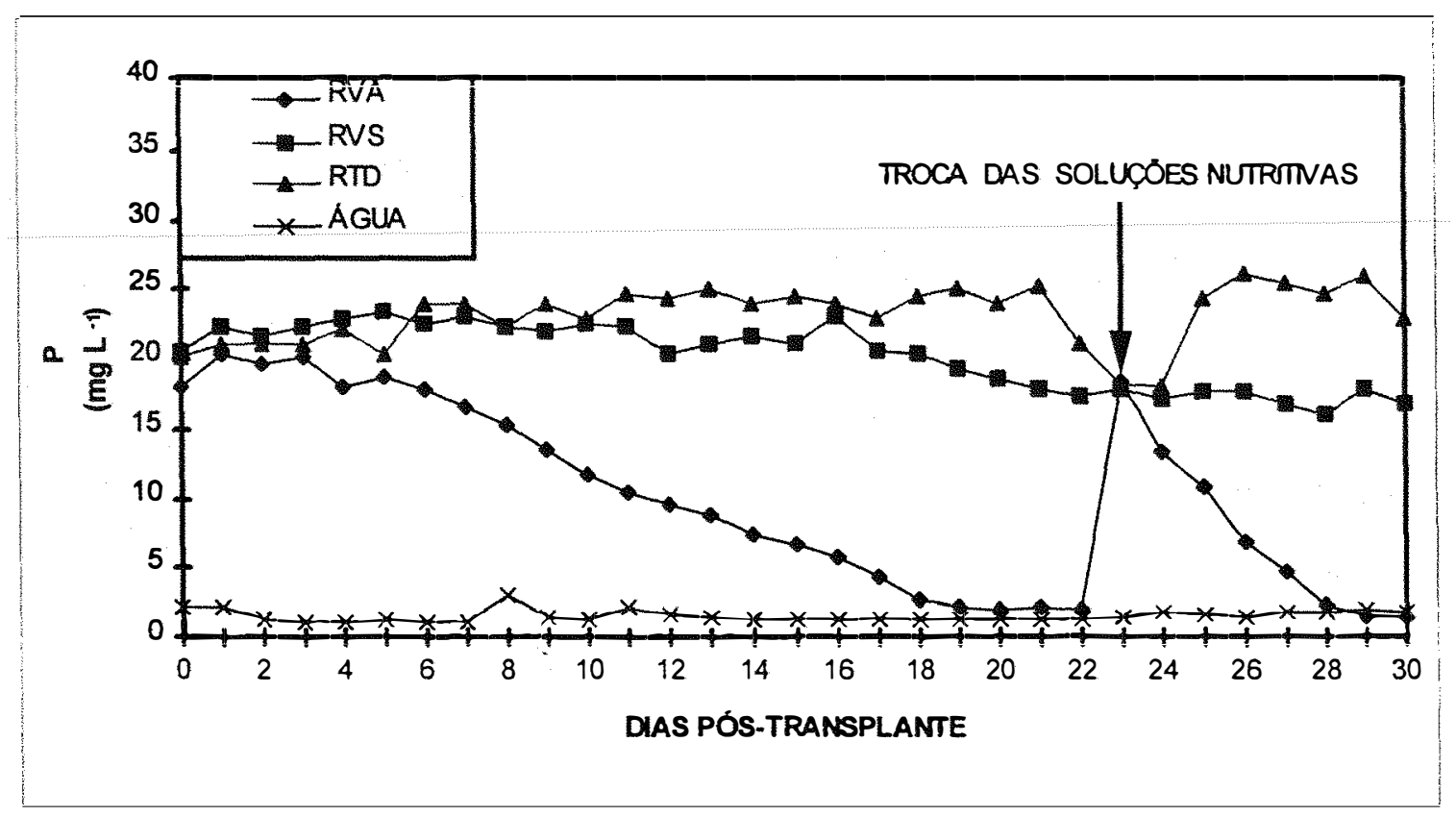

Figura 6. Comportamento das concentrações de fósforo na água e nas soluções nutritivas manejadas três formas, para alface cultivar Verônica, em "NFT", do transplante até a colheita.

A concentração do fósforo manteve-se estável até o $4^{0} \mathrm{dpt}$, em todos os tratamentos (Figura 6). A partir daí ocorreu uma queda rápida para a RVA, chegando até uma concentração semelhante à da água no $18^{0} \mathrm{dpt}$. Quanto ao comportamento da concentração após a troca da solução, ela caiu ao valor semelhante à da água em apenas 5 dias, supondo-se ser uma conseqüência da tentativa da planta em suprir as deficiências adquiridas anteriormente, nesse tratamento. Para a RVS e RTD as concentrações mantiveram-se estáveis e semelhantes até o $10^{\circ} \mathrm{dpt}$. Depois disso a concentração começou a cair lentamente na RVS e a aumentar na RTD. Esse comportamento manteve-se mesmo após a troca das soluções. 


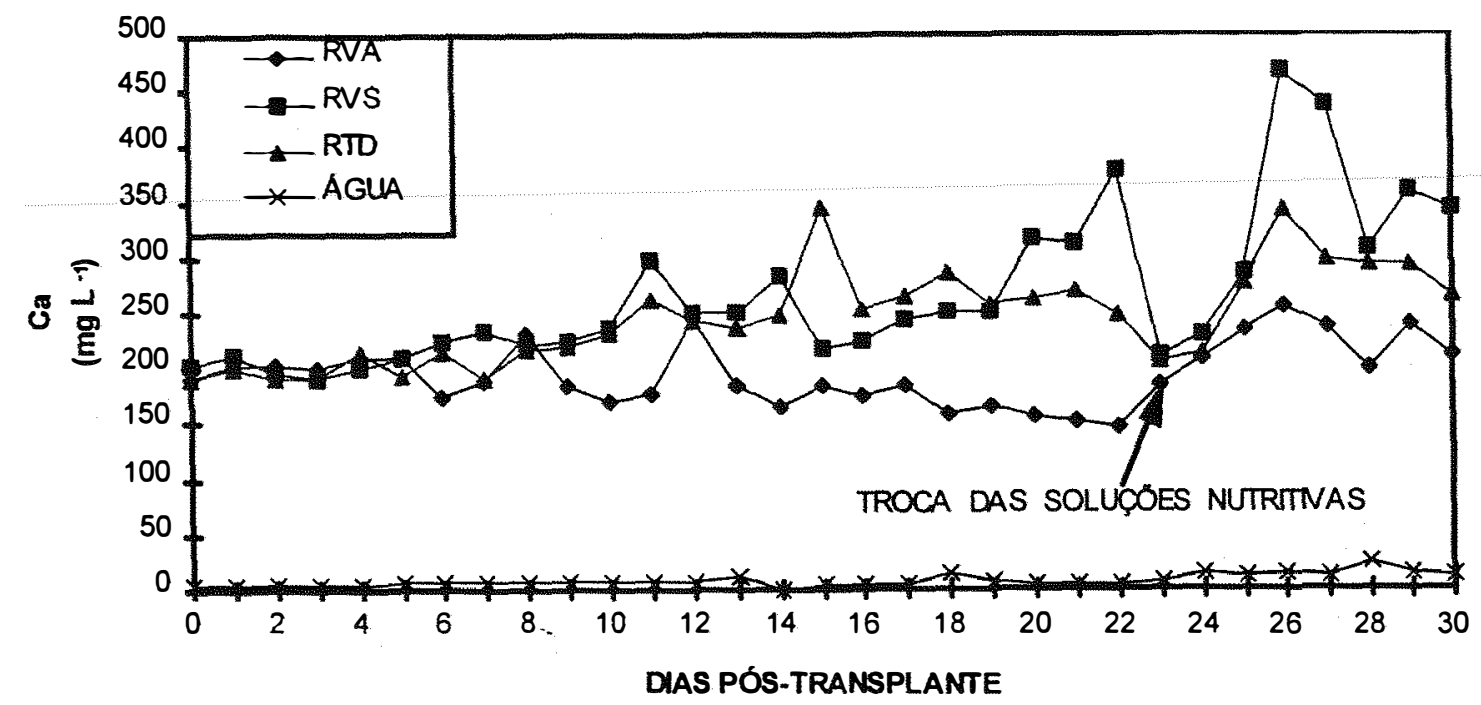

Figura 7. Comportamento das concentrações de potássio na água e nas soluções nutritivas manejadas das três formas, para alface cultivar Verônica, em "NFT", do transplante até a colheita.

A concentração de potássio apresentou uma queda acentuada no tratamento RVA, vindo a assemelhar-se à da água de reposição, no $19^{0} \mathrm{dpt}$ (Figura 7). O potássio praticamente chegou à concentração zero nesse tratamento, nos dias antecedentes à troca $(19-22 \mathrm{dpt})$, uma vez que a água forneceu quantidades desprezíveis desse elemento. Após a troca da solução, essa queda foi mais rápida, levando apenas 7 dias para que a concentração caísse ao valor da água. Para a RVS e RTD, obteve-se um comportamento estável e semelhante durante todo o ciclo.

Para o cálcio, a redução na concentração foi lenta em todos os tatamentos, sendo que até o $8^{\mathfrak{o}} \mathrm{dpt}$, ela praticamente ficou estável e semelhante à inicial. Isso sugere que a absorção desse elemento pela alface seja mais tardia (Figura 8). Na RVA, ocorreu uma redução a partir do $8^{0} \mathrm{dpt}$, mas ela foi menor 
quando comparada à que ocorreu com os macronutrientes primários, para o mesmo tratamento.

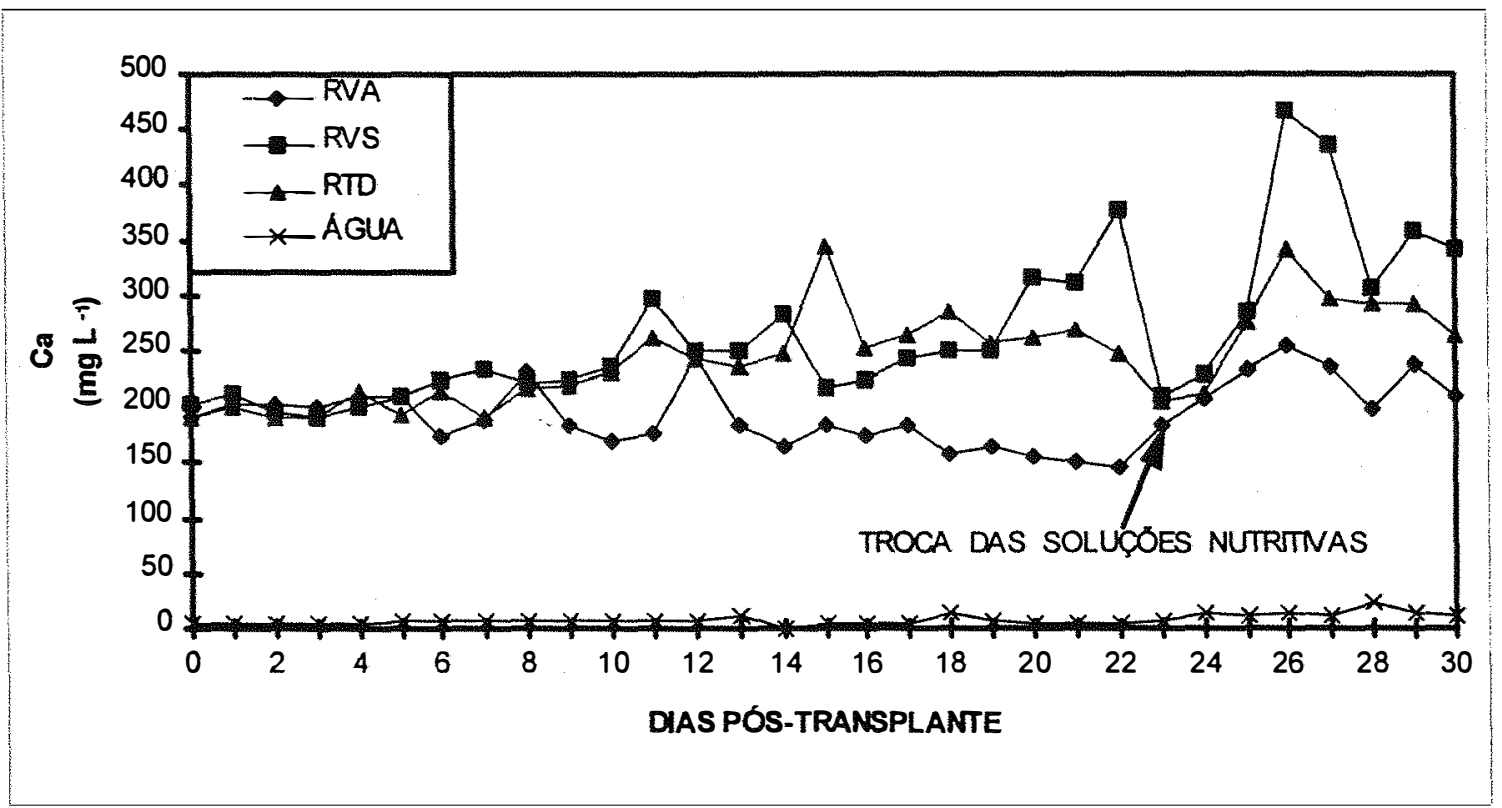

Figura 8. Comportamento das concentrações de cálcio na água e nas soluções nutritivas manejadas das três formas, para alface cultivar Verônica, em "NFT", do transplante até a colheita.

Na RVS e na RTD, houve um leve incremento após o $8^{\circ} \mathrm{dpt}$, sendo que ora a concentração foi maior num, ora noutro desses tratamentos. A partir do $18^{0}$ dpt , iniciou um acúmulo maior de cálcio na RVS e isso continuou acontecendo após a troca da solução, sendo que nesse período, esse acúmulo também ocorreu na RTD. Na RVA, após a troca, a concentração praticamente manteve-se estável.

O magnésio comportou-se de forma semelhante ao cálcio, sendo que até o $9^{0} \mathrm{dpt}$, a concentração mostrou-se estável e semelhante nos três tratamentos (Figura 9). A partir do $8^{\varrho}$ dpt, percebeu-se uma redução lenta na concentração do magnésio na RVA, mantendo-se esse ritmo após a troca da solução. Na RVS e na RTD, a partir do $9^{0}$ dpt aumentou a concentração e esse aumento foi bem maior 
na RVS. Após a troca, a concentração continuou incrementando na RVS. Na RTD percebeu-se uma redução gradual do $22^{\circ} \mathrm{dpt}$ até a colheita.

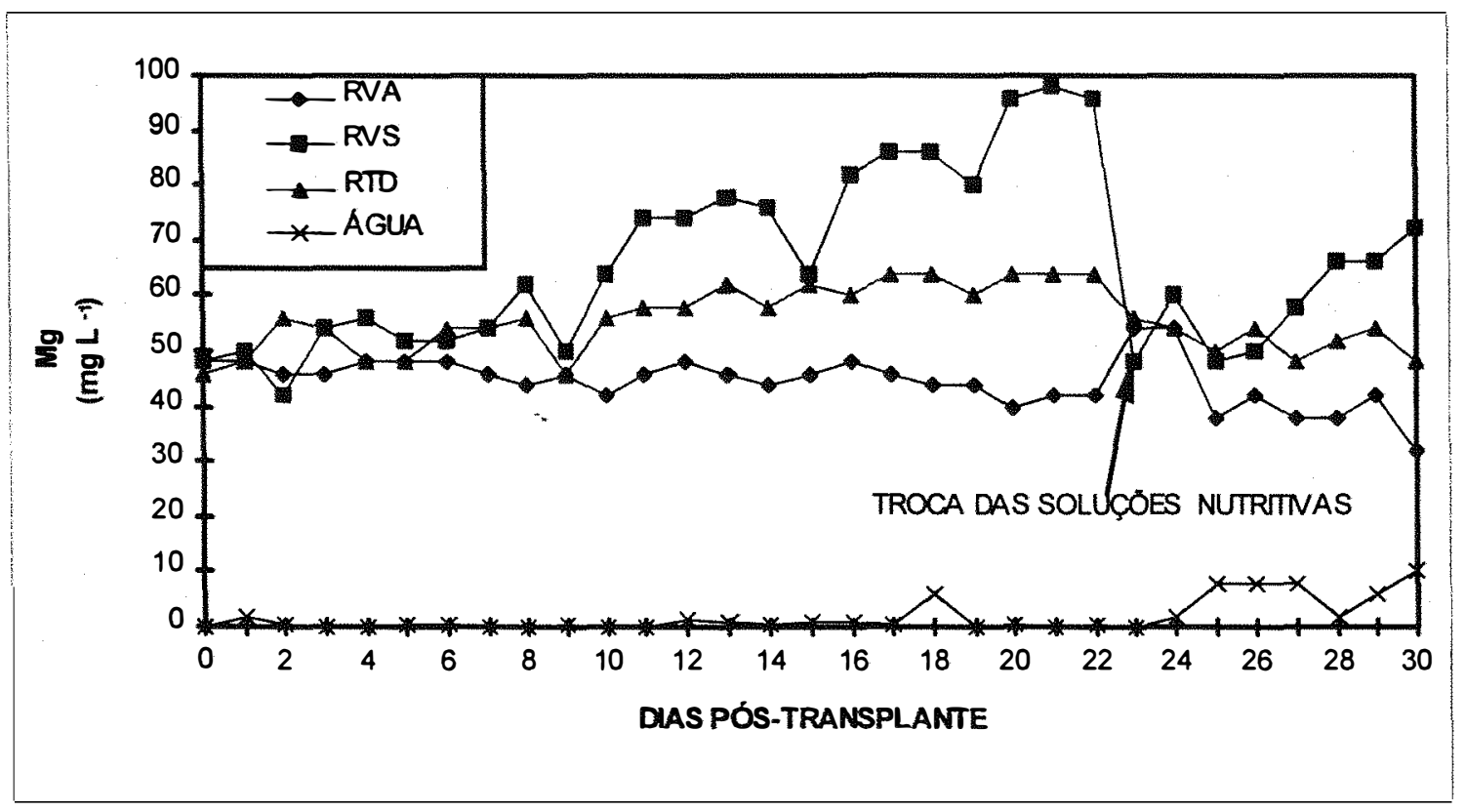

Figura 9. Comportamento das concentrações do magnésio na água e nas soluções nutritivas manejadas das três formas, para alface cultivar Verônica, em "NFT", do transplante até a colheita.

A concentração de enxofre comportou-se de modo semelhante nos três tratamentos, até 7-8 dpt (Figura 10). Até os $4 \mathrm{dpt}$ aumentou, para depois cair. A

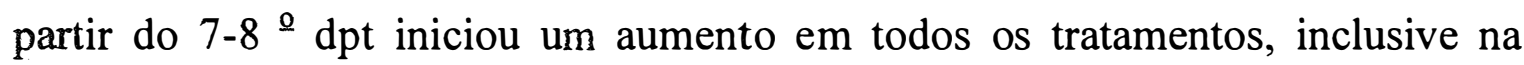
RVA, o qual pode ser justificado pelo elevado teor de enxofre na água de torneira. O incremento foi maior na RVS, seguido da RTD e da RVA. Depois da troca das soluções houve uma queda geral até os $25 \mathrm{dpt}$, para depois voltar a aumentar na RVS e RTD e reduzir-se lentamente na RVA. 


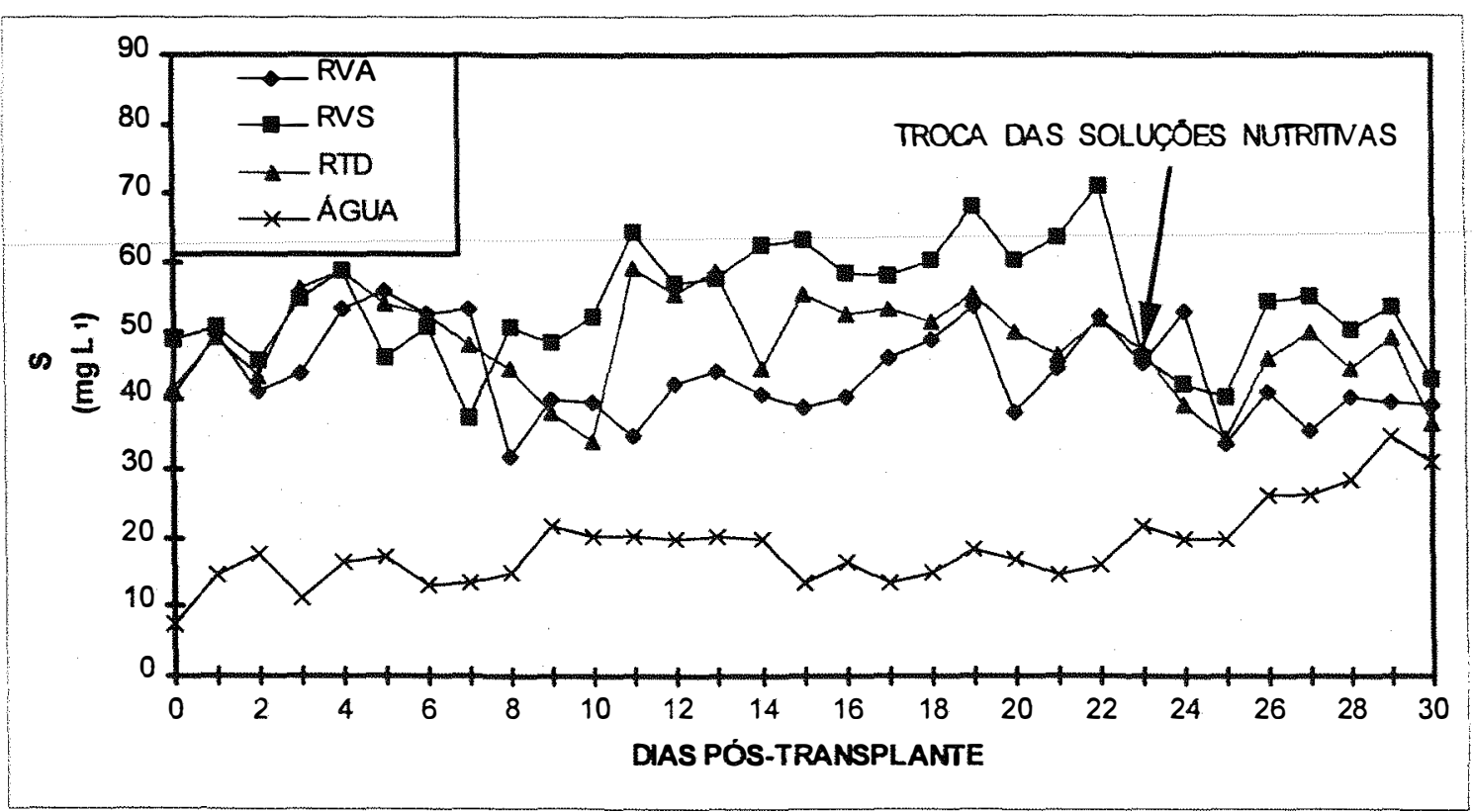

Figura 10. Comportamento das concentrações de enxofre na água e nas soluções nutritivas manejadas das três formas, para alface cultivar Verônica, em "NFT", do transplante até a colheita.

\subsubsection{Micronutrientes}

O boro apresentou uma queda gradual e lenta em suas concentrações na RVA, um incremento progressivo mas lento na RVS e um comportamento variável na RTD (Figura 11). Esses comportamentos se mantiveram assim durante todo o ciclo na RVA e na RVS. As quantidades fornecidas na solução inicial parecem ter sido suficientes para suprir as exigências de todo o ciclo da alface, sem necessidade de reposição. 


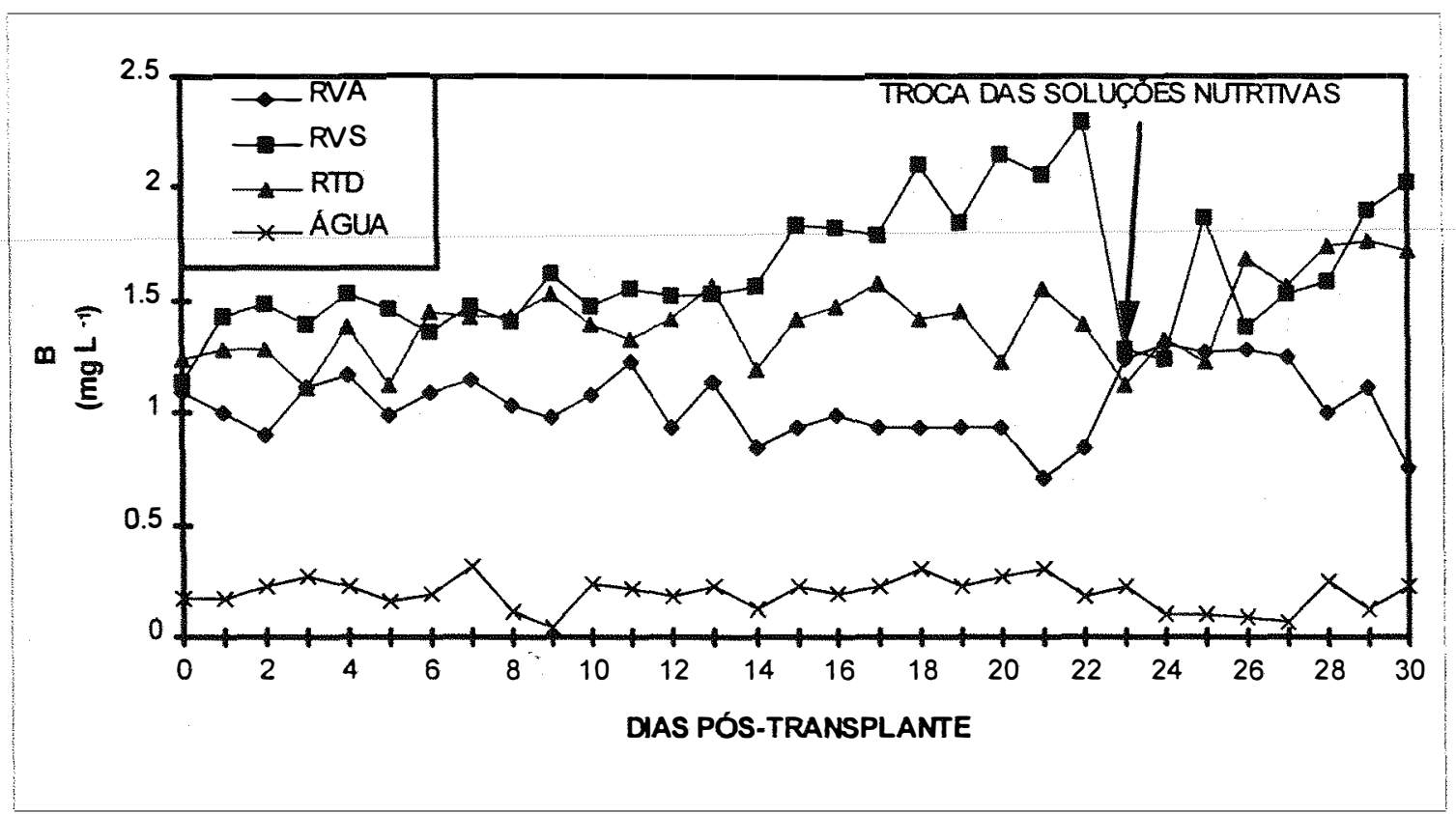

Figura 11. Comportamento das concentrações de boro na água e nas soluções nutritivas manejadas das três formas, para alface cultivar Verônica, em "NFT", do transplante até a colheita.

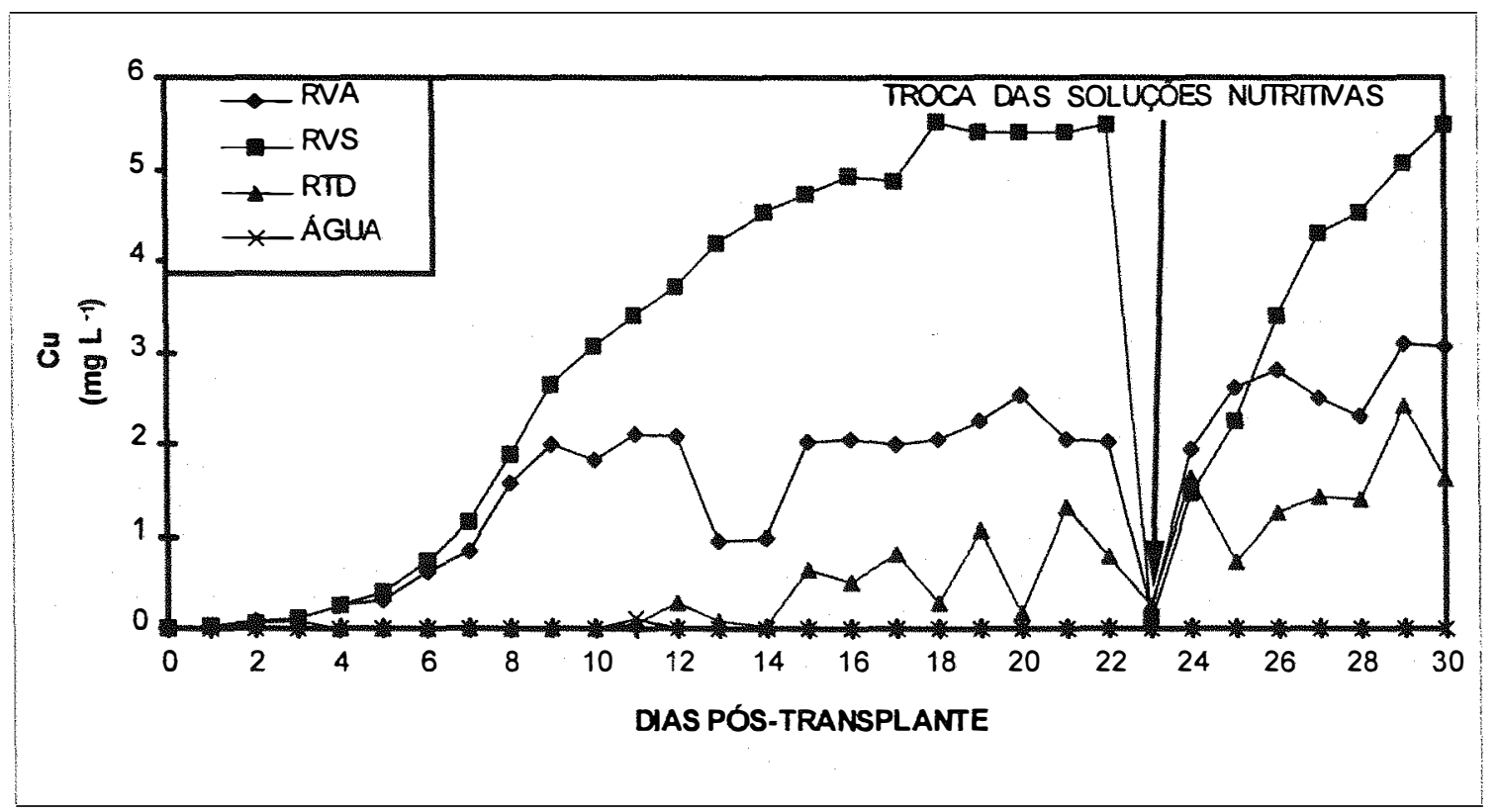

Figura 12. Comportamento das concentrações de cobre na água e nas soluções nutritivas manejadas das três formas, para alface cultivar Verônica, em "NFT", do transplante até a colheita. 
A concentração de cobre na RVA, manteve-se baixa e estável até o $3^{ }$ dpt, quando aumentou muito até o final do ciclo (Figura 12). Supõe-se tratar de contaminações externas, porque na água adicionada praticamente não havia cobre que pudesse justificar esses aumentos. Na RVS, a concentração aumentou muito durante todo o ciclo da alface. Na RTD, a concentração manteve-se estável até os $14 \mathrm{dpt}$, quando iniciaram aumentos e reduções seguidos de modo a aumentar gradativamente até o final do ciclo, que pode em parte ser atribuído ao maior consumo de água nesse tratamento, que nos demais (Figura 2).

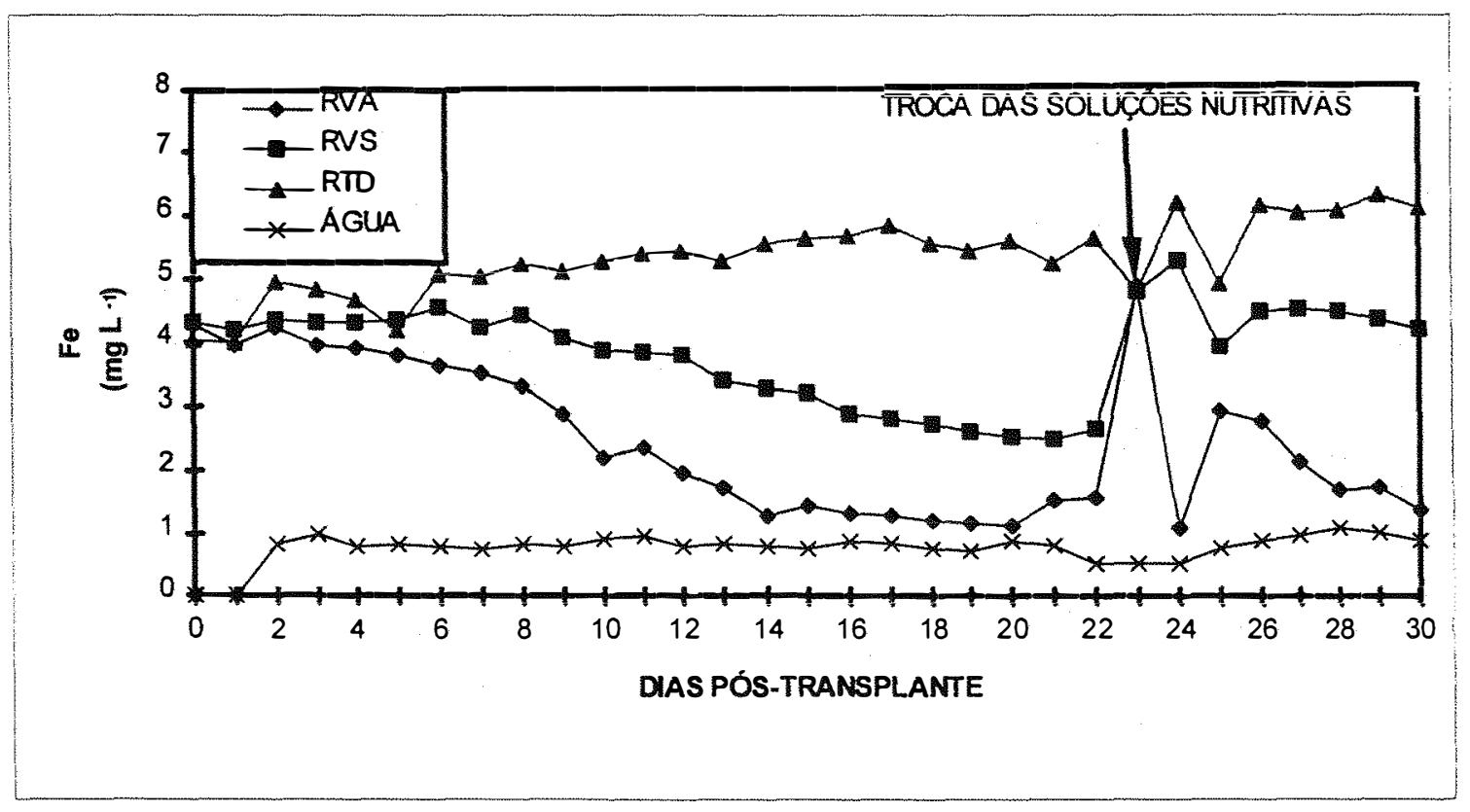

Figura 13. Comportamento das concentrações de ferro na água e nas soluções nutritivas manejadas das três formas, para alface cultivar Verônica, em "NFT", do transplante até a colheita.

A concentração de ferro na RVA diminuiu rapidamente até o $14^{\varrho} \mathrm{dpt}$ passando a uma fase de redução da concentração mais lenta até $20^{\circ} \mathrm{dpt}$. Na RVS essa redução foi menor e na RTD manteve-se praticamente estável durante todo o período estudado (Figura 13). A concentração de ferro observada na RVA chegou 
muito próxima ao valor de concentração na água no $14^{\varrho} \mathrm{dpt}$ mas somente atingiu valor de concentração semelhante ao da água no $20^{\circ} \mathrm{dpt}$.

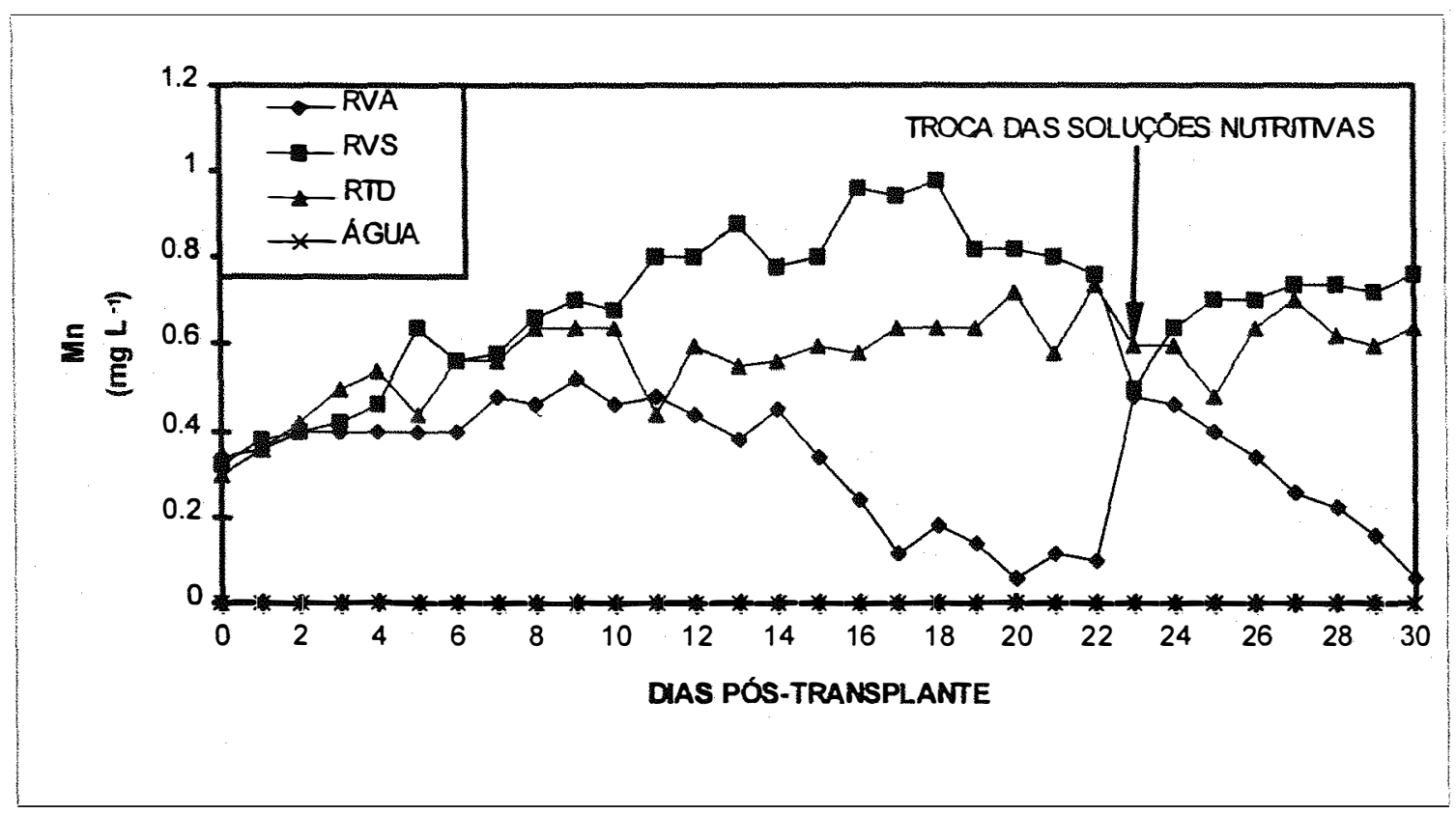

Figura 14. Comportamento das concentrações de manganês na água e nas soluções nutritivas manejadas das três formas, para alface cultivar Verônica, em "NFT", do transplante até a colheita.

A concentração de manganês na RVA foi constante até o $14^{0} \mathrm{dpt}$, atingindo a mesma concentração da água no $20^{\circ}$ dpt (Figura 14). Na RVS, essa concentração aumentou até o $18^{0} \mathrm{dpt}$, diminuindo em seguida, para estabilizar-se até a colheita. Na RTD, a concentração manteve-se constante por todo o ciclo, sugerindo que a absorção diária foi pequena e insuficiente para afetar a concentração de manganês na solução de um dia a outro.

O zinco, assim como o cobre, apresentou um comportamento inesperado na RVA, aumentando sua concentração mesmo sem haver grandes quantidades desse elemento na água de reposição (Figura 15). A concentração de zinco aumentou na RVS no decorrer do ciclo e esse aumento foi mais rápido após a 
troca da solução. Na RTD, a concentração manteve-se praticamente constante vindo a aumentar a partir do $18^{\circ} \mathrm{dpt}$, o que pode ser justificado pelo aumento no consumo de água nesse período.

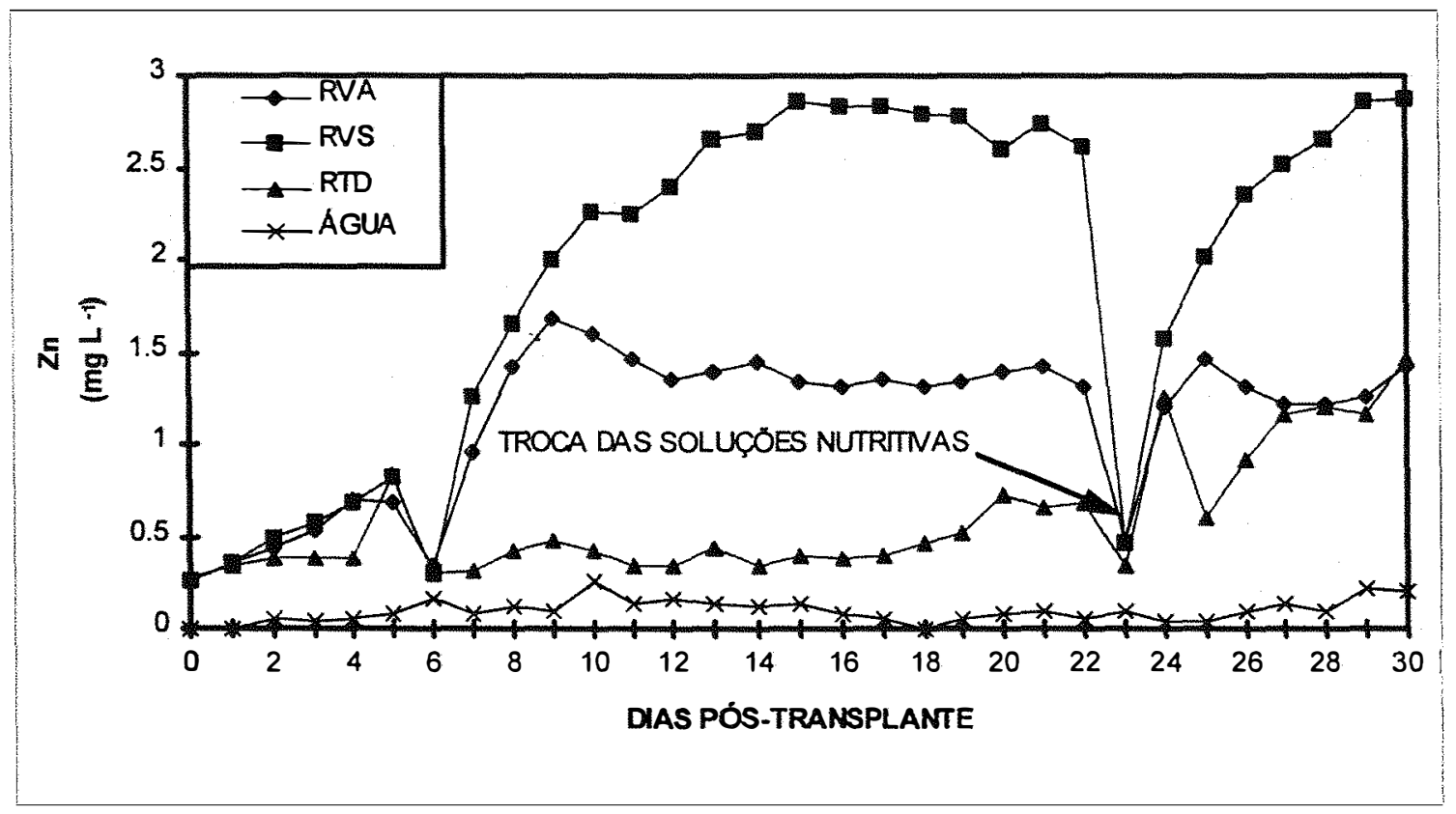

Figura 15. Comportamento das concentrações de zinco na água e nas soluções nutritivas manejadas das três formas, para alface cultivar Verônica, em "NFT", do transplante até a colheita.

\subsubsection{Recomendações}

Os macronutrientes, de modo geral, mantiveram-se estáveis quanto a sua concentração na RVS e na RTD (Figura 16). Na RVA houve uma queda geral na concentração dos macronutrientes. Pode-se sugerir que no caso de adotar esse tipo de manejo de solução nutritiva, adições de nutrientes sejam feitas para elevá-los aos níveis iniciais, quando a sua concentração assemelhar-se aos valores contidos na água ou até antes disso ocorrer, mas isso precisa ser melhor esclarecido em outro trabalho. Supondo que a concentração dos nutrientes na solução fosse 
elevada à concentração inicial quando a concentração desses se assemelhasse às concentrações contidas na água, para o nitrogênio seria aos $8 \mathrm{dpt}$ e para o fósforo e o potássio seria aos $18 \mathrm{dpt}$. As quantidades de cálcio, magnésio e enxofre fornecidas nas soluções iniciais foram suficientes para garantir a constância dos seus valores de concentração em solução até os $23 \mathrm{dpt}$, o que dispensaria adições desses elementos, dentro desse período.

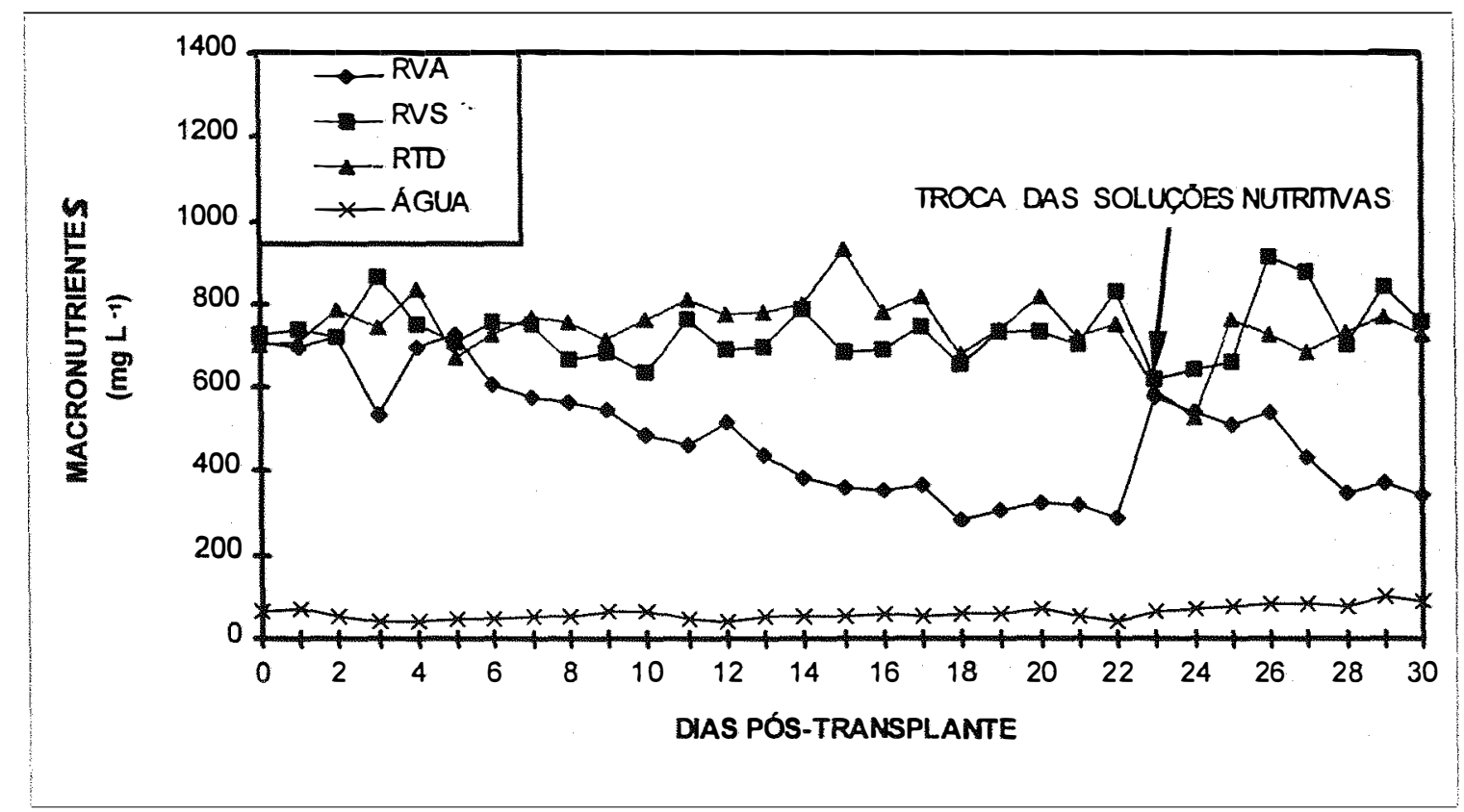

Figura 16. Comportamento das somas das concentrações dos macronutrientes na água e nas soluções nutritivas manejadas das três formas, para alface cultivar Verônica, em "NFT", do transplante até a colheita.

Para o conjunto dos micronutrientes, de modo geral, houve um comportamento semelhante até o $11^{0} \mathrm{dpt}$ na RVA e RTD (Figura 17). A partir desse momento, houve uma redução maior desses elementos e na RVA percebe-se uma nítida queda. As quantidades adicionadas via solução na RVS acumularamse na solução demostrando que não é necessária a reposição em grandes quantidades desses elementos. Recomenda-se então que apenas o ferro e o 
manganês sejam elevados ao nível inicial aos $20 \mathrm{dpt}$. Os demais micronutrientes não necessitariam ser repostos pelo menos até os $23 \mathrm{dpt}$.

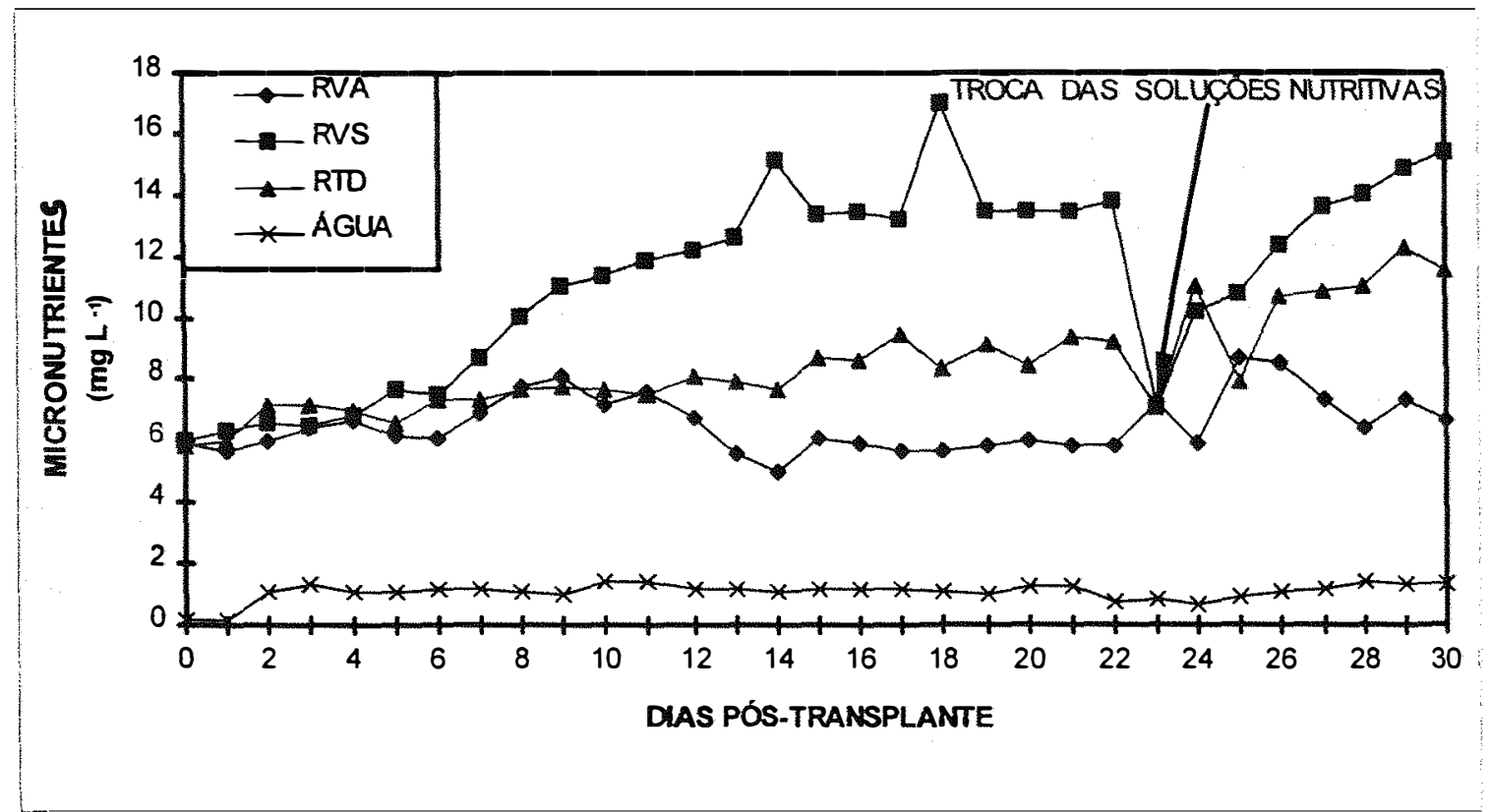

Figura 17. Comportamento das somas das concentrações dos micronutrientes na água e nas soluções nutritivas manejadas das três formas, para alface cultivar Verônica, em "NFT", do transplante até a colheita.

\subsection{Alface}

\subsubsection{Produção}

\subsubsection{Raizes}

Para a produção de MF não foi observada diferença significativa até $15 \mathrm{dpt}$ entre os tratamentos (Tabela 4). Aos $20 \mathrm{dpt}$, os tratamentos começaram a se diferenciar. Aos 25 dpt e na colheita, a produção na RVA e na RVS diferiu significativamente da RTD. Faquin et al. (1996) obtiveram valor de MF de raízes 
maiores aos obtidos neste experimento com a mesma cultivar no $30^{\mathfrak{Q}} \mathrm{dpt}$, porém cabe salientar que esses autores utilizaram duas plantas por furo ao invés de uma.

A produção de MF das raízes de alface teve um aumento linear progressivo em função do tempo, para a RVA e RTD (Figura 18 A). O incremento foi mais rápido na RVA que na RTD. Na RVS a produção passou por uma fase estável dos 10-15 dpt, passando a aumentar rapidamente dos 15-20 dpt e praticamente estabilizando dos 25-30 dpt, mas apresentando indícios de queda no final.

Tabela 4. Produção de material fresco e de material seco das raízes da alface cultivar Verônica, em "NFT", em cinco épocas de amostragem.

\begin{tabular}{|c|c|c|c|c|c|}
\hline \multirow{2}{*}{ MF $(\mathrm{g})^{* *}$} & \multicolumn{5}{|c|}{ DIAS POS-TRANSPLANTE } \\
\hline & 10 & 15 & 20 & 25 & 30 \\
\hline RTD & $3,01 \mathrm{a}$ & $6,57 \mathrm{a}$ & $10,65 \mathrm{~b}$ & $11,92 \mathrm{~b}$ & $14,41 \quad b$ \\
\hline RVS & $2,56 \mathrm{a}$ & $5,27 \mathrm{a}$ & $13,07 \mathrm{ab}$ & $19,13 \mathrm{a}$ & $19,80 \mathrm{a}$ \\
\hline RVA & $2,32 \mathrm{a}$ & $8,44 \mathrm{a}$ & $17,23 \mathrm{a}$ & $17,67 \mathrm{a}$ & 23,86 a \\
\hline \multicolumn{6}{|c|}{ DMS $=4,01$} \\
\hline \multicolumn{6}{|c|}{ MS $(g)^{\text {NS }}$} \\
\hline RTD & 0,16 & $\overline{0,38}$ & $\overline{0,61}$ & 0,64 & 0,90 \\
\hline RVS & 0,15 & 0,36 & 0,72 & 0,90 & 1,04 \\
\hline RVA & 0,14 & 0,49 & 0,83 & 0,84 & 1,05 \\
\hline
\end{tabular}

NS $\Rightarrow$ Interação não significativa entre tratamentos e épocas pelo teste $F(\alpha=0,05)$.

$\Rightarrow$ Interação significativa entre tratamentos e épocas pelo teste $F(\alpha=0,05)$.

Médias seguidas da mesma letra em cada sub-coluna de época, não diferem entre si pelo teste de Tukey $(\alpha=0,05)$.

Quanto à produção de MS, não houve interação entre os tratamentos e as épocas, sendo que analisando-se somente os tratamentos, a produção de MS na RTD foi menor que na RVA e na RVS (Anexo B3). Não se detectou diferença significativa entre a produção de MS da RVA e da RVS. Os resultados MS de raízes de alface, obtidos por Faquin et al. (1996) foram superiores aos encontrados nos tratamentos deste trabalho, pelo mesmo motivo já explicado para a MF. 
O comportamento da produção do MS das raízes é representada pela curva da figura $18 \mathrm{~B}$. Essa curva representa o comportamento dos três tratamentos, pois eles apresentaram comportamento similar em todas as épocas.

A percentagem de MS foi de 6,40;5,84;4,84; 4,79 e 4,41 nas cinco épocas de amostragem, para a RVA. Para a RVS foi de 5,89; 6,94; 5,51; 4,73 e $5,27 \%$ e para a RTD foi de 5,$49 ; 5,77 ; 5,76 ; 5,43$ e $6,25 \%$, respectivamente, nessas mesmas épocas. Pode-se observar que a percentagem de MS diminuiu no final do período na RVA e aumentou na RTD. Aos 20 e $25 \mathrm{dpt}$, todos os tratamentos tiveram uma qüeda na percentagem de material seco produzido, sugerindo que esse efeito foi causado por outros fatores, que os tratamentos.

A percentagem de MS das raízes na RVA de modo geral foi menor que nos demais tratamentos, sendo que na fase final do ciclo essas diferenças aumentaram. A redução gradativa na concentração dos macronutrientes (Figura 16), do transplante até a colheita, pode ter sido responsável por esse efeito. A RVS apresentou um comportamento intermediário provavelmente devido ao efeito tóxico causado pelos micronutrientes que se acumularam na solução (Figura 17) uma vez que pelas adições diárias de solução nutritiva, foram fornecidas quantidades maiores às das exigências da alface. A RTD teve os maiores valores para essa característica, provavelmente por ter sua concentração de nutrientes estável durante o ciclo, como conseqüência da troca diária da solução. Dessa forma não faltaram nutrientes para as plantas e nem acumularamse em excesso na solução. Além disso, a substituição diária deve ter eliminado substâncias tóxicas, que nos demais tratamentos podem ter-se acumulado e afetado a variável em questão. 


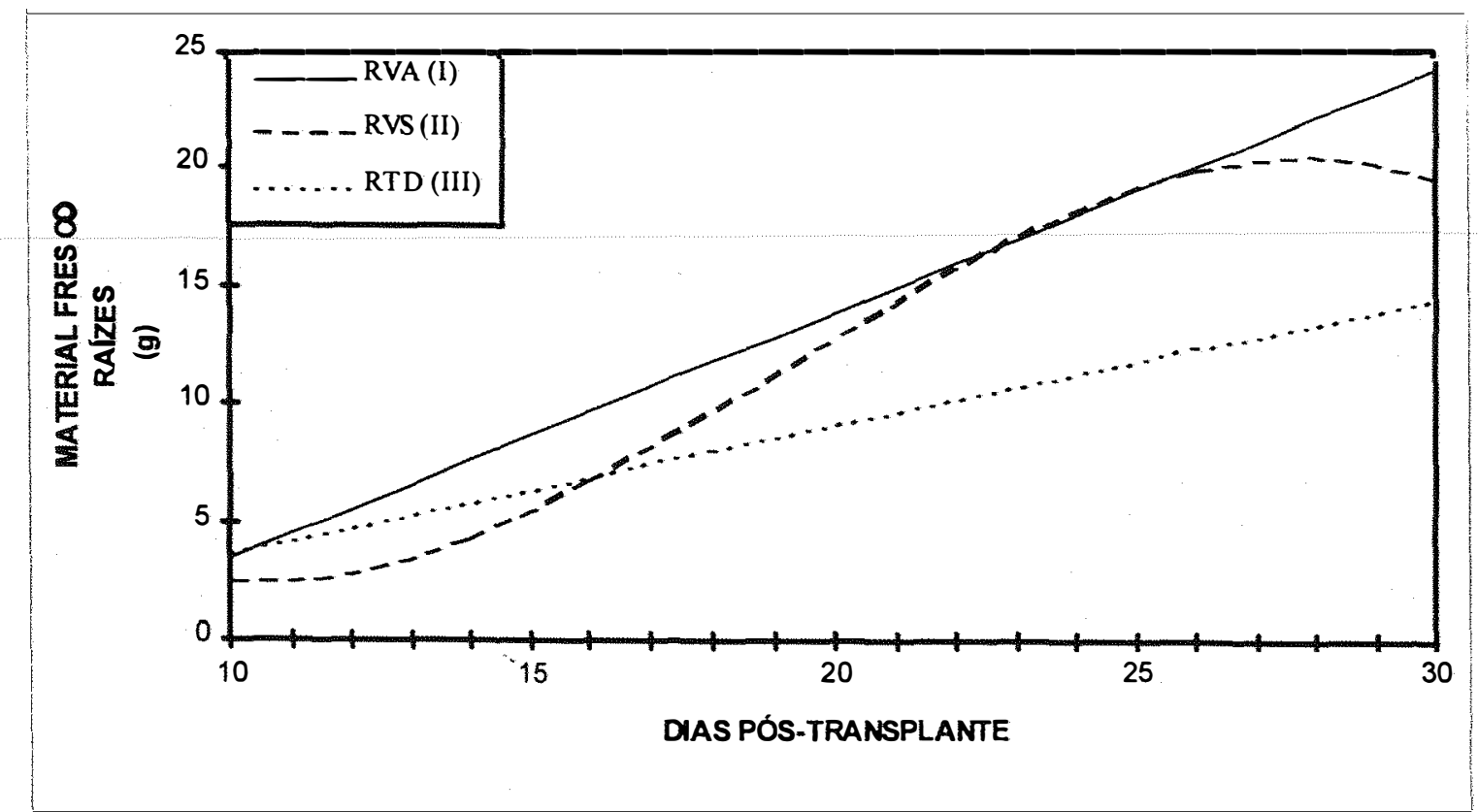

A
(I) $\mathrm{y}=-7,0124+1,046 \mathrm{x} \quad \mathrm{R}^{2}=0,948$
(II) $y=30,8598-6,1638143 \mathrm{x}+0,40288286 \mathrm{x}^{2}-0,006992 \mathrm{x}^{3} \quad \mathrm{R}^{2}=0,999$
(III) $y=-1,9406+0,56288 x-0,000468 x^{3} \quad R^{2}=0,968$

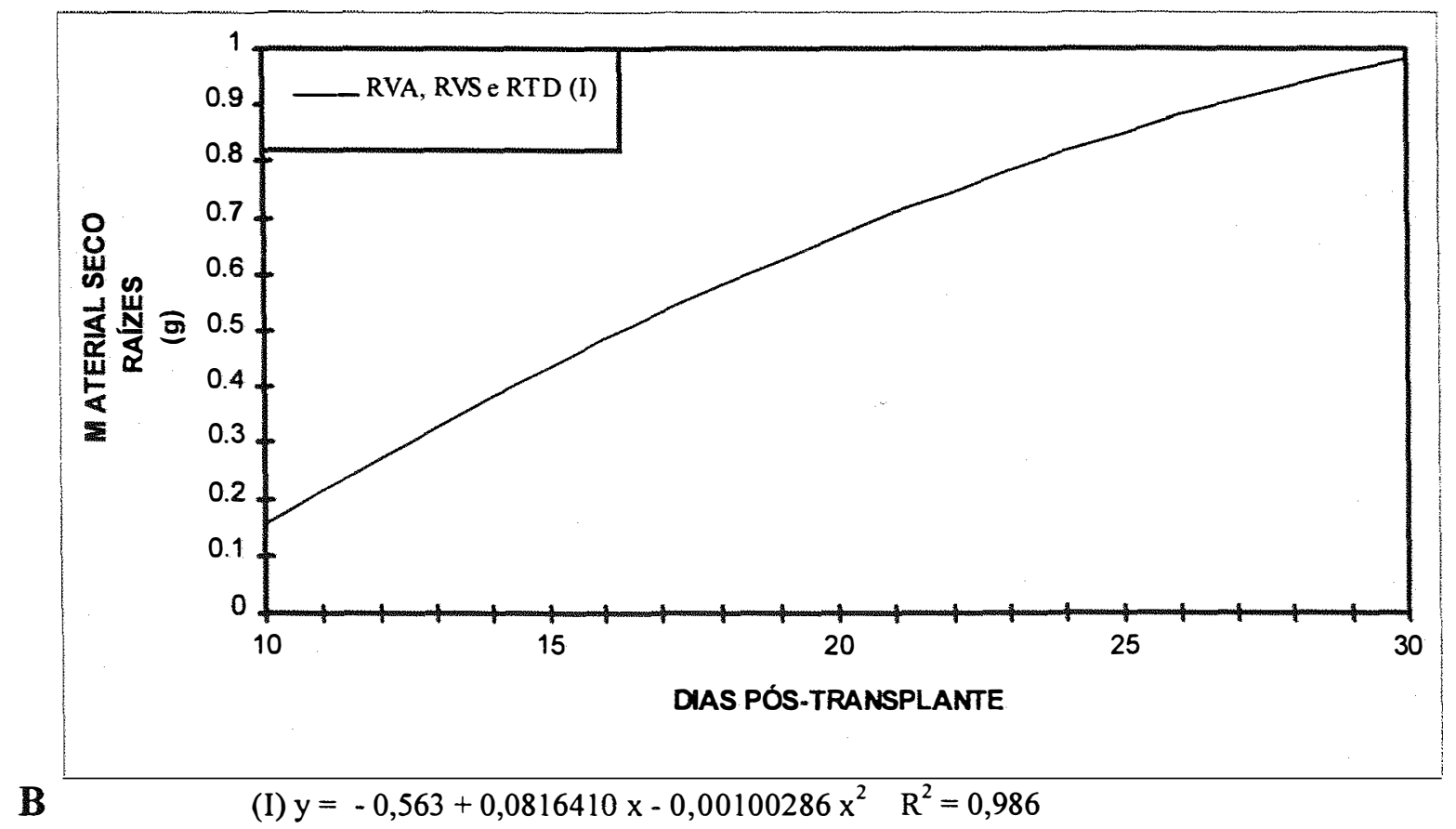

Figura 18. Comportamento da produção de material fresco e material seco do sistema radicular da alface cultivar Verônica, em "NFT", sob três formas de manejo da solução nutritiva, no período do transplante até a colheita. 


\subsubsection{Parte Aérea}

As produções e o comportamento do acúmulo de MF e MS da parte aérea da alface, constam na tabela 5 e figura 19. Não foi detectado efeito significativo da interação entre épocas de coleta e tratamentos sobre a produção de MF da parte aérea mas, considerando-se os resultados obtidos para tratamentos detectou-se diferença significativa entre eles (Anexo B3). A produção de MF da parte aérea foi maior na RTD, que não diferiu significativamente da obtida na RVS. As produções na RVS e na RVA também não diferiram entre si, porém houve diferença significativa entre a produção na RTD e na RVA. Os resultados estatísticos obtidos para a produção de MS da parte aérea foram iguais a esses (Anexo B3).

Faquin et al. (1996) obtiveram valores maiores para a produção de MF e MS da parte aérea de alface que os obtidos neste experimento porém isso pode atribuir-se ao fato de que esses autores cultivaram duas plantas por furo enquanto que neste trabalho foi cultivada uma só.

Tabela 5 - Produção de material fresco e material seco da parte aérea da alface cultivar Verônica, em "NFT", em cinco épocas de amostragem.

\begin{tabular}{cccccc}
\hline & \multicolumn{5}{c}{ DIAS POS-TRANSPLANTE } \\
\cline { 2 - 6 } MF (g) & $\mathbf{1 0}$ & $\mathbf{1 5}$ & $\mathbf{2 0}$ & $\mathbf{2 5}$ & $\mathbf{3 0}$ \\
\hline RTD & 15,851 & 37,98 & 82,96 & 154,95 & 216,02 \\
RVS & 15,051 & 27,74 & 54,18 & 153,06 & 196,30 \\
RVA & 14,232 & 34,75 & 68,70 & 117,56 & 183,93 \\
\hline MS (g) & & & & & \\
\hline RTD & 0,87 & 2,19 & 4,97 & 6,80 & 9,03 \\
RVS & 0,90 & 1,91 & 3,55 & 6,54 & 8,38 \\
RVA & 0,83 & 2,02 & 3,94 & 5,01 & 7,35 \\
\hline
\end{tabular}

${ }^{\mathrm{TS}} \Rightarrow$ Interação não significativa entre tratamentos e épocas pelo teste $\mathrm{F}(\alpha=0,05)$. 


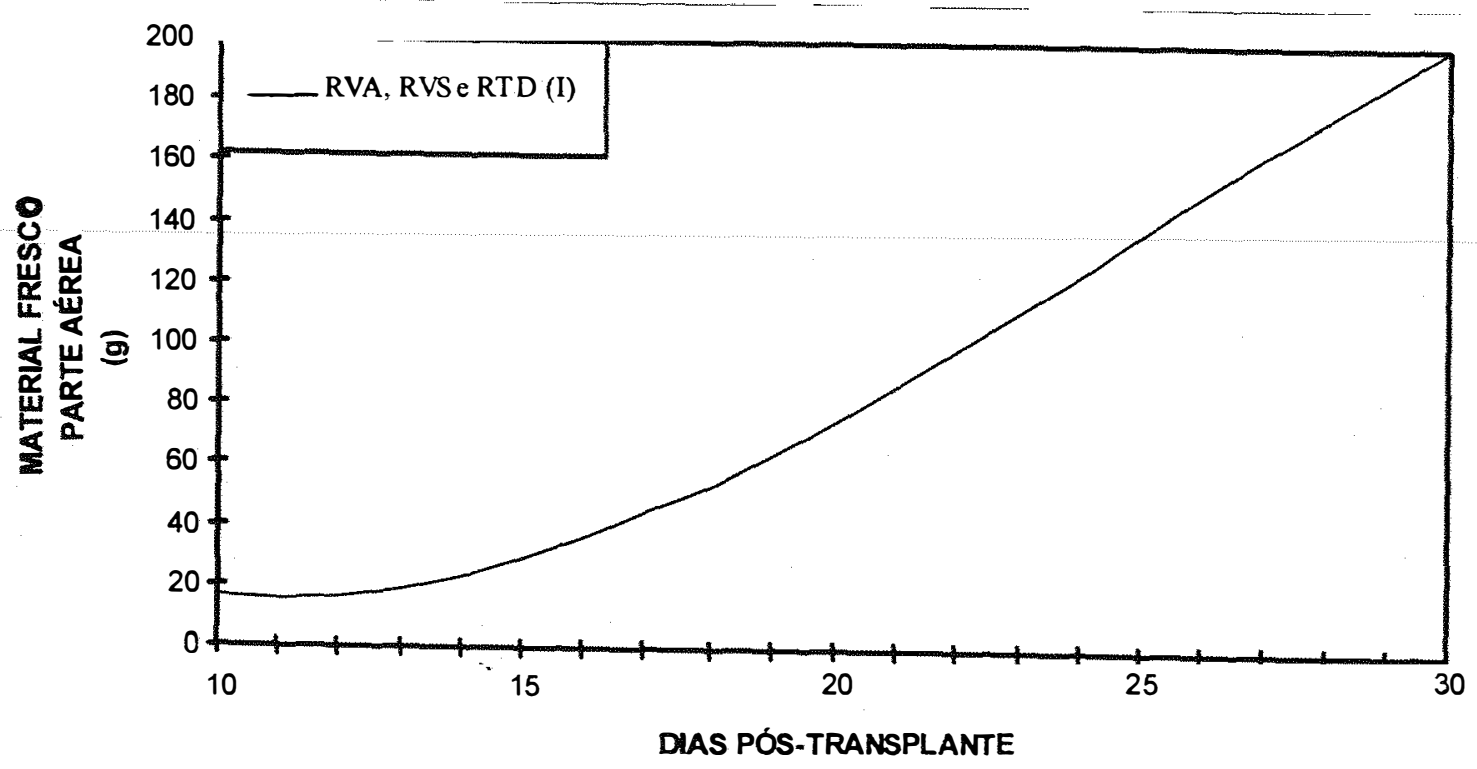

A

(I) $y=154,911266-28,169376 x+1,6492219 x^{2}-0,022010667 x^{3} \quad R^{2}=0,996$

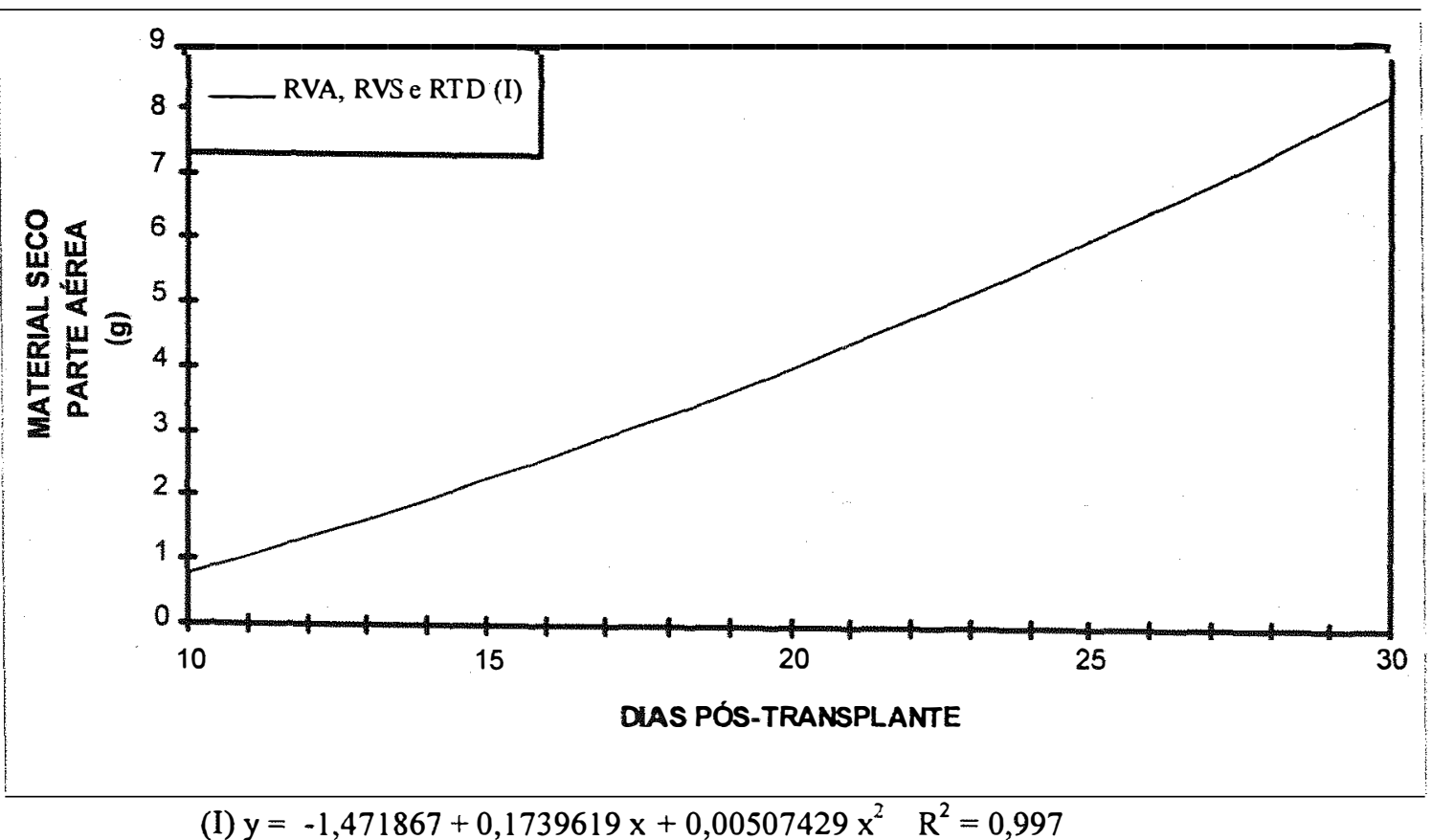

Figura 19. Comportamento da produção de material fresco e material seco da parte aérea da alface cultivar Verônica, em "NFT", média das três formas de manejo da solução nutritiva, no período do transplante até a colheita. 
A produção de MF foi mais lenta dos 10-15 dpt acelerando dos $15 \mathrm{dpt}$ até a colheita (Figura 19 A), para todos os tratamentos. A produção de MS cresceu linearmente durante o ciclo da alface, para os três tratamentos estudados.

A percentagem de MS na RVA foi 5,$88 ; 5,81 ; 5,73 ; 4,26$ e 3,99 \%; na RVS foi 5,52; 5,78; 5,99; 4,39 e 4,18 \% e na RTD foi 5,99; 6,90; 6,56; 4,27 e 4,27 $\%$, respectivamente, nas amostragens. O comportamento da percentagem de MS da parte aérea foi semelhante ao observado nas raízes, podendo-se atribuí-lo às mesmas causas.

\subsubsection{Planta Inteira}

$\mathrm{Na}$ figura 20 pode-se observar o desenvolvimento da alface no transplante e nas épocas de amostragem.

Para a produção de MF e MS da planta inteira de alface não foi observada interação entre épocas e tratamentos (Tabela 6). Não foi observada diferença significativa para MF entre tratamentos (Anexo B3). Para MS somente houve diferença significativa entre a RTD que teve o maior valor e a RVA que teve o menor valor(Anexo B3).

Tabela 6. Produção de material fresco e de material seco da planta inteira de alface cultivar Verônica, em "NFT", em cinco épocas de amostragem.

\begin{tabular}{cccccc}
\hline & \multicolumn{5}{c}{ DIAS POS-TRANSPLANTE } \\
\cline { 2 - 7 } MF (g) & $\mathbf{1 0}$ & $\mathbf{1 5}$ & $\mathbf{2 0}$ & $\mathbf{2 5}$ & $\mathbf{3 0}$ \\
\hline RTD & 18,87 & 44,56 & 93,42 & 162,73 & 230,44 \\
RVS & 17,61 & 33,02 & 67,25 & 172,20 & 216,10 \\
RVA & 16,47 & 43,21 & 86,00 & 135,24 & 207,80 \\
\hline MS (g) & & & & & \\
\hline RTD & 1,03 & 2,57 & 5,59 & 7,45 & 9,93 \\
RVS & 1,05 & 2,28 & 4,27 & 4,27 & 9,42 \\
RVA & 0,98 & 2,51 & 4,73 & 4,73 & 8,40 \\
\hline
\end{tabular}

$\Rightarrow$ Interação não significativa entre tratamentos e épocas pelo teste $F(\alpha=0,05)$. 

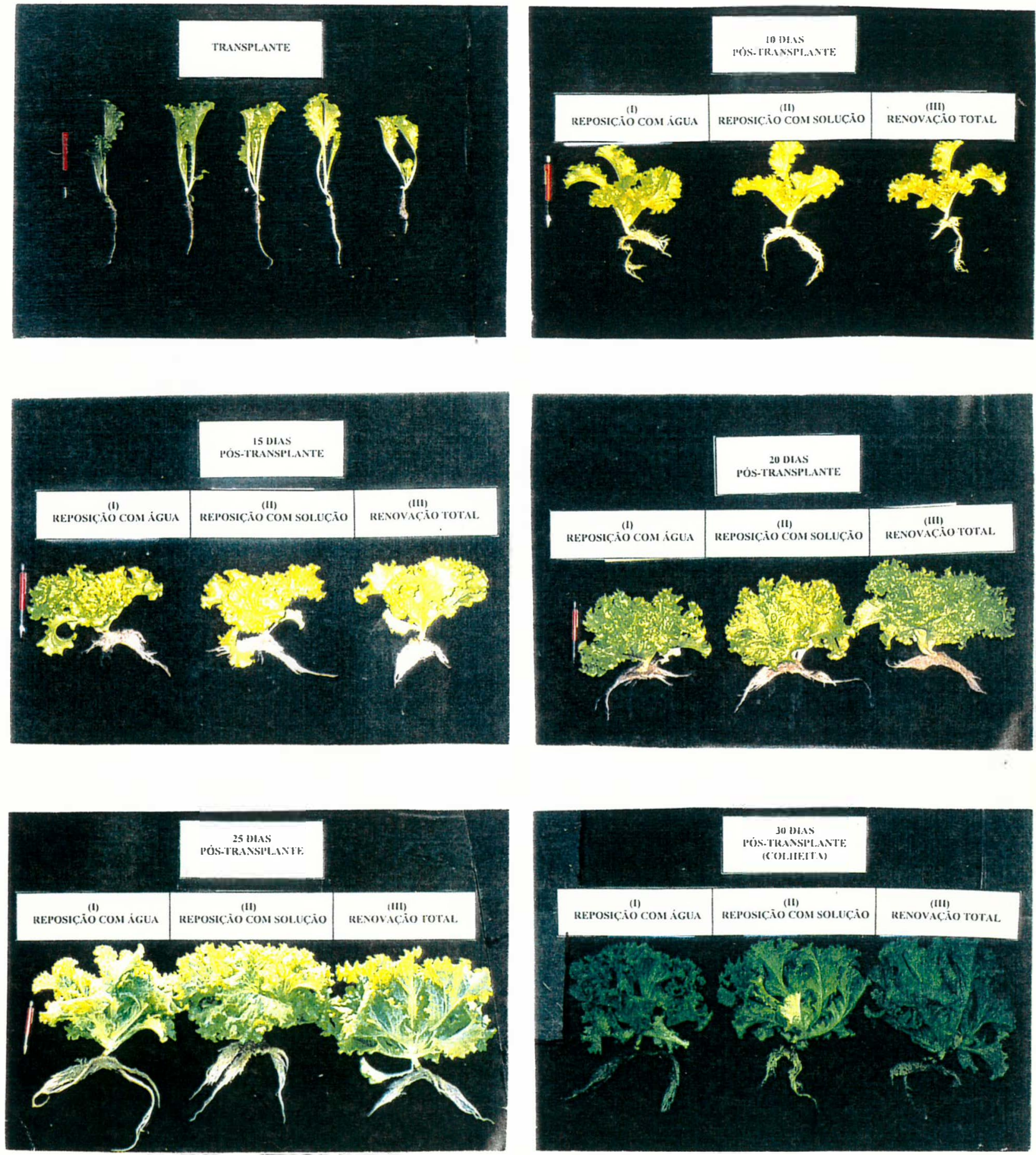

Figura 20. Desenvolvimento da alface cultivar Verônica no transplante e nas épocas de amostragem. 


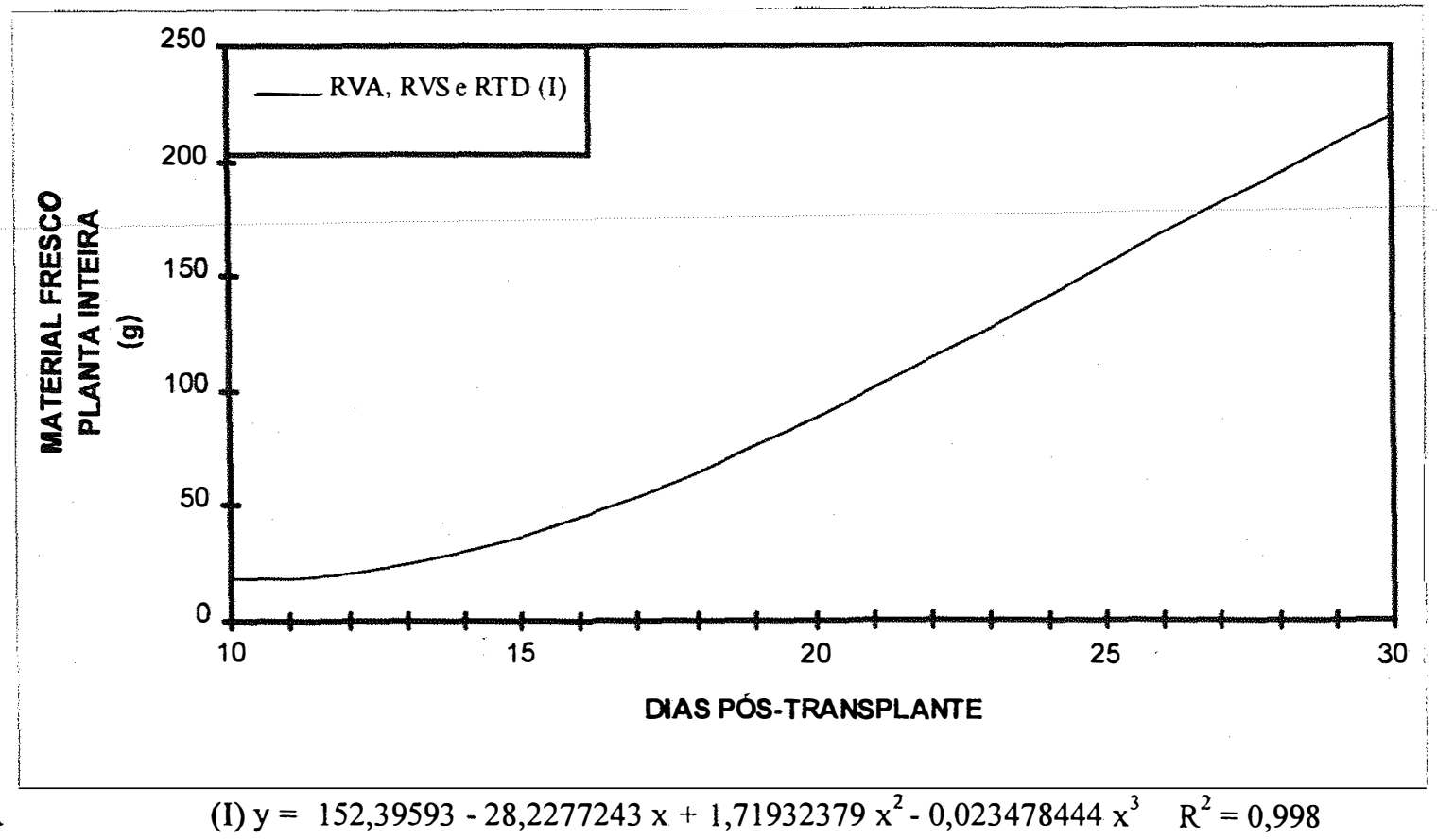

A

(I) $y=152,39593-28,2277243 x+1,71932379 x^{2}-0,023478444 x^{3} \quad R^{2}=0,998$

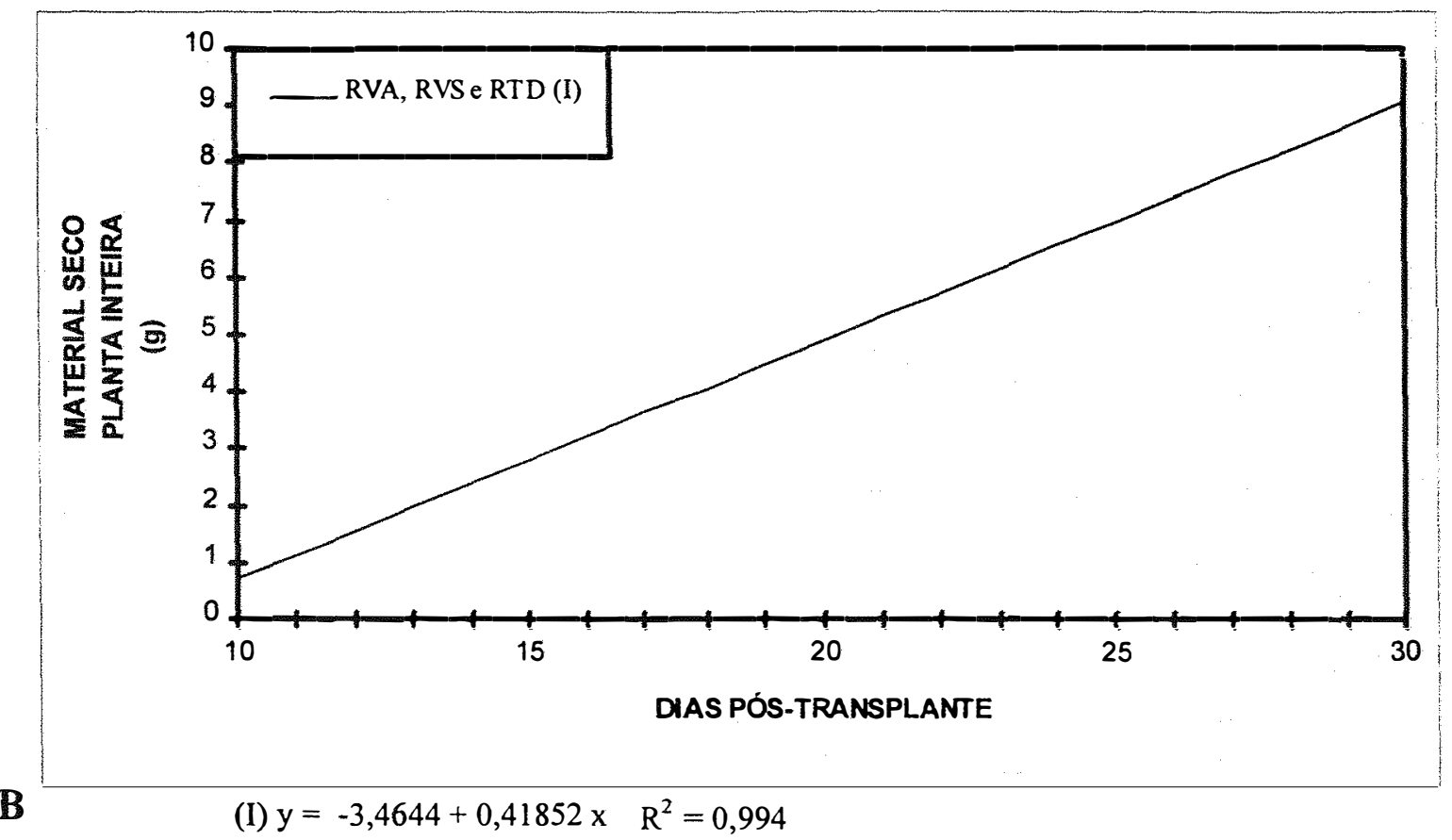

Figura 20. Comportamento da produção de material fresco e material seco da planta inteira de alface cultivar Verônica, em "NFT", média das três formas de manejo da solução nutritiva, no período do transplante até a colheita. 
Quanto ao comportamento do MF no período (Figura $21 \mathrm{~A}$ ), ocorreu um incremento lento dos 10-15 dpt e depois um aumento linear progressivo até a colheita, seguindo o mesmo comportamento obtido para parte aérea. Isso demonstra que a parte aérea impôs seu comportamento a planta inteira, uma vez que ela é responsável pela maior fração do MF da alface.

O MS teve um aumento linear do transplante à colheita (Figura $21 \mathrm{~B}$ ), também seguindo o mesmo comportamento obtido para parte aérea. As percentagens de MS da planta inteira, nos períodos amostrados foram as seguintes para a RVA: 5,$99 ; 5,81 ; 5,50 ; 3,49$ e $4,04 \%$. Sendo 5,$98 ; 6,91 ; 6,35 ; 2,48 ; 4,36 \%$ para a RVS e 5,$50 ; 5,78 ; 5,98 ; 4,58$ e 4,31\% para a RTD, respectivamente, nessas mesmas épocas. Como os comportamentos dessa variável foram semelhantes para raízes e parte aérea, não diferiram também para a planta inteira.

A relação $\mathrm{MF}$ do sistema radicular/MF da parte aérea, nas cinco épocas amostradas, comportou-se da seguinte forma para RVA $(0,16 ; 0,24 ; 0,25 ; 0,15$; $0,13), \operatorname{RVS}(0,17 ; 0,19 ; 0,24 ; 0,12 ; 0,10)$ e RTD $(0,19 ; 0,17 ; 0,13 ; 0,07 ; 0,06)$.

A RVA e a RVS tiveram um aumento nos valores dessa relação, dos 10 aos $20 \mathrm{dpt}$, voltando a reduzir até a colheita. Para a RDT o maior valor foi observado no início $(10 \mathrm{dpt})$ diminuindo em direção à colheita. Nesse tratamento esses valores foram sempre menores, com exceção dos $10 \mathrm{dpt}$, sendo que essa diferença em relação aos demais tratamentos, tornou-se cada vez maior até a colheita.

Na RTD, a troca diária da solução, portanto com proporções de nutrientes mais favoráveis à absorção, além da eliminação das substâncias tóxicas, que se acumulariam na solução, possibilitou um desenvolvimento menor do sistema radicular e maior da parte aérea causando uma relação mais favorável ao aumento da transpiração (Biaglogwski, 1936), possibilitando um maior desenvolvimento 
da cabeça, o que é desejado, por se tratar da parte desse vegetal que é consumida pelo ser humano.

Steiner (1980) afirmou que proporções de nutrientes na solução muito aquém ou além das proporções com que são absorvidas pelas plantas, causam um gasto extra de energia nas raízes, para absorver esses nutrientes nas proporções adequadas as suas necessidades e isso seria o que aconteceu na RVA e na RVS. Em situações em que essa relação é mantida mais favorável, como no caso da RTD, essa energia é economizada e pode ser utilizada em outras partes da planta como por exemplo, na produção de folhas.

\subsubsection{Concentração e absorção de nutrientes}

\subsubsection{Nitrogênio}

Os resultados obtidos para as concentrações de nitrogênio na planta não apresentaram interação entre épocas e tratamentos (Tabela 7). Na análise dos tratamentos, a RTD apresentou as maiores concentrações e diferiu significativamente dos demais tratamentos, que não diferiram significativamente entre si (Anexo B3).

Dos tratamentos estudados a RTD foi que apresentou valor de concentração de nitrogênio mais próximo ao valor encontrado por Faquin et al. (1996) para a cultivar de alface Verônica no $30^{\circ} \mathrm{dpt}$.

Para a quantidade de nitrogênio absorvida não houve diferença significativa até os $15 \mathrm{dpt}$ (Tabela 7). Nos $20 \mathrm{dpt}$, a RTD diferenciou-se significativamente dos demais tratamentos. Aos $25 \mathrm{dpt}$, a quantidade de nitrogênio absorvida pela alface na RVS não diferiu significativamente da RTD sugerindo uma recuperação das plantas como conseqüência da troca da solução 
(23 dpt). A RTD e a RVS apresentaram quantidades de nitrogênio absorvidas pela alface com valores mais próximos aos encontrados por Faquin et al. (1996) para a mesma cultivar de alface, no $30^{\circ} \mathrm{dpt}$.

Tabela 7 - Concentrações de nitrogênio no material seco e quantidades absorvidas pela alface cultivar Verônica, em "NFT", em cinco épocas de amostragem.

\begin{tabular}{|c|c|c|c|c|c|}
\hline \multirow[b]{2}{*}{ CONCENTRAÇÃO $\left(\mathrm{g} \mathrm{kg}^{-1}\right)^{\mathrm{NS}}$} & \multicolumn{5}{|c|}{ DIAS POS-TRANSPLANTE } \\
\hline & 10 & 15 & 20 & 25 & 30 \\
\hline RTD & 48,00 & 47,33 & 44,83 & 46,38 & 43,46 \\
\hline RVS & 47,23 & 40,41 & 37,42 & 41,90 & 37,88 \\
\hline RVA & 45,81 & 38,75 & 38,35 & 41,30 & 36,36 \\
\hline \multicolumn{6}{|c|}{ QTDADE. ABSORVIDA (mg planta ${ }^{-1}$ ) } \\
\hline RTD & $49,7 \mathrm{a}$ & $121,4 \mathrm{a}$ & $251,9 a$ & $345,7 \mathrm{a}$ & $432,8 \mathrm{a}$ \\
\hline RVS & $51,5 \mathrm{a}$ & $97,2 \mathrm{a}$ & 159,7 b & $312,6 \mathrm{a}$ & $356,7 \mathrm{~b}$ \\
\hline RVA & $45,3 \mathrm{a}$ & 92,7 a & $180,9 \mathrm{~b}$ & 244,6 b & $308,3 \mathrm{~b}$ \\
\hline \multicolumn{6}{|l|}{$\overline{\mathrm{DMS}}=64,9$} \\
\hline \multicolumn{6}{|c|}{$\begin{array}{l}* \text { Interação não significativa entre tratamentos e épocas pelo teste } \mathrm{F}(\alpha=0,05) . \\
\Rightarrow \text { Interação significativa entre tratamentos e épocas pelo teste } \mathrm{F}(\alpha=0,05) .\end{array}$} \\
\hline
\end{tabular}

$\mathrm{Na}$ colheita, a quantidade de nitrogênio absorvida foi maior na RTD diferindo significativamente dos demais tratamentos (Tabela 7). Isso pode-se atribuir à maior concentração desse elemento no MS e à maior produção de MS nesse tratamento, principalmente em relação à RVA. A RVA e a RVS não diferiram significativamente entre si, uma vez que a concentração de nitrogênio no MS e a produção de MS foram semelhantes nesses tratamentos.

Quanto à marcha de absorção para a RVA e RTD (Figura 22), o nirrogênio teve um incremento linear, sendo mais rápido e maior na RTD. Na RVS , houve uma estabilidade dos 10-12 dpt, aumentando linearmente até os 25 dpt e continuando a aumentar até a colheita, porém mais lentamente. 


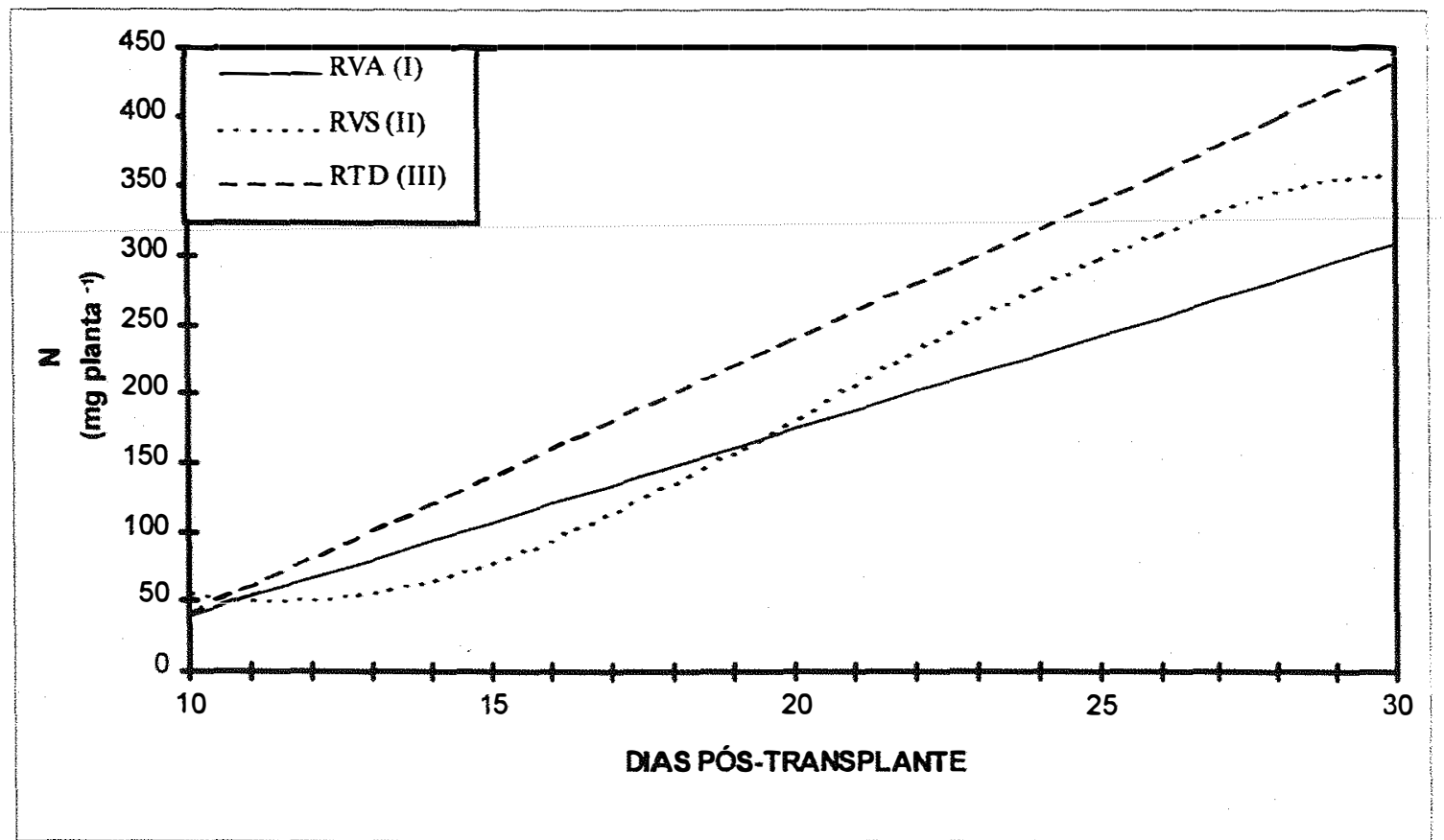

(I) $\mathrm{y}=-94,687+13,4686 \mathrm{x} \quad \mathrm{R}^{2}=0,994$

(II) $y=519,856-93,9897 x+5,64961 x^{2}-0,089795 x^{3} \quad R^{2}=0,987$

(III) $\mathrm{y}=-155,899+19,8113 \times \quad \mathrm{R}^{2}=0,993$

Figura 22. Marcha de absorção do nitrogênio para alface cultivar Verônica, em "NFT", sob três formas de manejo da solução nutritiva, no período do transplante até a colheita.

\subsubsection{Fósforo}

A concentração de fósforo foi maior na RTD, diferindo significativamente dos demais tratamentos aos 10, 15 e 30 dpt. Na RVA não diferiu significativamente da RVS até os $15 \mathrm{dpt}$, mas diferiu dos demais tratamentos aos 20, 25 e $30 \mathrm{dpt}$ (Tabela 8).

Quanto à comparação dos valores da concentração de fósforo obtidos no $30^{\circ} \mathrm{dpt}$ nos tratamentos estudados em relação ao obtido por Faquin et al. (1996), a RVA atingiu o valor mais próximo, para a mesma cultivar de alface em "NFT". 
Tabela 8 - Concentrações de fósforo no material seco e quantidades absorvidas pela alface cultivar Verônica, em "NFT", em cinco épocas de amostragem.

\begin{tabular}{|c|c|c|c|c|c|}
\hline \multirow[b]{2}{*}{$\operatorname{CONCENTRAÇÃO}\left(\mathrm{g} \mathrm{kg}^{-1}\right)^{\star *}$} & \multicolumn{5}{|c|}{ DIAS POS-TRANSPLANTE } \\
\hline & 10 & 15 & 20 & 25 & 30 \\
\hline RTD & $10,47 \mathrm{a}$ & $7,23 \mathrm{a}$ & $7,23 \mathrm{a}$ & $8,62 \mathrm{a}$ & $9,52 \mathrm{a}$ \\
\hline RVS & $8,12 \mathrm{~b}$ & $5,17 \mathrm{~b}$ & $6,58 \mathrm{a}$ & $9,41 \mathrm{a}$ & $8,47 \mathrm{~b}$ \\
\hline RVA & $7,31 \mathrm{~b}$ & $5,12 \mathrm{~b}$ & $4,67 \mathrm{~b}$ & $6,74 \mathrm{~b}$ & $7,33 \mathrm{c}$ \\
\hline \multicolumn{6}{|l|}{$\mathrm{DMS}=1,11$} \\
\hline \multicolumn{6}{|c|}{ QTDADE. ABSORVIDA (mg planta ${ }^{-1}$ ) } \\
\hline RTD & $10,8 \mathrm{a}$ & $18,4 \mathrm{a}$ & $39,7 \mathrm{a}$ & $64,8 \mathrm{a}$ & $95,1 \mathrm{a}$ \\
\hline RVS & $8,6 \mathrm{a}$ & $11,8 \mathrm{a}$ & $28,0 \mathrm{ab}$ & $69,6 \mathrm{a}$ & $78,9 \mathrm{~b}$ \\
\hline RVA & $7,2 \mathrm{a}$ & $12,7 \mathrm{a}$ & $21,9 \mathrm{~b}$ & $39,5 \mathrm{~b}$ & $63,8 \quad \mathrm{c}$ \\
\hline
\end{tabular}

$\Rightarrow$ Interação significativa entre tratamentos e épocas pelo teste $F(\alpha=0,05)$.

Médias seguidas pela mesma letra em cada sub-coluna de época, não diferem entre si pelo teste de Tukey $(\alpha=0,05)$.

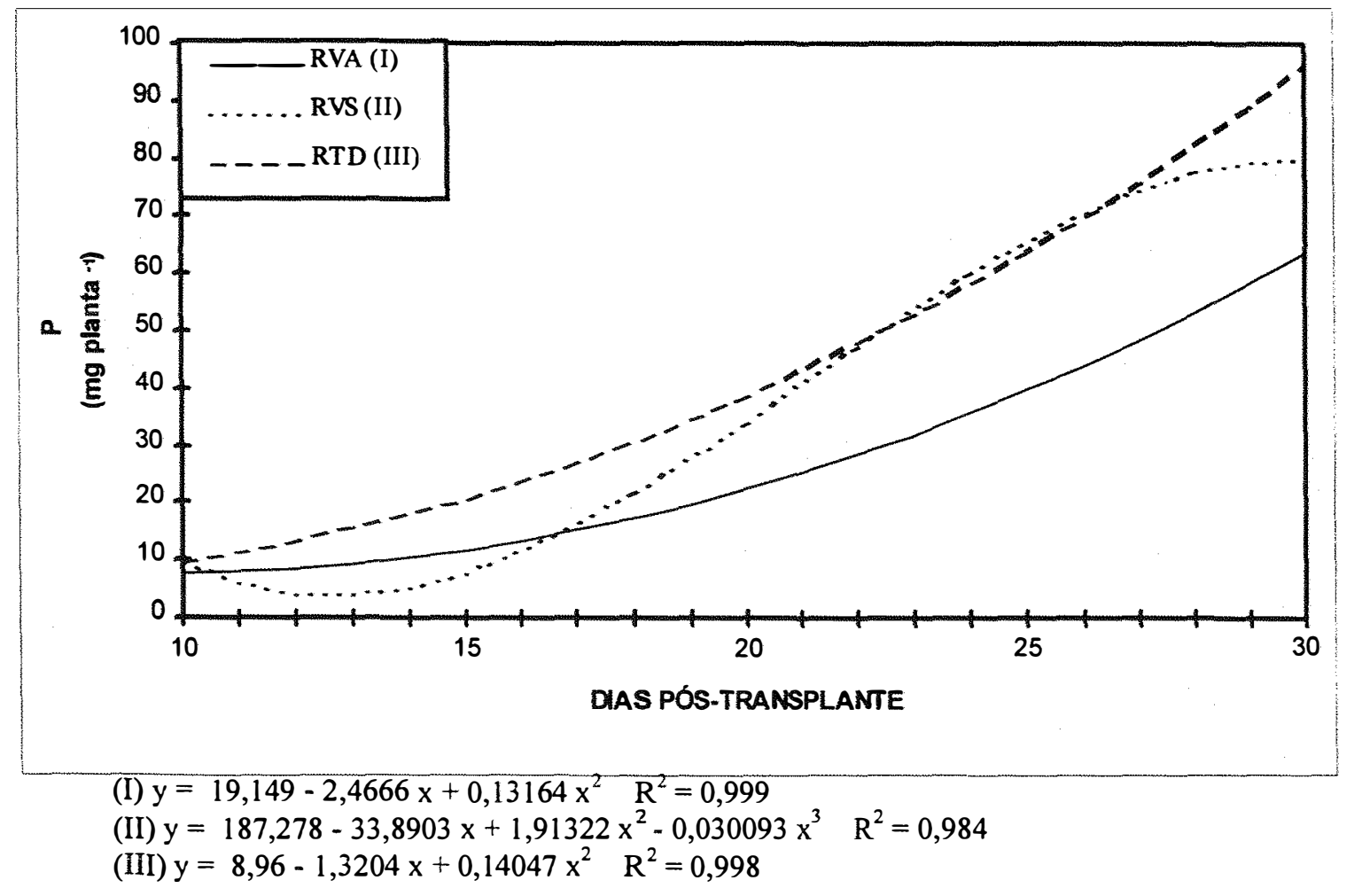

Figura 23. Marcha de absorção do fósforo para a alface cultivar Verônica, em "NFT", sob três formas de manejo da solução nutritiva, no período do transplante até a colheita. 
A quantidade de fósforo absorvida não apresentou diferença significativa até os $15 \mathrm{dpt}$ entre os tratamentos (Tabela 8). A partir dos $15 \mathrm{dpt}$ a RTD diferiu sempre significativamente da RVA, que apresentou as menores quantidades de fósforo absorvidas. A RVS não diferiu estatisticamente dos demais tratamentos até os $20 \mathrm{dpt}$, aos $25 \mathrm{dpt}$ somente diferiu da RVA e na colheita diferiu das outras formas de manejo da solução. No $30^{\circ} \mathrm{dpt}$ a RVA e a RVS apresentaram quantidades de fósforo absorvidas com valores próximos aos encontrados por Faquin et al. (1996).

Também para o fósforo, a RVA e a RTD tiveram uma marcha de absorção semelhante e em forma de curva quadrática, porém na RTD a absorção foi mais rápida durante o ciclo e portanto maior na colheita (Figura 23). A marcha de absorção na RVS representou uma curva cúbica sendo que praticamente até os 15 dias se manteve estável, passando por uma fase de rápida absorção próximo á colheita quando voltou a estabilizar-se.

\subsubsection{Potássio}

A concentração de potássio foi maior até o $10^{0}$ dpt na RTD que nos demais tratamentos, passando a ser maior na RVA, aos 20 e 25 dpt e na RVS nos 25 e 30 dpt. A RVA e a RVS não diferiram entre si aos 10, 20 e 30 dpt (Tabela 9). $\mathrm{Na}$ colheita, na RTD foi menor e diferiu significativamente dos demais tratamentos. Aos $30 \mathrm{dpt}$ todos os tratamentos apresentaram valores de concentração de potássio maiores que os observados por Faquin et al. (1996), sendo que, a RVA apresentou valor mais próximo ao encontrado por esses autores.

A quantidade absorvida de potássio não diferiu significativamente até os 20 e aos $30 \mathrm{dpt}$ entre os tratamentos (Tabela 9). Aos $25 \mathrm{dpt}$ somente a RVA 
diferiu da RVS. Na colheita a quantidade de potássio absorvida não diferiu significativamente entre os tratamentos porque a menor concentração de potássio no MS da RTD foi compensada pelo sua maior produção de MS em relação aos demais tratamentos. As quantidades de potássio absorvidas até os $30 \mathrm{dpt}$ em todos os tratamentos foram maiores que as quantidades encontradas por Faquin et al. (1996) em plantas de alface da mesma cultivar e idade.

Tabela 9 - Concentrações de potássio no material seco e quantidades absorvidas pela alface cultivar Verônica, em "NFT", em cinco épocas de amostragem.

\begin{tabular}{cccccccc}
\hline & \multicolumn{6}{c}{ DIAS PÓS-TRANSPLANTE } \\
\cline { 2 - 7 } CONCENTRAÇÃO $\left(\mathrm{g} \mathrm{kg}^{-1}\right)^{* *}$ & $\mathbf{1 0}$ & $\mathbf{1 5}$ & $\mathbf{2 0}$ & $\mathbf{2 5}$ & $\mathbf{3 0}$ \\
\hline RTD & $70,84 \mathrm{a}$ & $61,51 \mathrm{a}$ & 56,62 & $\mathrm{~b}$ & 67,17 & $\mathrm{~b}$ & $61,97 \mathrm{~b}$ \\
RVS & 61,05 & $\mathrm{~b}$ & 52,48 & $\mathrm{~b}$ & $66,32 \mathrm{ab}$ & $76,83 \mathrm{a}$ & $70,99 \mathrm{a}$ \\
RVA & 60,90 & $\mathrm{~b}$ & $67,48 \mathrm{a}$ & $62,73 \mathrm{a}$ & 69,31 & $\mathrm{~b}$ & $71,14 \mathrm{a}$ \\
\hline
\end{tabular}

DMS $=7,63$

QTDADE. ABSORVIDA (mg planta $^{-1}$ )

\begin{tabular}{lllllll}
\hline & RTD & $73,8 \mathrm{a}$ & $159,2 \mathrm{a}$ & $322,8 \mathrm{a}$ & $506,5 \mathrm{ab}$ & $615,4 \mathrm{a}$ \\
& RVS & $64,4 \mathrm{a}$ & $120,1 \mathrm{a}$ & $282,1 \mathrm{a}$ & $572,2 \mathrm{a}$ & $670,8 \mathrm{a}$ \\
& RVA & $60,1 \mathrm{a}$ & $169,6 \mathrm{a}$ & $377,8 \mathrm{a}$ & $406,2 \mathrm{~b}$ & $600,4 \mathrm{a}$ \\
\hline
\end{tabular}

$\Rightarrow$ Interação significativa entre tratamentos e épocas pelo teste $F(\alpha=0,05)$.

Médias seguidas da mesma letra em cada sub-coluna de época, não diferem entre si pelo teste de Tukey $(\alpha=0,05)$.

Quanto à marcha de absorção a RVA e a RTD apresentaram um comportamento linear e progressivo sendo que foi um pouco mais rápido na RTD dos 15 dpt até a colheita (Figura 24). Na RVS a absorção foi quase que estável até os $15 \mathrm{dpt}$, aumentando depois até os $25 \mathrm{dpt}$ e continuou a aumentar até a colheita, mas em ritmo menor. 


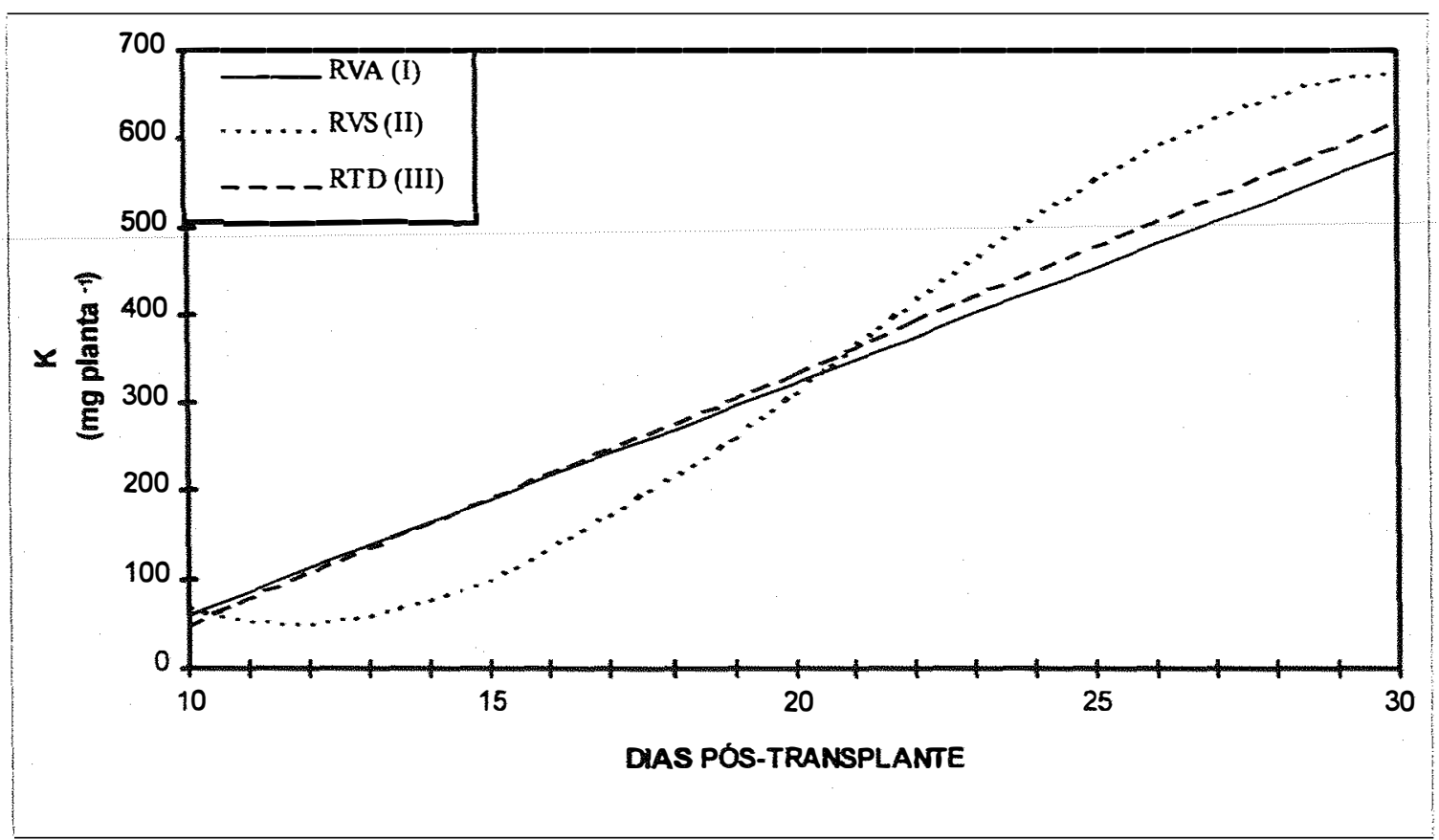

(I) $y=-204,36+26,3426 x \quad R^{2}=0,966$

(II) $y=1.140,651-212,5086 x+12,52249 x^{2}-0,198518 x^{3} \quad R^{2}=0,994$

(III) $y=-236,723+28,6138 x \quad R^{2}=0,987$

Figura 24. Marcha de absorção do potássio para a alface cultivar Verônica, em "NFT", sob três formas de manejo da solução nutritiva, no período do transplante até a colheita.

\subsubsection{Cálcio}

A RVA e a RVS não diferiram estatisticamente entre si quanto a concentração de cálcio em todos os períodos de amostragem (Tabela 10). Não houve diferença significativa entre os tratamentos nos 15 e $20 \mathrm{dpt}$. Aos $25 \mathrm{dpt}$ a concentração foi mais menor na RTD do que nos demais tratamentos. Na colheita, a concentração de cálcio no MS da alface na RTD somente diferiu significativamente da RVS, que não diferiu da RVA.

Os valores de concentrações de cálcio encontrados nos tratamentos estão muito abaixo dos encontrados por Faquin et al. (1996). Isso sugere que a concentração de cálcio na solução inicial é insuficiente para garantir o suprimento 
desse elemento durante o ciclo todo da alface e que a concentração desse elemento deveria ser aumentada na formulação da solução e/ou que a proporção de potássio na formulação deveria ser diminuída em relação ao cálcio para evitar efeito de sinergismo daquele elemento em relação a este, no processo de absorção.

Tabela 10 - Concentrações de cálcio no material seco e quantidades absorvidas pela alface cultivar Verônica, em "NFT", em cinco épocas de amostragem.

\begin{tabular}{|c|c|c|c|c|c|}
\hline \multirow[b]{2}{*}{ CONCENTRAÇÃO $\left(\mathrm{g} \mathrm{kg}^{-1}\right)^{* \star}$} & \multicolumn{5}{|c|}{ DIAS PÓS-TRANSPLANTE } \\
\hline & 10 & 15 & 20 & 25 & 30 \\
\hline RTD & $9,90 \mathrm{a}$ & $6,68 \mathrm{a}$ & $7,15 \mathrm{a}$ & $8,03 \quad b$ & $9,34 \quad b$ \\
\hline RVS & $7,91 \quad b$ & $6,75 \mathrm{a}$ & $7,66 \mathrm{a}$ & $10,56 \mathrm{a}$ & $10,70 \mathrm{a}$ \\
\hline RVA & $8,34 \mathrm{~b}$ & $7,45 \mathrm{a}$ & $8,39 \mathrm{a}$ & $10,17 \mathrm{a}$ & $10,02 \mathrm{ab}$ \\
\hline \multicolumn{6}{|l|}{$\mathrm{DMS}=1,35$} \\
\hline \multicolumn{6}{|c|}{ QTDADE. ABSORVIDA (mg planta ${ }^{-1}$ ) } \\
\hline RTD & $10,3 \mathrm{a}$ & $17,3 \mathrm{a}$ & $40,3 \mathrm{a}$ & $51,2 b$ & $92,4 \mathrm{a}$ \\
\hline RVS & $8,3 \mathrm{a}$ & $15,4 \mathrm{a}$ & 39,5 a & 80,3 a & $97,8 \mathrm{a}$ \\
\hline RVA & $8,3 \mathrm{a}$ & $18,4 \mathrm{a}$ & $32,7 \mathrm{a}$ & $60,3 \mathrm{~b}$ & $84,0 \mathrm{a}$ \\
\hline
\end{tabular}

$\Rightarrow$ Interação significativa entre tratamentos e épocas pelo teste $F(\alpha=0,05)$.

Médias seguidas da mesma letra em cada sub-coluna de época, não diferem entre si pelo teste de Tukey $(\alpha=0,05)$.

Para a quantidade de cálcio absorvida não ocorreu diferença significativa nos $10,15,20$ e $30 \mathrm{dpt}$ entre os tratamentos (Tabela 10). Aos $25 \mathrm{dpt}$ a quantidade absorvida foi maior na RVS que nos demais tratamentos. Na colheita, para a quantidade de cálcio absorvida não foi observada diferença significativa entre os tratamentos porque a maior produção de MS da alface na RTD compensou a menor concentração desse elemento no MS. As quantidades de cálcio absorvidas pelas plantas de alface até o $30^{\circ} \mathrm{dpt}$, em todos os tratamentos foram inferiores aos valores obtidos por Faquin et al. (1996) para plantas da cultivar Verônica da mesma idade. 
A marcha de absorção do cálcio teve comportamento linear crescente na RVA (Figura 25). Na RTD apresentou um comportamento quadrático, em que até os 15 dpt a absorção foi lenta, passando a aumentar rapidamente até a colheita. $\mathrm{Na}$ RVS o comportamento foi em forma de curva cúbica ficando praticamente estável até os $15 \mathrm{dpt}$, aumentando rapidamente até à colheita.

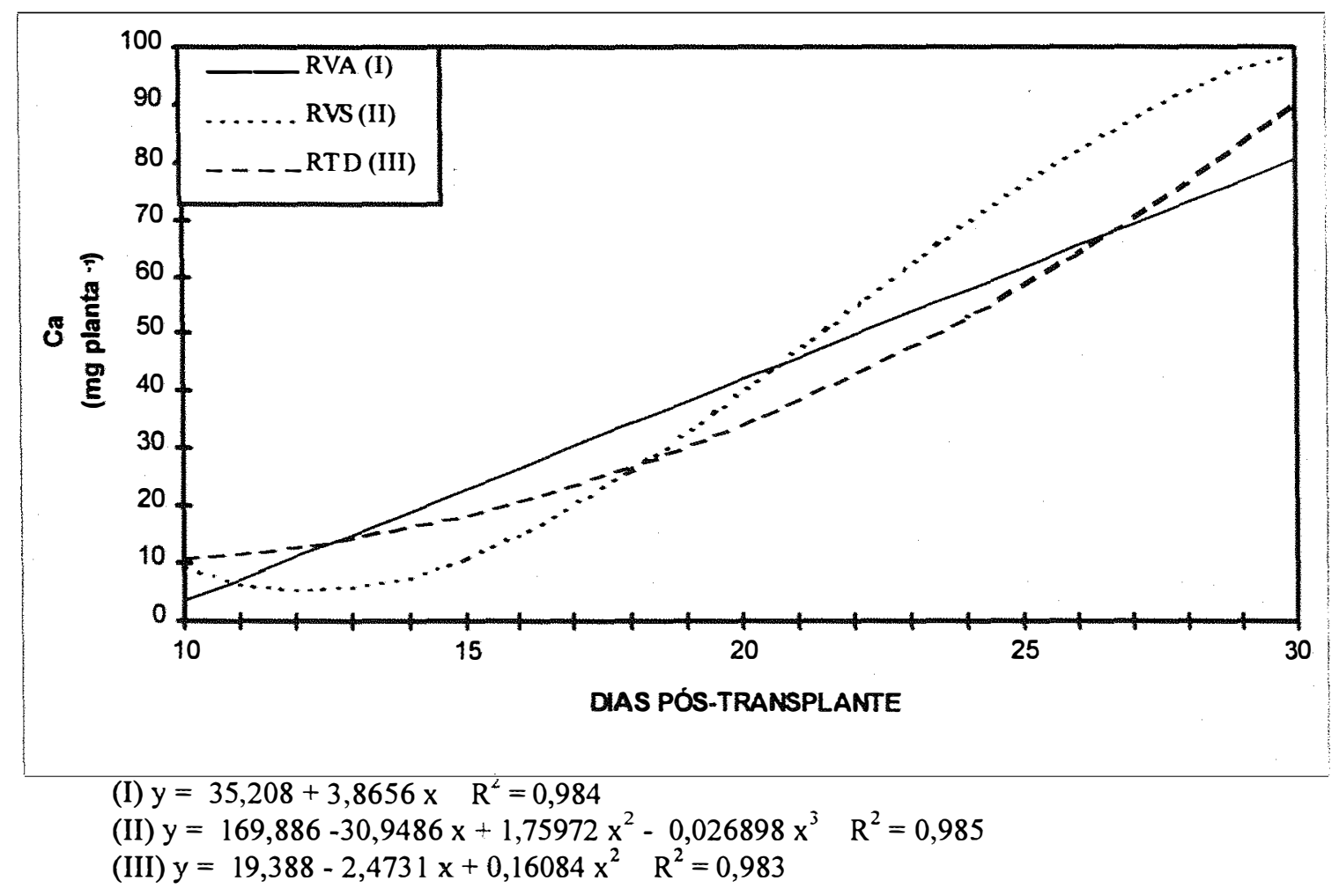

Figura 25. Marcha de absorção do cálcio para a alface cultivar Verônica, em "NFT", sob três formas de manejo da solução nutritiva, no período do transplante até a colheita.

\subsubsection{Magnésio}

As concentrações de magnésio não diferiram entre a RVA e a RTD aos 10 e 15 dpt (Tabela 11). A partir dos 20 dpt na RVA a concentração diferiu dos 
demais tratamentos até a colheita. A RVS e RTD não diferiram entre si aos 20 e $30 \mathrm{dpt}$.

As concentrações de magnésio encontradas nos tratamentos, no $30^{\circ} \mathrm{dpt}$, corresponderam à metade dos valores encontrados por Faquin et al. (1996). Esse comportamento foi semelhante ao observado para o cálcio, portanto, as recomendações sugeridas para aquele nutriente valem também para o magnésio.

Tabela 11 - Concentrações de magnésio no material seco e quantidades absorvidas pela alface cultivar Verônica, em "NFT", em cinco épocas de amostragem.

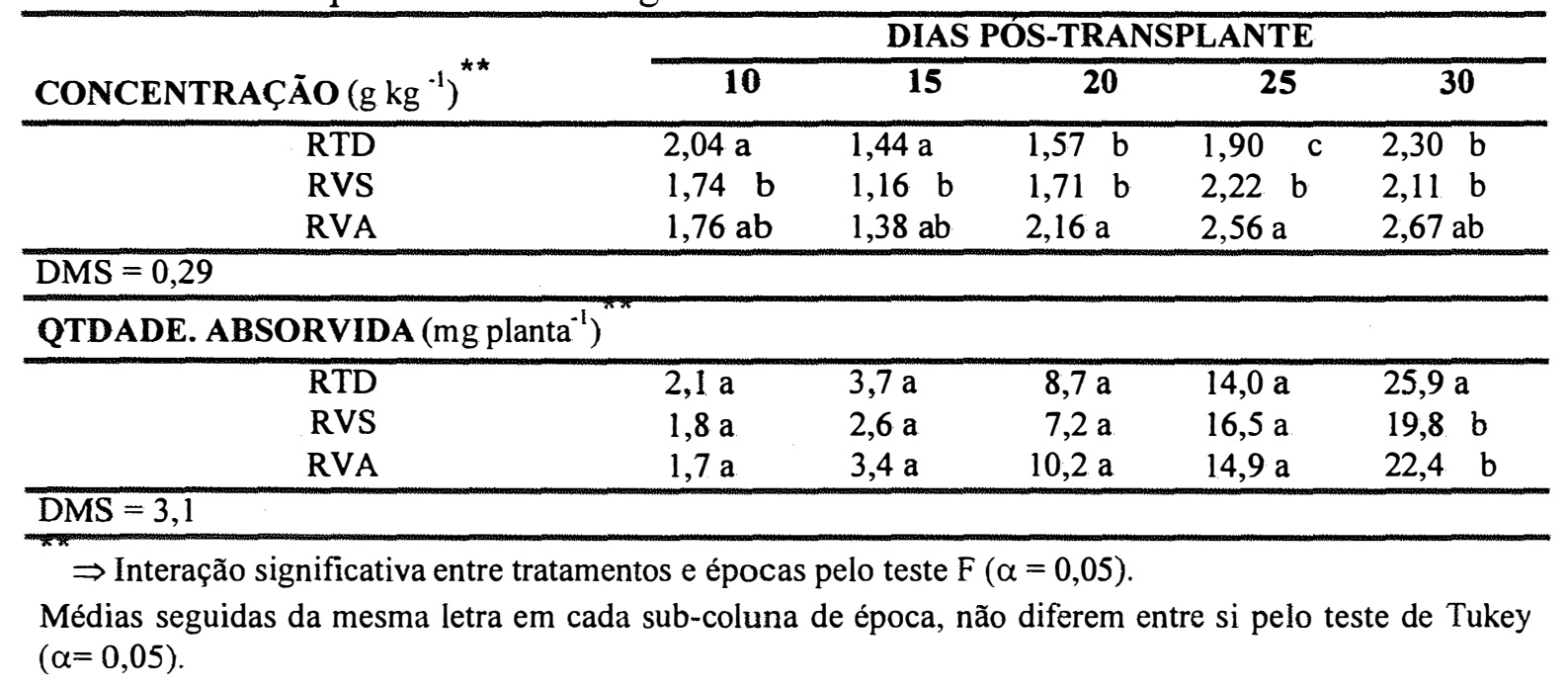

$\mathrm{Na}$ quantidade absorvida de magnésio houve diferença significativa entre os tratamentos na colheita, quando a absorção foi maior na RTD, que diferiu significativamente das demais formas de manejo (Tabela 11). As quantidades absorvidas de magnésio assim como as concentrações, apresentaram a metade do valor encontrado por Faquin et al. (1996) para a mesma cultivar de alface, aos 30 dpt. Portanto a recomendação feita para o cálcio serve também para o magnésio ou seja ou aumenta-se a concentração de magnésio na solução inicial ou reduz-se a de potássio para facilitar a absorção do magnésio pela alface. 
A marcha de absorção do magnésio seguiu um comportamento quadrático e semelhante na RVA e na RTD, como pode-se ver na figura 26. A RVS apresentou um comportamento de curva cúbica.

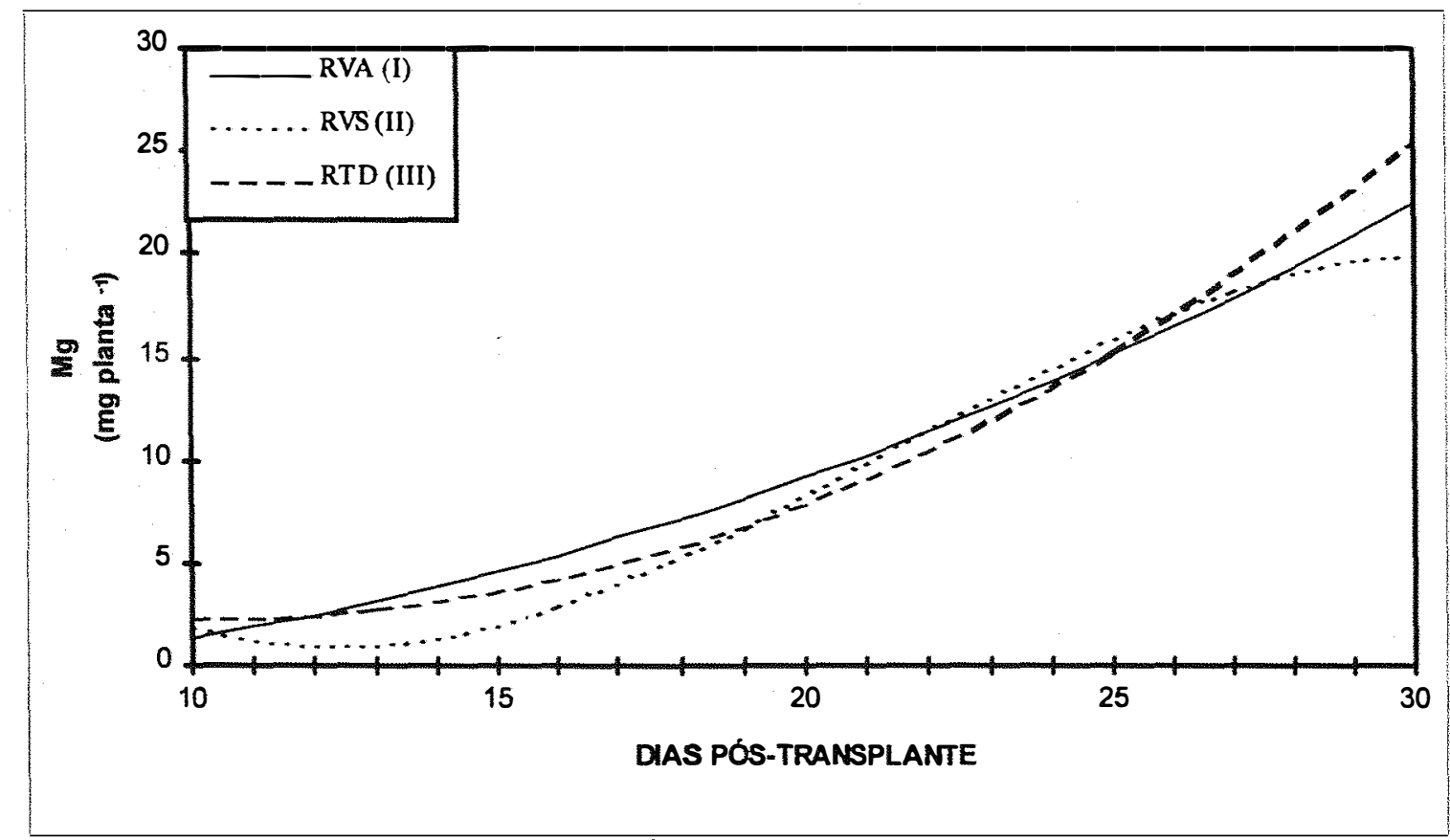

(I) $y=-1,033-0,0332 x+0,02718 x^{2} \quad R^{2}=0,991$

(II) $y=40,673-7,4287 x+0,42186 x^{2}-0,006576 x^{3} \quad R^{2}=0,992$

(III) $y=8,63-1,2266 x+0,05954 x^{2} \quad R^{2}=0,993$

Figura 26. Marcha de absorção do magnésio para a alface cultivar Verônica, em "NFT", sob três formas de manejo da solução nutritiva, no período do transplante até a colheita.

\subsubsection{Enxofre}

Não se observou efeito significativo para interação entre épocas e tratamentos (Tabela 12) e nem se observou diferença significativa entre os tratamentos, tanto para a concentração de enxofre no MS como para as quantidades absorvidas desse elemento (Anexo B3). 
Faquin et al. (1996) obtiveram valor maior que os observados nos tratamentos estudados neste trabalho (Tabela 12) para a concentração de enxofre no MS da alface cultivar Verônica, no $30^{\circ} \mathrm{dpt}$.

Tabela 12 - Concentrações de enxofre no material seco e quantidades absorvidas pela alface cultivar Verônica, em "NFT", em cinco épocas de amostragem.

\begin{tabular}{cccccc}
\hline \multirow{2}{*}{ CONCENTRAÇÃO $\left(\mathrm{g} \mathrm{kg}^{-1}\right)^{\text {NS }}$} & \multicolumn{5}{c}{ DIAS POS-TRANSPLANTE } \\
\cline { 2 - 6 } & $\mathbf{1 0}$ & $\mathbf{1 5}$ & $\mathbf{2 0}$ & $\mathbf{2 5}$ & $\mathbf{3 0}$ \\
\hline RTD & 1,83 & 1,63 & 1,74 & 2,10 & 2,37 \\
RVS & 1,78 & 1,69 & 1,48 & 2,15 & 2,26 \\
RVA & 1,71 & 1,60 & 1,38 & 2,02 & 2,27 \\
\hline QTDADE. ABSORVIDA (mg planta $\left.{ }^{-1}\right)^{1,5}$ & & & & & \\
\hline RTD & 1,9 & 4,1 & 9,3 & 15,8 & 23,7 \\
RVS & 1,9 & 3,9 & 6,4 & 15,9 & 21,3 \\
RVA & 2,6 & 3,8 & 6,5 & 11,8 & 19,4 \\
\hline
\end{tabular}

$\cdots$ Interação não significativa entre tratamentos e épocas pelo teste $F(\alpha=0,05)$.

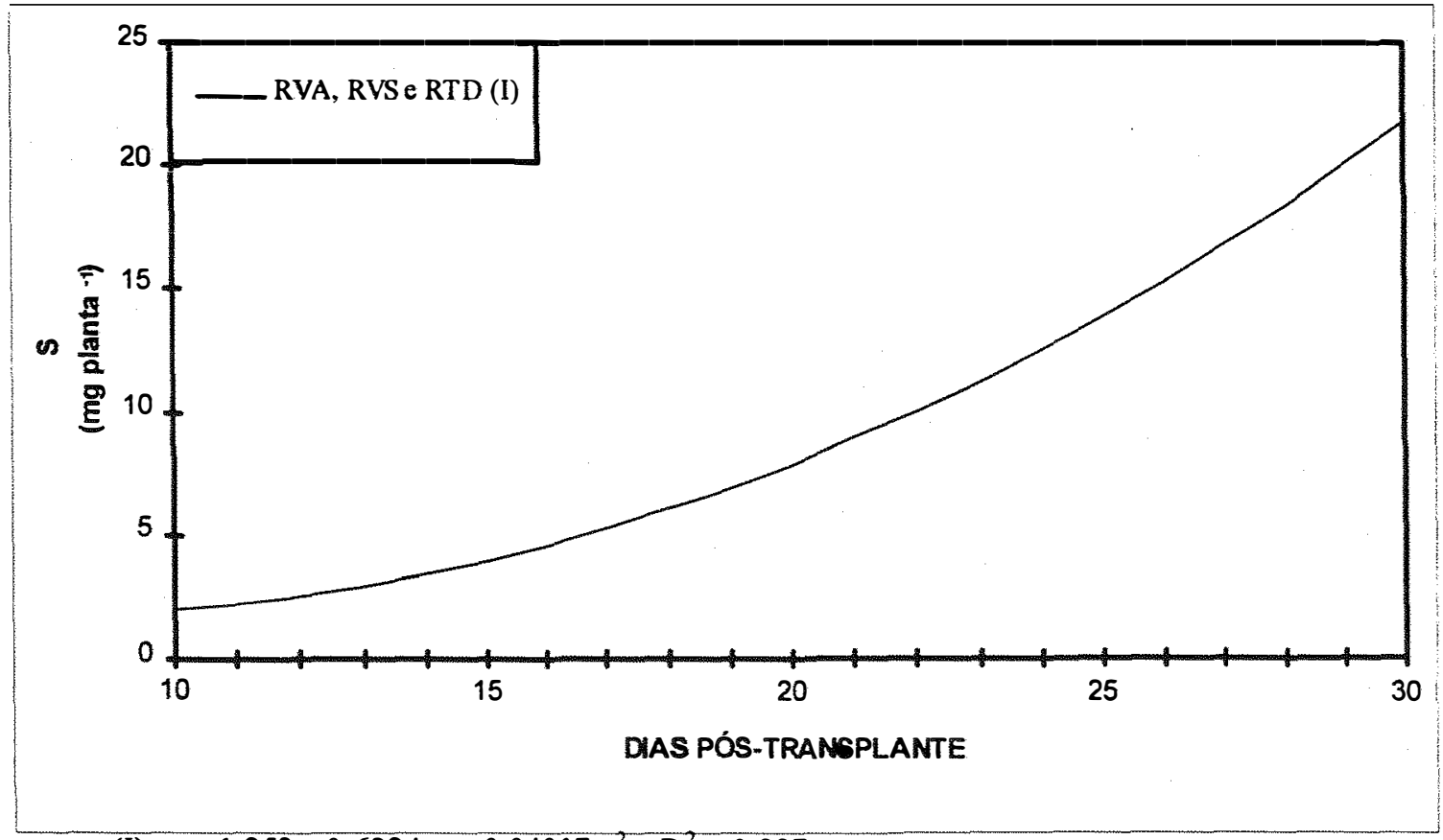

(I) $y=1,253-0,6224 x+0,04017 x^{2} \quad R^{2}=0,997$

Figura 27. Marcha de absorção do enxofre para a alface cultivar Verônica, em "NFT", média das três formas de manejo da solução nutritiva, no período do transplante até a colheita. 
As quantidades absorvidades de enxofre obtidas nos tratamentos tiveram valores menores que os observados por Faquin et al. (1996).

$\mathrm{Na}$ figura 27 pode-se observar a marcha de absorção do enxofre que seguiu um comportamento quadrático, sendo a absorção mais lenta no início (até $15 \mathrm{dpt})$ e mais rápida até a colheita.

\subsubsection{Boro}

Para as concentrações de boro no MS não se observou efeito significativo para a interação entre as épocas e os tratamentos (Tabela 13). Analisando somente os tratamentos não se detectou diferença significativa entre eles (Anexo B3).

Tabela 13 - Concentrações de boro no material seco e quantidades absorvidas pela alface cultivar Verônica, em "NFT", em cinco épocas de amostragem.

\begin{tabular}{|c|c|c|c|c|c|}
\hline \multirow[b]{2}{*}{ CONCENTRAÇÃO $\left(\mathrm{mg} \mathrm{kg}^{-1}\right)$ NS } & \multicolumn{5}{|c|}{ DIAS POS-TRANSPLANTE } \\
\hline & 10 & 15 & 20 & 25 & 30 \\
\hline RTD & 35,7 & 30,0 & 27,0 & 41,4 & 37,4 \\
\hline RVS & 40,1 & 32,5 & 32,9 & 42,3 & 37,8 \\
\hline RVA & 35,6 & 30,7 & 27,4 & 40,5 & 39,1 \\
\hline \multicolumn{6}{|c|}{ QTDADE. ABSORVIDA $\left(\mathrm{mg} \text { planta }^{-1}\right)^{\mathrm{NS}}$} \\
\hline RTD & 0,0372 & 0,0758 & 0,1560 & 0,3071 & 0,3305 \\
\hline RVS & 0,0422 & 0,0740 & 0,1399 & 0,3129 & 0,3579 \\
\hline RVA & 0,0352 & 0,0767 & 0,01291 & 0,2305 & 0,3712 \\
\hline
\end{tabular}

As concentrações de boro no MS da planta inteira de alface na colheita (Tabela 13), foram um pouco maiores que os encontrados por Faquin et al. (1996) para a cultivar Verônica no $30^{\circ} \mathrm{dpt}$. Isso comprova que as quantidades de boro fornecidas na solução inicial foram suficientes para suprir as exigências da alface durante todo o ciclo. 
A quantidade de boro absorvida seguiu o mesmo comportamento que as concentrações, não diferindo estatisticamente entre tratamentos (Anexo B3). As quantidades de boro absorvidas nos tratamentos estudados tiveram valores menores mas, próximos aos encontrados por Faquin et al. (1996).

A marcha de absorção desse elemento seguiu um comportamento cúbico, apresentando uma certa estabilidade quase até os $15 \mathrm{dpt}$, para depois aumentar linearmente até a colheita, mas estabilizando-se próximo a ela (Figura 28).

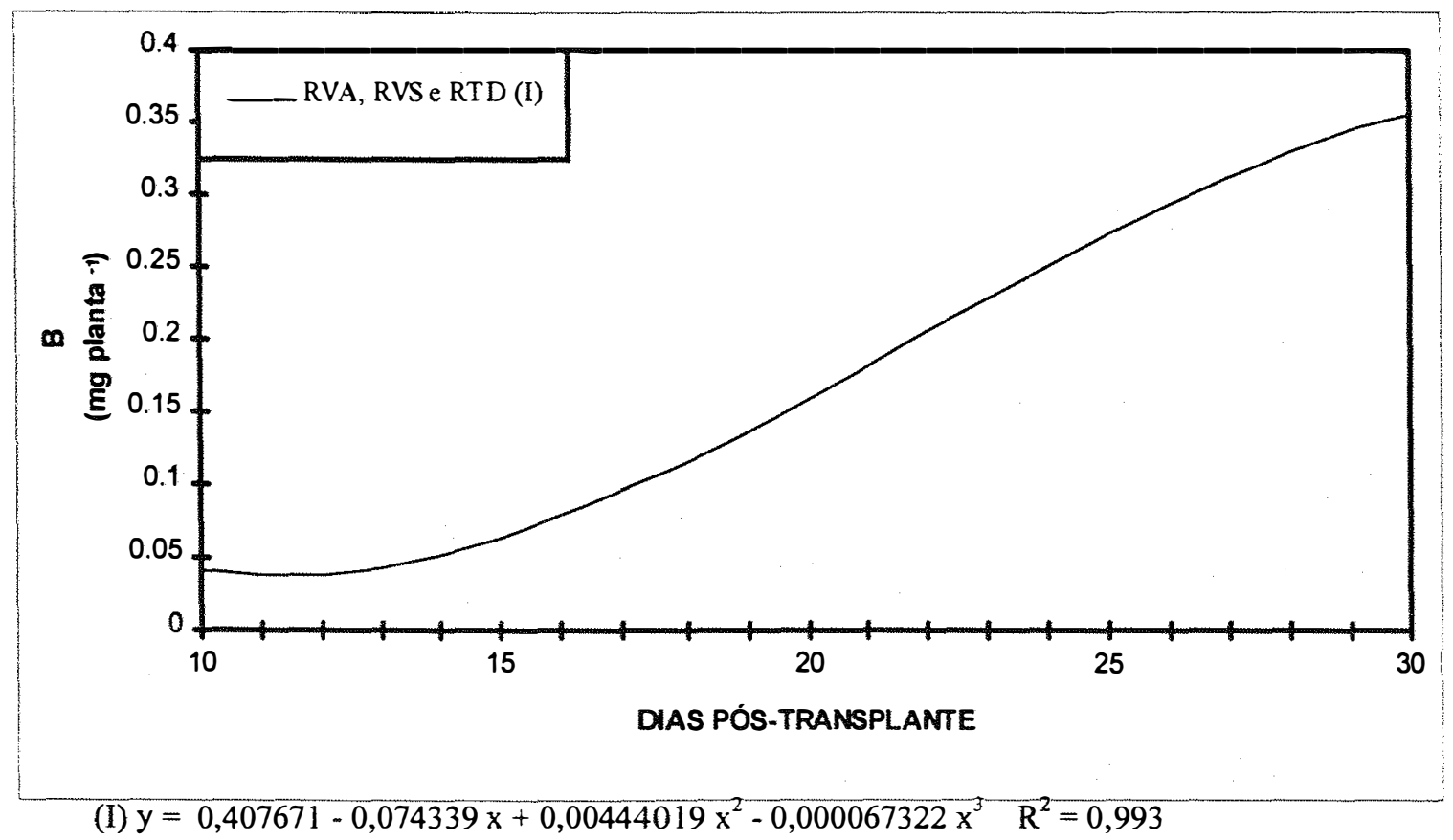

Figura 28. Marcha de absorção do boro para a alface cultivar Verônica, em "NFT", média das três formas de manejo da solução nutritiva, no período do transplante até a colheita.

\subsubsection{Cobre}

A concentração de cobre no MS da alface foi maior na RVS aos 10 e 20 dpt e semelhante à RVA aos 15 e $25 \mathrm{dpt}$ (Tabela 14). Na RTD a concentração de cobre diferiu dos demais manejos até $25 \mathrm{dpt}$ e aos $30 \mathrm{dpt}$ igualou-se aos mesmos. 
Faquin et al. (1996) encontraram valores maiores para as concentrações de cobre em alface da cultivar Verônica no $30^{\circ} \mathrm{dpt}$, que os obtidos nos tratamentos deste trabalho porém, não identificaram sintomas de toxicidade desse elemento.

Tabela 14 - Concentrações de cobre no material seco e quantidades absorvidas pela alface cultivar Verônica, em "NFT", em cinco épocas de amostragem.

\begin{tabular}{|c|c|c|c|c|c|}
\hline \multirow[b]{2}{*}{$\operatorname{CONCENTRAÇÃO}\left(\mathrm{mg} \mathrm{kg}^{-1}\right)^{\star \star}$} & \multicolumn{5}{|c|}{ DIAS POS-TRANSPLANTE } \\
\hline & 10 & 15 & 20 & 25 & 30 \\
\hline RTD & $13,7 \mathrm{c}$ & $4,1 \mathrm{~b}$ & 29,7 & $21,0 \quad b$ & $34,6 \mathrm{a}$ \\
\hline RVS & 98,1 a & $59,2 \mathrm{a}$ & $110,2 \mathrm{a}$ & $68,4 \mathrm{a}$ & $52,3 \mathrm{a}$ \\
\hline RVA & $64,0 \mathrm{~b}$ & $48,7 \mathrm{a}$ & $60,6 \mathrm{~b}$ & $70,1 \mathrm{a}$ & $52,0 \mathrm{a}$ \\
\hline \multicolumn{6}{|l|}{$\overline{D M S}=21,49$} \\
\hline \multicolumn{6}{|c|}{ QTDADE. ABSORVIDA (mg planta $\left.{ }^{-1}\right)^{\text {NS }}$} \\
\hline RTD & 0,0141 & 0,1060 & 0,1492 & 0,1568 & 0,3419 \\
\hline RVS & 0,0104 & 0,1365 & 0,4762 & 0,4906 & 0,4721 \\
\hline RVA & 0,0634 & 0,1211 & 0,2870 & 0,4088 & 0,4063 \\
\hline
\end{tabular}

$\mathrm{NS} \Rightarrow$ Interação não significativa entre tratamentos e épocas pelo teste $\mathrm{F}(\alpha=0,05)$.

$\Rightarrow$ Interação significativa entre tratamentos e épocas pelo teste $F(\alpha=0,05)$.

Médias seguidas da mesma letra em cada sub-coluna de época, não diferem entre si pelo teste de Tukey $(\alpha=0,05)$.

Para as quantidades de cobre absorvidas não se detectou interação entre tratamentos e épocas (Tabela 14). Analisando os tratamentos ocorreu diferença significativa entre os três, sendo observado o maior valor na RVS e o menor na RTD (Anexo B3). O valor observado por Faquin et al. (1996) para a quantidade de cobre absorvida pela cultivar Verônica no $30^{\circ} \mathrm{dpt}$, foi semelhante ao obtido na RVA.

A marcha de absorção do cobre seguiu um comportamento cúbico, sendo que o incremento foi pequeno no início, passando a uma fase de rápida absorção dos 12 aos $25 \mathrm{dpt}$, para diminuir o ritmo próximo à colheita (Figura 29). 


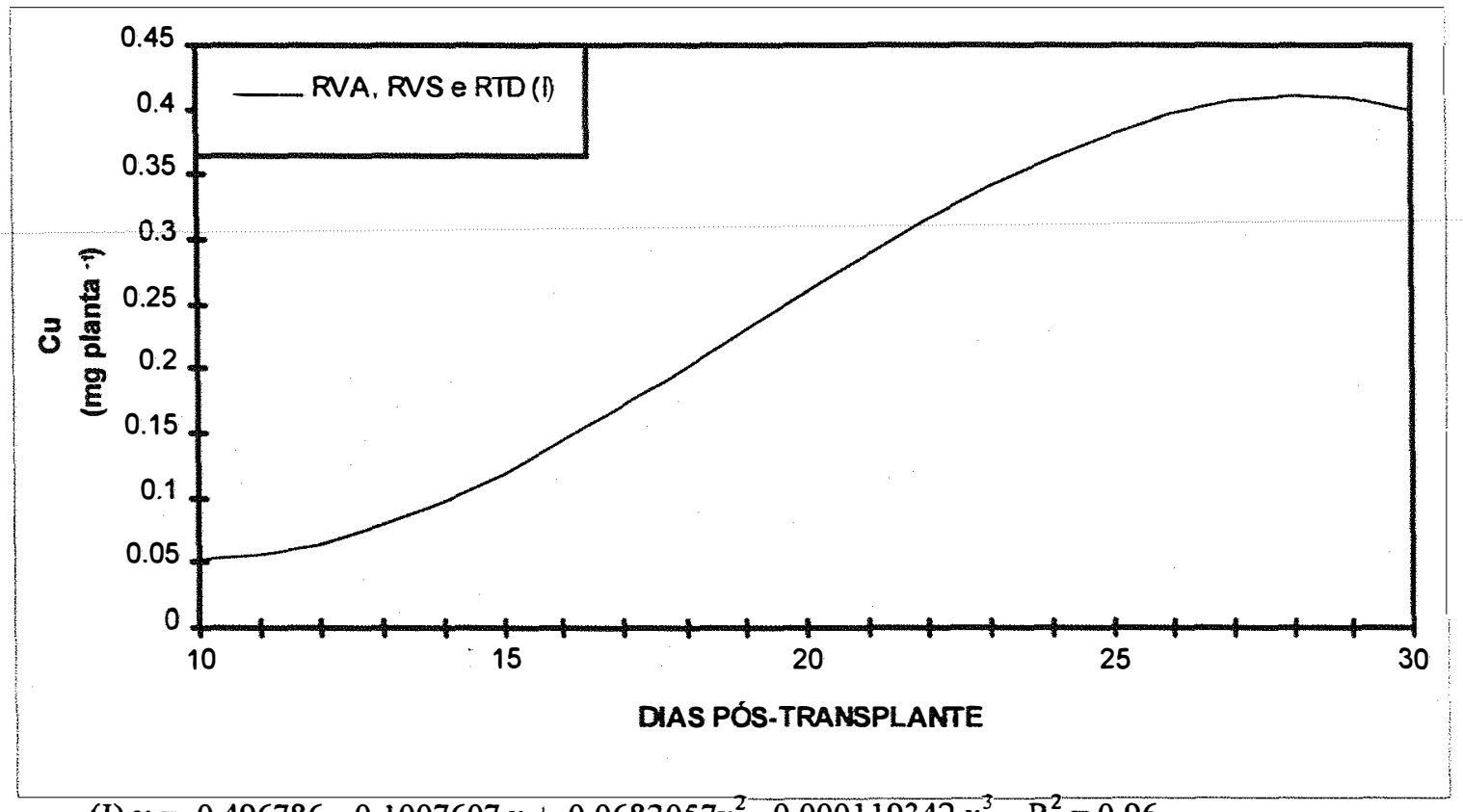

(I) $y=0,496786-0,1007607 x+0,0683057 x^{2}-0,000119342 x^{3}-R^{2}=0,96$

Figura 29. Marcha de absorção do cobre para a alface cultivar Verônica, em "NFT", média das três formas de manejo da solução nutritiva, no período do transplante até a colheita.

\subsubsection{Ferro}

A concentração de ferro no MS da alface no $10^{\circ} \mathrm{dpt}$ foi maior na RTD. No $15^{0}$ e $25^{\circ} \mathrm{dpt}$ os maiores valores foram observados na RTD e na RVS porém, a RVS não diferiu estatisiticamente da RVA. No $20^{\circ} \mathrm{dpt}$ e na colheita não observou-se diferença significativa entre os tratamentos (Tabela 15).

Os valores obtidos para a concentração de ferro na planta inteira no $30^{\circ}$ dpt nos tratamentos deste trabalho, foram praticamente quatro vezes maiores que os valores obtidos por Faquin et al. (1996), que para esse elemento apresentaram somente a concentração nas folhas de alface. Isso pode ser justificado em função de tratar-se da comparação da composição de uma parte da planta (folha) com a composição do todo (planta inteira) e demonstra a inviabilidade da comparação desses valores para efeito da avaliação do estado nutricional. 
Tabela 15 - Concentrações de ferro no material seco e quantidades absorvidas pela alface, cultivar Verônica, em "NFT", em cinco épocas de amostragem.

\begin{tabular}{|c|c|c|c|c|c|}
\hline \multirow[b]{2}{*}{$\operatorname{CONCENTRAÇÃO}\left(\mathrm{mg} \mathrm{kg}^{-1}\right){ }^{\text {** }}$} & \multicolumn{5}{|c|}{ DIAS POS-TRANSPLANTE } \\
\hline & 10 & 15 & 20 & 25 & 30 \\
\hline RTD & $2080,2 \mathrm{a}$ & $1065,6 a$ & $1140,0 \mathrm{a}$ & $1079,4 \mathrm{ab}$ & $1077,2 \mathrm{a}$ \\
\hline RVS & $1323,2 \mathrm{~b}$ & $952,8 \mathrm{ab}$ & $1268,4 \mathrm{a}$ & $1264,4 \mathrm{a}$ & $1054,8 \mathrm{a}$ \\
\hline RVA & $1408,6 \quad b$ & 856,0 b & 1081,2 a & $968,8 \quad b$ & $966,8 \mathrm{a}$ \\
\hline \multicolumn{6}{|l|}{ DMS $=208,36$} \\
\hline \multicolumn{6}{|c|}{ QTDADE. ABSORVIDA (mg planta $\left.{ }^{-1}\right)$} \\
\hline RTD & $2,1498 \mathrm{a}$ & $2,7396 a$ & $6,4032 \mathrm{a}$ & $8,0440 a$ & $10,7615 \mathrm{a}$ \\
\hline RVS & $1,3968 \mathrm{a}$ & $2,2191 \mathrm{a}$ & $5,3540 \mathrm{a}$ & $9,3439 a$ & $9,9805 \mathrm{ab}$ \\
\hline RVA & $0,3937 \mathrm{a}$ & $2,1319 \mathrm{a}$ & $5,0914 \mathrm{a}$ & $5,6474 \quad b$ & $8,5245 \mathrm{~b}$ \\
\hline
\end{tabular}

$\Rightarrow$ Interação significativa entre tratamentos e épocas pelo teste $F(\alpha=0,05)$.

Médias seguidas da mesma letra em cada sub-coluna de época, não diferem entre si pelo teste de Tukey $(\alpha=0,05)$.

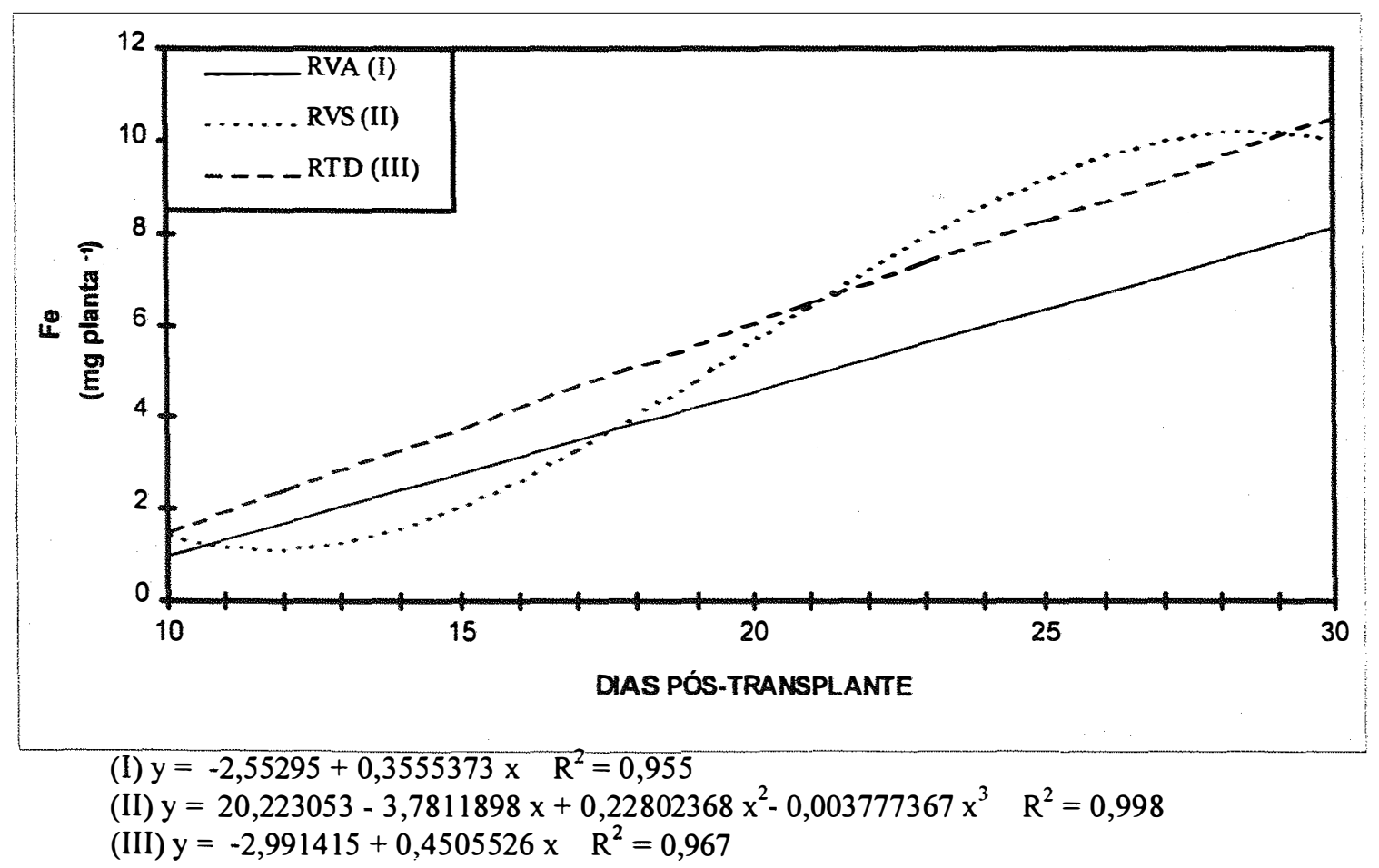

Figura 30. Marchas de absorção do ferro para a alface do cultivar Verônica, em "NFT", sob 3 formas de manejo da solução nutritiva, no período do transplante á colheita. 
As quantidades absorvidas de ferro não apresentaram diferença significativa até o $20^{\circ} \mathrm{dpt}$ (Tabela 15). Aos $25 \mathrm{dpt}$ a RVA teve o menor valor e diferiu dos demais tratamentos. Na colheita a RTD e a RVS tiveram o maior valor de ferro absorvido diferindo da RVA. Esse efeito pode ser atribuído à quantidade de MS produzido uma vez que as concentrações no MS não diferiram entre si significativamente.

A marcha de absorção seguiu um comportamento linear crescente para a RVA e RTD, sendo o incremento maior na RTD (Figura 30). A RVS apresentou um comportamento cúbico, sendo quase estável na fase inicial, passando a uma rápida absorção até os 25 dias e voltando a se estabilizar até a colheita.

\subsubsection{Manganês}

Tabela 16 - Concentrações de manganês no material seco e quantidades absorvidas pela alface cultivar Verônica, em "NFT", em cinco épocas de amostragem.

\begin{tabular}{|c|c|c|c|c|c|}
\hline \multirow[b]{2}{*}{ CONCENTRAÇÃO $\left(\mathrm{mg} \mathrm{kg}^{-1}\right)^{* *}$} & \multicolumn{5}{|c|}{ DIAS POS-TRANSPLANTE } \\
\hline & 10 & 15 & 20 & 25 & 30 \\
\hline RTD & $95,6 \quad b$ & $52,4 \quad b$ & $63,0 \quad b$ & $59,3 \mathrm{~b}$ & $73,0 \quad b$ \\
\hline RVS & $94,4 \quad b$ & $51,8 \quad b$ & $103,8 \mathrm{a}$ & $102,4 \mathrm{a}$ & $110,1 \mathrm{a}$ \\
\hline RVA & $113,9 \mathrm{a}$ & 94,4 a & $115,9 \mathrm{a}$ & $117,5 \mathrm{a}$ & $122,1 \mathrm{a}$ \\
\hline \multicolumn{6}{|l|}{$\mathrm{DMS}=17,28$} \\
\hline \multicolumn{6}{|c|}{ QTDADE. ABSORVIDA (mg planta $\left.{ }^{-1}\right)$} \\
\hline RTD & $0,0951 \mathrm{a}$ & $0,1326 a$ & $0,3486 \mathrm{~b}$ & $0,4480 \mathrm{~b}$ & $0,7128 \mathrm{~b}$ \\
\hline RVS & $0,0996 \mathrm{a}$ & $0,1196 \mathrm{a}$ & $0,4464 \mathrm{ab}$ & $0,7513 \mathrm{a}$ & $1,0078 \mathrm{a}$ \\
\hline RVA & $0,1173 \mathrm{a}$ & $0,2326 \mathrm{a}$ & $0,5447 \mathrm{a}$ & $0,6693 \mathrm{a}$ & $1,0047 \mathrm{a}$ \\
\hline \multicolumn{6}{|l|}{$\mathrm{DMS}=0,1726$} \\
\hline
\end{tabular}

A concentração de manganês no MS da alface foi sempre menor na RTD com exceção dos 10 e 15 dpt (Tabela 16). A RVS apresentou concentrações 
semelhantes à RTD nos 10 e 15 dpt. A RVA e a RVS não diferiram estatisticamente entre si nos, 20 e 25 e 30 dpt.

Os valores das concentrações de manganês encontrados por Faquin et al. (1996) no MS da planta inteira de alface, da cultivar Verônica no $30^{\circ} \mathrm{dpt}$, foram semelhantes aos valores encontrados nos tratamentos RVA e RVS do presente trabalho.

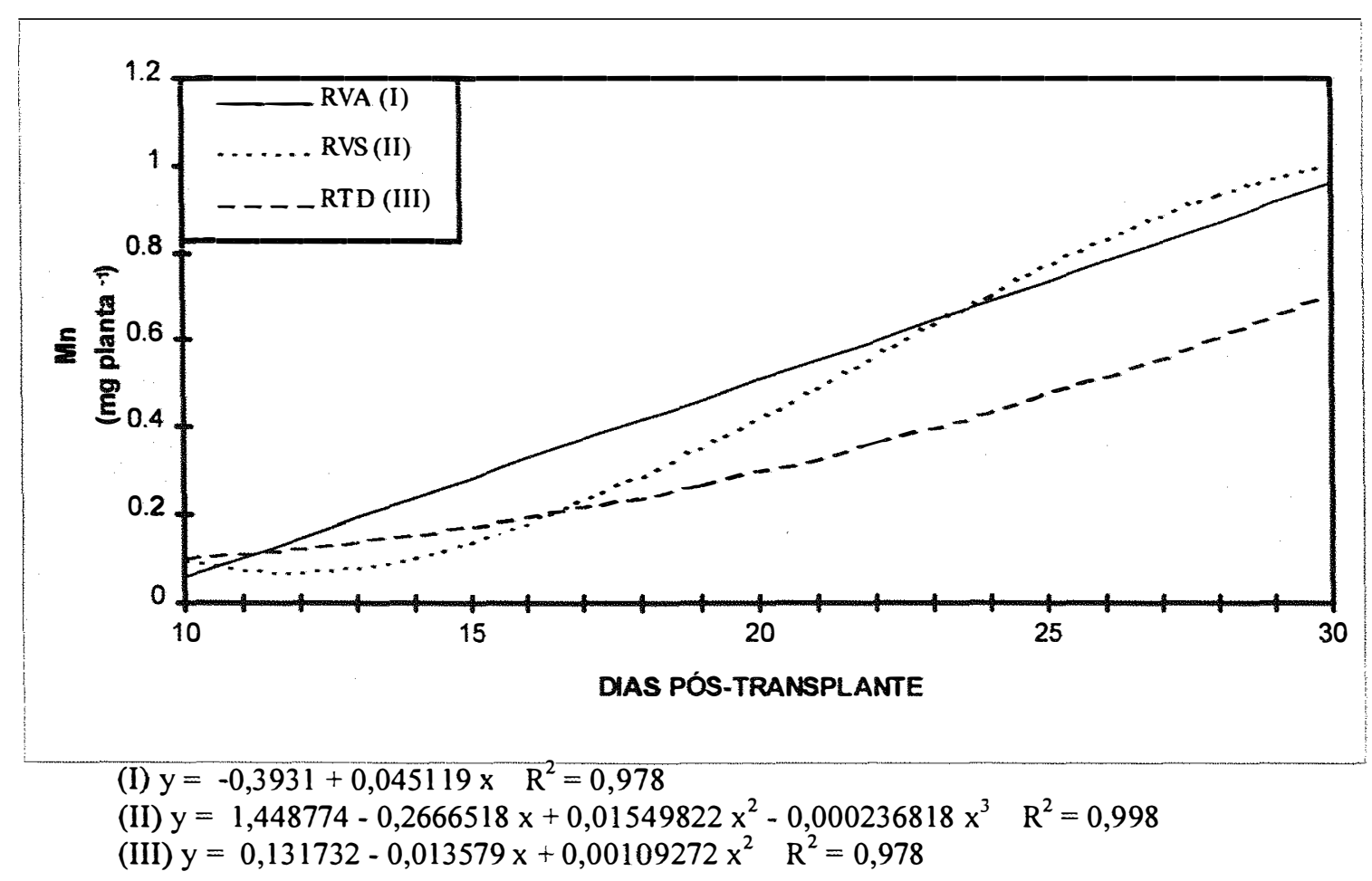

Figura 31. Marcha de absorção do manganês para a alface cultivar Verônica, em "NFT", sob três formas de manejo da solução nutritiva, no período do transplante á colheita.

A quantidade de manganês absorvida não diferiu significativamente entre os tratamentos aos 10 e $15 \mathrm{dpt}$ (Tabela 16). A partir dos $20 \mathrm{dpt}$ observou-se uma redução na quantidade de manganês absorvida na RTD que resultou em diferença significativa entre esse tratamento e os demais no $25^{\circ}$ e $30^{\circ} \mathrm{dpt}$. A RVA e a RVS 
não apresentaram diferença significativa em todas as amostragens. As quantidades de manganês absorvidas na RVA e na RVS foram semelhantes às encontradas por Faquin et al. (1996).

A marcha de absorção do manganês seguiu um comportamento linear progressivo para a RVA (Figura 31). Para a RVS apresentou um comportamento cúbico, inicialmente absorvendo o manganês lentamente (até $15 \mathrm{dpt}$ ) para depois acelerar a absorção até a colheita. Na RTD, a absorção seguiu um comportamento quadrático, sendo inicialmente lenta (até $15 \mathrm{dpt}$ ) e aumentando gradativamente até a colheita.

\subsubsection{Zinco}

Tabela 17 - Concentrações de zinco no material seco e quantidades absorvidas pela alface cultivar Verônica, em "NFT", em cinco épocas de amostragem.

\begin{tabular}{|c|c|c|c|c|c|}
\hline \multirow[b]{2}{*}{ CONCENTRAÇÃO $\left(\mathrm{mg} \mathrm{kg}^{-1}\right)^{\star \star}$} & \multicolumn{5}{|c|}{ DIAS POS-TRANSPLANTE } \\
\hline & 10 & 15 & 20 & 25 & 30 \\
\hline RTD & $74,2 \quad b$ & $50,6 \mathrm{~b}$ & $112,0 \mathrm{a}$ & $76,3 \quad b$ & $182,3 \mathrm{a}$ \\
\hline RVS & $112,6 \mathrm{a}$ & $115,6 \mathrm{a}$ & $113,2 \mathrm{a}$ & $174,1 \mathrm{a}$ & $205,3 \mathrm{a}$ \\
\hline RVA & $116,5 \mathrm{a}$ & $148,5 \mathrm{a}$ & $146,3 \mathrm{a}$ & $197,4 \mathrm{a}$ & $222,9 \mathrm{a}$ \\
\hline \multicolumn{6}{|l|}{$\overline{\mathrm{DMS}}=45,30$} \\
\hline \multicolumn{6}{|c|}{ QTDADE. ABSORVIDA (mg planta ${ }^{-1}$ ) } \\
\hline RTD & $0,0771 \mathrm{a}$ & $0,1313 \mathrm{a}$ & $0,6051 \mathrm{a}$ & $0,5562 \quad b$ & $1,7999 \mathrm{a}$ \\
\hline RVS & $0,1188 \mathrm{a}$ & $0,2695 \mathrm{a}$ & $0,4866 \mathrm{a}$ & $1,2884 \mathrm{a}$ & $1,8790 \mathrm{a}$ \\
\hline RVA & $0,1159 \mathrm{a}$ & $0,3635 \mathrm{a}$ & $0,6936 \mathrm{a}$ & 1,1414 a & $1,8985 \mathrm{a}$ \\
\hline \multicolumn{6}{|l|}{$\mathrm{DMS}=0,3947$} \\
\hline
\end{tabular}

As concentrações de zinco na alface na RVA e na RVS não diferiram significativamente entre si em todas as amostragens, enquanto que diferiram da RTD nos 10, 15 e $25 \mathrm{dpt}$ (Tabela 17). Não houve diferença significativa entre os 
tratamentos aos 20 e $30 \mathrm{dpt}$ para a concentração desse micronutriente. Faquin et al. (1995) encontraram valores quatro vezes menores para as concentrações desse elemento. Isso sugere que houve uma absorção excessiva de zinco embora não se observasse sintomas de toxicidade em nenhum dos tratamentos.

A quantidade de zinco absorvida não apresentou diferença significativa entre os tratamentos até os $20 \mathrm{dpt}$ e aos $30 \mathrm{dpt}$ (Tabela 17). Aos $25 \mathrm{dpt}$ a RTD apresentou a menor quantidade de zinco absorvida diferindo dos demais tratamentos. As quantidades de zinco absorvidas dpt pela alface até o $30^{\circ}$ nos tratamentos estudados foram praticamente quatro vezes maiores que as obtidas por Faquin et al. (1996), em plantas de alface da mesma cultivar e idade.

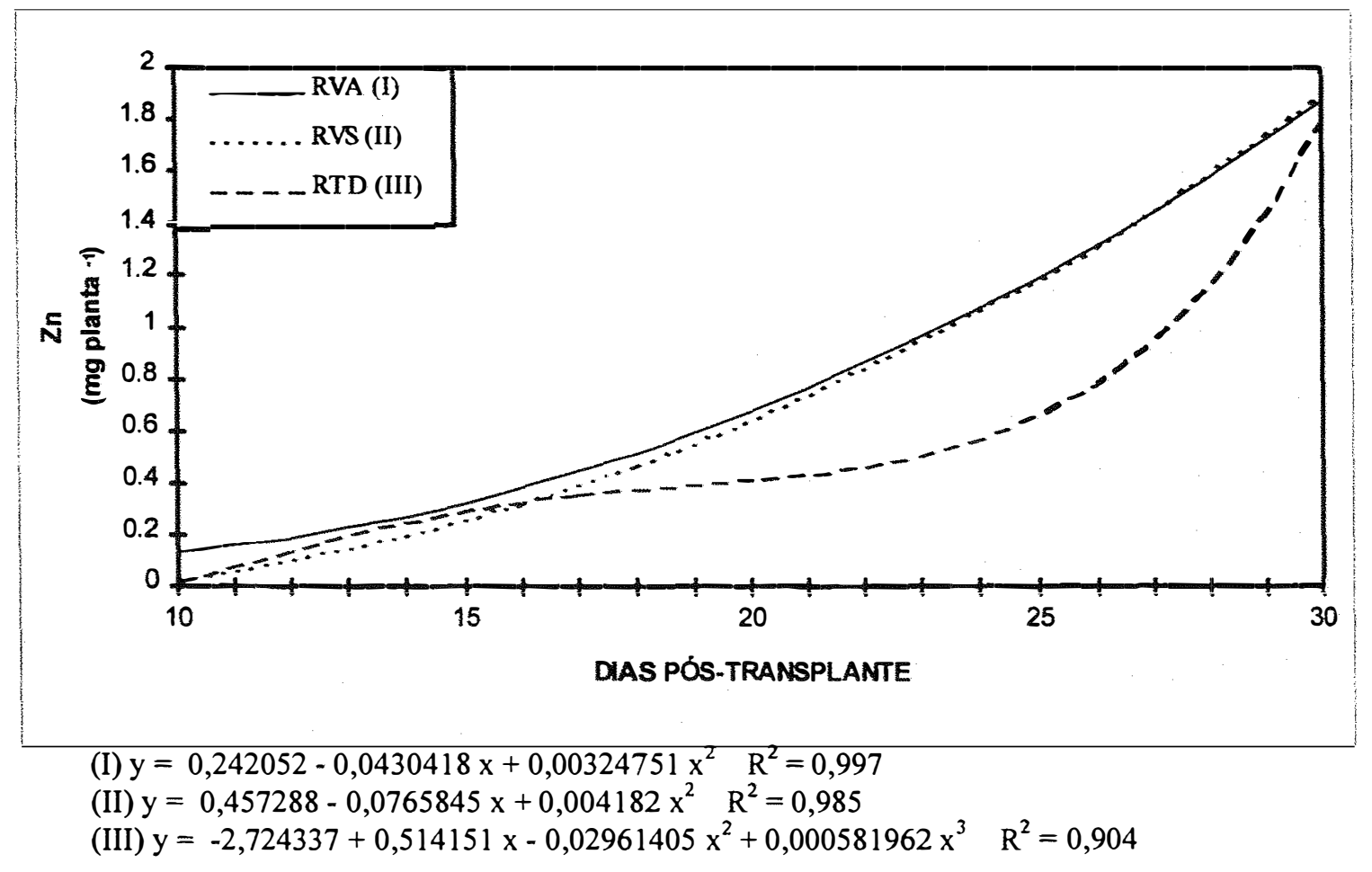

Figura 32. Marcha de absorção do zinco para a alface cultivar Verônica, em "NFT", sob três formas de manejo da solução nutritiva, no período do transplante á colheita. 
A marcha de absorção do zinco foi semelhante na RVA e RVS, aumentando gradativamente e com comportamento curvilíneo quadrático durante o ciclo da alface (Figura 32). Na RTD a marcha de absorção apresentou-se como uma curva cúbica, aumentando até os $15 \mathrm{dpt}$, passando a uma estabilização até os 25 dias, para então aumentar rapidamente até a colheita. 


\section{CONCLUSÕES}

Nas condições em que este trabalho foi realizado e, de acordo com os resultados obtidos, pode-se concluir que:

-A relação de massa de material fresco das raízes/parte aérea e a produção de material seco da planta inteira da alface foram afetados pelo manejo da solução nutritiva, influenciando o consumo de solução nutritiva, enquanto que a produção de material fresco não foi afetada;

-O manejo da solução não afetou as concentrações de enxofre, boro, cobre, ferro e zinco e as quantidades absorvidas de potássio, cálcio, enxofre, boro, cobre e zinco pela alface na colheita e somente o enxofre e o boro não tiveram suas concentrações e quantidades absorvidas afetadas pelos tratamentos em todas as épocas de amostragem;

-O pH, a condutividade elétrica e a concentração de nutrientes da solução foram afetados pelo manejo. 


\section{REFERÊNCIAS BIBLIOGRÁFICAS}

BENOIT, F. Practical guide for simple soilless culture techniques. SintKatelijne-Waver: European Vegetable R \& D Centre, 1992. 72 p.

BENOIT, F; CEUSTERMANS, N. Recommendations for the commercial production of butterhead lettuce in NFT. Soilless Culture, v. 5, n. 1, p. 1-12, 1989.

BIAGLOGWSKI, J. Effect of extent and temperature of roots on transpiration of rooted lemon cuttings. Proceedings of the American Society for Horticultural Science, v. 34, p. 96-102, 1936.

BOON, J. van der; STEENHUIZEN, J.W.; STEINGRÖWER, E. Effect of EC, and $\mathrm{Cl}$ and $\mathrm{NH}_{4}^{+}$concentration of nutrient solutions on nitrate accumulation in lettuce. In: SYMPOSIUM ON THE FERTILIZATION OF VEGETABLES UNDER PROTECTED CULTIVATION, Naaldwijk, 1987. Acta Horticulturae, v. 222, p. 35-41, 1988.

BRES, W.; WESTON, L. A. Nutrient accumulation and tipburn in NFT-grown at several potassium and pH levels. Hortscience, v. 27, n. 7, p. 790-792, 1992. 
BURRAGE, S.W.;VARLEY, M. J. Water relations of lettuce grown in nutrient film culture. In: SYMPOSIUM ON RESEARCH ON RECIRCULATING WATER CULTURE, 1., Littlehampton, 1979. Acta Horticulturae, v. 98, p. 79-86, 1980.

CARMELLO, Q. A. de C.; FURLANI, P.R. Hidroponia: cultivo de plantas sem solo. Piracicaba:ESALQ, 1994. 41 p.

CASTEllane, P. D.; ARAÚJO, J. A. C. de. Cultivo sem terra: hidroponia. Jaboticabal: FUNEP, 1994. 43 p.

CLARK, R. B. Nutrient solution growth of sorghum and corn in mineral nutrition studies. Journal of Plant Nutrition, v. 5, p. 1031-1038, 1982.

DOUGLAS, J.S. Advanced guide to hydroponics: soilless cultivation. 5. ed. London: Pelham Books, 1985. 368 p.

FAQUIN, V.; FURTINI NETO, A. E.; VILELA, L. A. A. Produção de alface em hidroponia. Lavras: UFLA, 1996. 50 p.

FURLANI, P. R. Cultivo de alface pela técnica de hidroponia - NFT. Campinas: Instituto Agronômico, 1995. 18 p. (Documentos IAC, 55). 
GARCÍA, V. N. Sistemas de solución perdida e recirculante. Descripción, análisis y valoración. In: MARTÍNEZ, F. C.; ALVAREZ, J. S. D. (Ed.). Cultivos sin suelo: curso superior de especializacion. Almería: Servicio de Edición del Instituto de Estudios Almerienses, 1993. cap. 3, p. 85-130.

GRAVES, C. J. The nutrient film technique. Horticultural Reviews, v. 5, p.144, 1983.

HANSEN, M. Nutrition of plant according to species and water supply. In: SYMPOSIUM ON RESEARCH ON RECIRCULATING WATER CULTURE, 1., Littlehampton, 1979. Acta Horticulturae, v. 98, p. 99-102, 1980.

HEINEN, M.; JAGER, A. de; NIERS, H. Uptake of nutrients by lettuce on NFT with controlled composition of the nutrient solution. Netherlands Journal of Agricultural Science, v. 9, p. 197-212, 1991.

HUETT, D. O. Growth, nutrient uptake and tipburn severity of hydroponic lettuce in response to electrical conductivity and $\mathrm{Ca}: \mathrm{K}$ ratio in solution. Australian Journal of Agricultural Research, v. 45, p. 251-267, 1994.

JENSEN, M. H; COLLINS, W.L. Hidroponic vegetable production. Horticultural Reviews, v.5, p. 483-558, 1983.

JONES Jr., J. B. Hydroponics: its history and use in plant nutrition studies. Journal of Plant Nutrition, v. 5, n. 8, p. 1003-1030, 1982. 
JONES Jr., J B. A guide for the hydroponic and soilless culture grower. Portland: Timber Press, 1983. 124 p.

MARTINEZ, H. P. M. O cultivo hidropônico de alface (Lactuca sativa L.). In: CASALI, V. W. D. (Coord.): Seminários de olericultura. Viçosa: Imprensa Universitária, v.15, p. 74-111, 1988.

MORGAN, J. V. ; MOUSTAFA, A.T.; SANLAN, F.; TAN, A. Propagation techniques for crops in nutrient solution culture. In: SYMPOSIUM ON RESEARCH ON RECIRCULATING WATER CULTURE, 1., Littlehampton, 1979. Acta Horticulturae, v. 98, p.243-252, 1980.

RESH, H. M. Cultivos hidropónicos: nuevas técnicas de producción. 2. ed. Madrid:Ed. Mundi-Prensa, 1987. 318p.

SARRUGE, J. R. Soluções nutritivas. Summa Phytopathologica, v. 1, p. 231233, 1975.

SARRUGE, J. R.; HAAG, H.P. Análises químicas em plantas. Piracicaba: ESALQ, 1974. 56 p.

SHIPPERS, P. A. Composition changes in the nutrition solution during the growth of plants in recirculating nutrient culture. In: SYMPOSIUM ON RESEARCH ON RECIRCULATING WATER CULTURE, 1., Littlehampton, 1979. Acta Horticulturae, v. 98, p. 103-118, 1980. 
STEINER, A. A. The selective capacity of plants for ions and its importance for the composition and treatment of the nutrient solution. In: SYMPOSIUM ON RESEARCH ON RECIRCULATING WATER CULTURE, 1., Littlehampton, 1979. Acta Horticulturae, v. 98, p. 87-98, 1980.

WILCOX, G.E. The future of hydroponics as a research and plant production method. Journal of Plant Nutrition, v. 5, n. 8, p. 1039-1057, 1982.

WILLUMSEN, J. $\mathrm{pH}$ of the flowing nutrient solution. In: SYMPOSIUM ON RESEARCH ON RECIRCULATING WATER RECIRCULATING WATER CULTURE, 1., Littlehampton, 1979. Acta Horticulturae, v.98, p. 191-200, 1980.

WILSON, G. C. S. Effect of $\mathrm{N}: \mathrm{K}$ ratio in a hydroponic situation. In: SYMPOSIUM ON RESEARCH ON RECIRCULATING WATER CULTURE, 1., Littlehampton, 1979. Acta Horticulturae, v. 98, p. 161-170, 1980. 
ANEXO: Condições meteorológicas e análises estatísticas. 


\section{ANEXO A}

Tabela A. 1. Condições meteorológicas vigentes na estação meteorológica do Departamento de Física e Meteorologia da ESALQ/USP, de 23 de maio a 22 de junho de 1996.

\begin{tabular}{|c|c|c|c|c|c|c|c|c|}
\hline DATA & $\begin{array}{l}\text { RADIAÇAO } \\
\text { GLOBAL } \\
\text { cal } \mathrm{cm}^{-2} \mathrm{~d}\end{array}$ & INSOLAÇÄO & $\begin{array}{c}\text { UMIDADE } \\
\text { RELATIVA } \\
\%\end{array}$ & $\begin{array}{l}\text { VENTO } \\
\text { MÉDIO } \\
\mathrm{Km} \mathrm{h}^{-1}\end{array}$ & $\begin{array}{l}\text { TEMPER. } \\
\text { MÁXIMA } \\
{ }^{\circ} \mathrm{C}\end{array}$ & $\begin{array}{l}\text { TEMPER. } \\
\text { MINIMA } \\
{ }^{\circ} \mathrm{C}\end{array}$ & $\begin{array}{l}\text { EMPER. } \\
\text { MÉDIA } \\
{ }^{\circ} \mathrm{C}\end{array}$ & $\begin{array}{c}\text { EVAPORAÇĀO } \\
\mathrm{mm}\end{array}$ \\
\hline $23 / \mathrm{mai} / 96(0)$ & 299,00 & 6,30 & 81,00 & 7,80 & 26,60 & 15,80 & 21,20 & 2,19 \\
\hline 24/mai/96(1) & 246,00 & 5,90 & 81,00 & 13,30 & 23,00 & 15,20 & 19,10 & 4,93 \\
\hline 25/mai/96(2) & 324,00 & 7,60 & 73,00 & 7,30 & 23,80 & 9,90 & 16,85 & 3,30 \\
\hline 26/mai/96(3) & 333,00 & 8,70 & 76,00 & 3,20 & 25,10 & 11,40 & 18,25 & 3,14 \\
\hline 27/mai/96(4) & 434,00 & 9,70 & 78,00 & 3,30 & 26,30 & 10,20 & 18,25 & 2,83 \\
\hline 28/mai/96(5) & 312,00 & 6,90 & 77,00 & 4,50 & 25,30 & 9,90 & 17,60 & 2,80 \\
\hline 29/mai/96(6) & 320,00 & 7,80 & 78,00 & 3,80 & 24,90 & 9,10 & 17,00 & 1,79 \\
\hline 30/mai/96(7) & 264,00 & 5,60 & 83,00 & 3,80 & 26,20 & 8,40 & 17,30 & 0,54 \\
\hline 31/mai/96(8) & 321,00 & 9,20 & 71,00 & 7,40 & 28,50 & 10,00 & 19,25 & 4,50 \\
\hline 1/jun/96(9) & 294,00 & 8,50 & 77,00 & 6,50 & 27,80 & 11,90 & 19,85 & 3,18 \\
\hline 2/jun/96(10) & 101,00 & 0,00 & 88,00 & 9,90 & 19,10 & 15,40 & 17,25 & 2,62 \\
\hline 3/jun/96(11) & 314,00 & 8,60 & 76,00 & 10,30 & 23,40 & 9,70 & 16,55 & 3,76 \\
\hline 4/jun/96(12) & 263,00 & 7,50 & 76,00 & 6,30 & 24,50 & 12,40 & 18,45 & 3,02 \\
\hline 5/jun/96(13) & 286,00 & 7,00 & 77,00 & 9,20 & 25,10 & 12,10 & 18,60 & 3,20 \\
\hline 6/jun/96(14) & 201,00 & 3,70 & 91,00 & 6,50 & 22,80 & 12,10 & 17,45 & 1,74 \\
\hline 7/jun/96(15) & 291,00 & 6,70 & 82,00 & 7,40 & 24,90 & 10,50 & 17,70 & 1,59 \\
\hline $8 /$ jun/96(16) & 312,00 & 7,50 & 78,00 & 8,80 & 23,80 & 8,00 & 15,90 & 2,56 \\
\hline 9/jun/96(17) & 342,00 & 9,70 & 77,00 & 8,30 & 24,40 & 10,00 & 17,20 & 3,96 \\
\hline 10/jun/96(18) & 324,00 & 8,30 & 76,00 & 4,40 & 24,60 & 7,80 & 16,20 & 2,68 \\
\hline 11/jun/96(19) & 338,00 & 9,00 & 73,00 & 8,10 & 23,80 & 7,80 & 15,80 & 3,50 \\
\hline 12/jun/96(20) & 360,00 & 9,60 & 73,00 & 9,00 & 25,20 & 7,20 & 16,20 & 3,16 \\
\hline 13/jun/96(21) & 371,00 & 9,60 & 74,00 & 9,50 & 25,20 & 8,40 & 16,80 & 3,06 \\
\hline 14/jun/96(22) & 326,00 & 9,30 & 74,00 & 6,00 & 26,90 & 8,60 & 17,75 & 3,23 \\
\hline 15/jun/96(23) & 338,00 & 9,70 & 73,00 & 7,20 & 27,90 & 10,60 & 19,25 & 3,40 \\
\hline 16/jun/96(24) & 321,00 & 9,30 & 68,00 & 7,30 & 29,90 & 10,50 & 20,20 & 3,83 \\
\hline 17/jun/96(25) & 303,00 & 9,00 & 61,00 & 8,10 & 30,10 & 12,00 & 21,05 & 4,82 \\
\hline 18/jun/96(26) & 324,00 & 9,70 & 66,00 & 7,50 & 31,30 & 11,60 & 21,45 & 4,50 \\
\hline 19/jun/96(27) & 294,00 & 9,60 & 73,00 & 5,90 & 29,80 & 11,20 & 20,50 & 3,48 \\
\hline 20/jun/96(28) & 257,00 & 5,20 & 79,00 & 5,20 & 30,10 & 12,00 & 21,05 & 1,64 \\
\hline 21/jun/96(29) & 299,00 & 7,80 & 67,00 & 7,80 & 29,20 & 12,20 & 20,70 & 5,14 \\
\hline 22/jun/96(30) & 285,00 & 6,80 & 77,00 & 5,10 & 28,00 & 11,20 & 19,60 & 2,42 \\
\hline
\end{tabular}




\section{ANEXO B}

B1

Quadro 1 - Esquema da Análise de Variância (ANOVA) pelo teste $F$.

\begin{tabular}{lc}
\hline CAUSAS DA VARIAÇÃO & G.L. \\
\hline Blocos & 9 \\
Tratamentos & 2 \\
Resíduo (A) & 18 \\
\hline Parcelas & 29 \\
\hline Épocas & 5 \\
Tratamentos x Épocas & 10 \\
Épocas x Blocos & 45 \\
Resíduo (B) & 90 \\
\hline Total & 179 \\
\hline
\end{tabular}

Tabela A. 2. Resultados do teste $\mathrm{F}$ aplicado à análise da variância para os fatores material fresco (MFR) e seco (MSR) de raízes, material fresco(MFPA) e seco (MSPA) de parte aérea e material fresco (MFPI) e seco(MSPI) da planta inteira em gramas de alface cv. Verônica, em "NFT".

\begin{tabular}{ccccccc}
\hline & Tratamento & Epoca & Tratamento & CV Resíduo & CV Resíduo \\
Massa & & & $X$ & $(\mathrm{~A})$ & $(\mathrm{B})$ \\
\cline { 5 - 6 } & & & Época & \multicolumn{3}{c}{$\%$} \\
\hline MFR & 0,00057 & 0,00001 & 0,00181 & 17,43 & 35,05 \\
MSR & 0,03593 & 0,00001 & 0,24720 & 17,65 & 30,72 \\
MFPA & 0,06632 & 0,00001 & 0,10379 & 17,69 & 30,12 \\
MSPA & 0,05001 & 0,00001 & 0,10361 & 18,54 & 29,19 \\
MFPI & 0,26212 & 0,00001 & 0,20667 & 17,28 & 29,51 \\
MSPI & 0,14540 & 0,00001 & 0,20823 & 18,01 & 28,18 \\
\hline
\end{tabular}


B2

Tabela A. 3. Resultados do teste $\mathrm{F}$, aplicado à análise de variância para os fatores concentração de N, P, K, Ca, Mg e S ( $\mathrm{g} \mathrm{kg}^{-1} \mathrm{MS}$ ); B, Cu, Fe, Mn e Zn ( $\left.\mathrm{mg} \mathrm{kg}^{-1} \mathrm{MS}\right)$ na planta inteira de alface cv. Verônica, em "NFT".

\begin{tabular}{|c|c|c|c|c|c|}
\hline & Tratamento & Epoca & $\begin{array}{c}\text { Tratamento } \\
\text { X }\end{array}$ & $\begin{array}{l}\text { CV Resíduo } \\
\text { (A) }\end{array}$ & $\begin{array}{c}\text { CV Resíduo } \\
\text { (B) }\end{array}$ \\
\hline Concentração & & & Época & \multicolumn{2}{|c|}{$\%$} \\
\hline $\mathrm{N}$ & 0,00002 & 0,00001 & 0,05196 & 4,32 & 7,97 \\
\hline$P$ & 0,00001 & 0,00001 & 0,00043 & 4,99 & 13,94 \\
\hline $\mathrm{K}$ & 0,08717 & 0,00001 & 0,00001 & 4,03 & 10,94 \\
\hline $\mathrm{Ca}$ & 0,04356 & 0,00001 & 0,00009 & 6,50 & 14,67 \\
\hline $\mathrm{Mg}$ & 0,00002 & 0,00001 & 0,00003 & 4,88 & 14,49 \\
\hline $\mathrm{S}$ & 0,03989 & 0,00001 & 0,60101 & 5,97 & 14,73 \\
\hline B & 0,02107 & 0,00001 & 0,77693 & 6,27 & 17,29 \\
\hline $\mathrm{Cu}$ & 0,00001 & 0,00003 & 0,00003 & 15,84 & 38,44 \\
\hline $\mathrm{Fe}$ & 0,00025 & 0,00001 & 0,00001 & 7,81 & 16,54 \\
\hline $\mathrm{Mn}$ & 0,00001 & 0,00001 & 0,00001 & 8,45 & 17,67 \\
\hline $\mathrm{Zn}$ & 0,00001 & 0,00001 & 0,00627 & 13,12 & 30,98 \\
\hline
\end{tabular}

Tabela A. 4. Resultado do teste $\mathrm{F}$, aplicado à análise de variância para os fatores absorção de N, P, K, Ca, Mg, S (g planta ${ }^{-1}$ ), B, Cu, Fe, Mn e Zn (mg planta $^{-1}$ ), na massa de material seco (planta inteira) de alface cv. Verônica, em NFT.

\begin{tabular}{|c|c|c|c|c|c|}
\hline Absorção & Tratamento & Epoca & $\begin{array}{c}\text { Tratamento } \\
\text { X }\end{array}$ & $\begin{array}{l}\text { CV Resíduo } \\
\text { (A) }\end{array}$ & $\begin{array}{l}\text { CVResíduo } \\
\text { (B) }\end{array}$ \\
\hline & & & Época & \multicolumn{2}{|c|}{$\%$} \\
\hline $\mathrm{N}$ & 0,00673 & 0,00001 & 0,02059 & 20,01 & 29,78 \\
\hline$P$ & 0,00090 & 0,00001 & 0,00418 & 20,79 & 36,69 \\
\hline $\mathrm{K}$ & 0,83219 & 0,00001 & 0,03485 & 21,33 & 33,24 \\
\hline $\mathrm{Ca}$ & 0,52562 & 0,00001 & 0,01348 & 22,15 & 35,46 \\
\hline $\mathrm{Mg}$ & 0,1123 & 0,00001 & 0,00245 & 12,97 & 27,96 \\
\hline $\mathrm{S}$ & 0,05173 & 0,00001 & 0,09113 & 18,55 & 31,92 \\
\hline $\mathrm{B}$ & 0,311 & 0,00001 & 0,59691 & 24,97 & 38,19 \\
\hline $\mathrm{Cu}$ & 0,00001 & 0,00001 & 0,09949 & 20,86 & 63,58 \\
\hline $\mathrm{Fe}$ & 0,02209 & 0,00001 & 0,0479 & 20,49 & 33,15 \\
\hline $\mathrm{Mn}$ & 0,00086 & 0,00001 & 0,00623 & 17,61 & 35,90 \\
\hline $\mathrm{Zn}$ & 0,04281 & 0,00001 & 0,04429 & 24,02 & 48,37 \\
\hline
\end{tabular}


B3

Tabela A 5. Resultados do teste de Tukey para tratamentos (médias das épocas de amostragem).

\begin{tabular}{lllll}
\hline VARIÁVEL & RTD & RVS & RVA & DMS \\
\hline MS raízes (g) & $0,542 \mathrm{~b}$ & $0,637 \mathrm{a}$ & $0,675 \mathrm{a}$ & 0,09 \\
MF parte aérea $(\mathrm{g})$ & $101,55 \mathrm{a}$ & $89,27 \mathrm{ab}$ & $83,84 \mathrm{~b}$ & 13,21 \\
MS parte aérea $(\mathrm{g})$ & $4,77 \mathrm{a}$ & $4,26 \mathrm{ab}$ & $3,83 \mathrm{~b}$ & 0,60 \\
MF planta inteira $(\mathrm{g})$ & $110,83 \mathrm{a}$ & $101,24 \mathrm{a}$ & $97,74 \mathrm{a}$ & 14,60 \\
MS planta inteira (g) & $5,31 \mathrm{a}$ & $4,89 \mathrm{ab}$ & $4,50 \mathrm{~b}$ & 0,66 \\
Concentração de nitrogênio $\left(\mathrm{g} \mathrm{kg}^{-1}\right)$ no MS & $46,00 \mathrm{a}$ & $40,96 \mathrm{~b}$ & $40,11 \mathrm{~b}$ & 1,61 \\
Concentração de enxofre $\left(\mathrm{g} \mathrm{kg}^{-1}\right)$ no MS & $1,93 \mathrm{a}$ & $1,87 \mathrm{ab}$ & $1,79 \mathrm{~b}$ & 0,13 \\
Qtdade. de enxofre absorvida $\left(\mathrm{mg} \mathrm{planta}^{-1}\right)$ & $10,9 \mathrm{a}$ & $9,8 \mathrm{ab}$ & $8,8 \mathrm{~b}$ & 1,5 \\
Concentração de boro $\left(\mathrm{g} \mathrm{kg}^{-1}\right)$ no MS $\left.^{-1}\right)$ & $34,30 \mathrm{a}$ & $37,12 \mathrm{a}$ & $34,66 \mathrm{a}$ & 2,92 \\
Qtdade. de boro absorvida $\left(\mathrm{mg} \mathrm{planta}^{-1}\right)$ & $0,189 \mathrm{a}$ & $0,185 \mathrm{a}$ & $0,160 \mathrm{a}$ & 0,03 \\
Qtdade. de cobre absorvida $\left(\mathrm{mg} \mathrm{planta}^{-1}\right)$ & $0,13 \mathrm{c}$ & $0,33 \mathrm{a}$ & $0,25 \mathrm{~b}$ & 0,07 \\
\hline
\end{tabular}

Médias seguidas de mesma letra em cada linha não diferem entre si pelo teste de Tukey $(\alpha=0,05)$ 